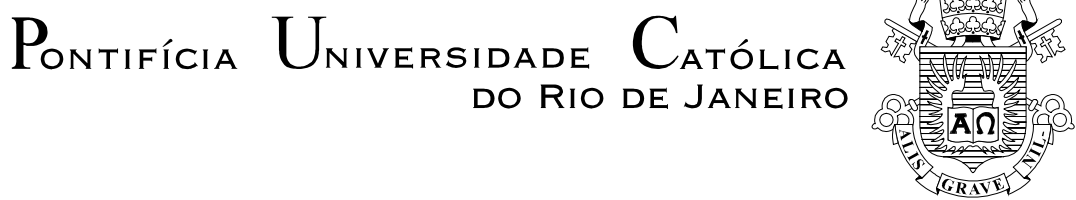

Napoleão Luiz Costa da Silva

Três Ensaios em Desenvolvimento Econômico

Tese apresentada ao programa de Pós-Graduação em Economia do Departamento de Economia da PUC-Rio como parte dos requisitos parciais para obtenção do título de Doutor em Economia.

Orientador: Prof. Eduardo Zilberman

Rio de Janeiro Dezembro de 2016 
Pontifícia Universidade Católica $_{\text {Do Rio de Janeiro }}$

Napoleão Luiz Costa da Silva

\section{Três Ensaios em Desenvolvimento Econômico}

Tese apresentada como requisito parcial para obtenção do título de Doutor pelo Programa de Pós-Graduação em Economia da PUC-Rio. Aprovada pela Comissão Examinadora abaixo assinada.

Prof. Eduardo Zilberman

Orientador

Departamento de Economia - PUC-Rio

Prof. Juliano Assunção

Departamento de Economia - PUC-Rio

Prof. Gabriel Lopes de Ulyssea Departamento de Economia - PUC-Rio

Prof. Carlos Henrique Leite Corseuil IPEA

Prof. Felipe Saraiva lachan FGV - EPGE

Prof. Monica Herz

Coordenadora do Centro de Ciências Sociais - PUC-Rio

Rio de Janeiro, 19 de dezembro 2016 
Todos os direitos reservados. É proibida a reprodução total ou parcial do trabalho sem autorização do autor, do orientador e da universidade.

\section{Napoleão Luiz Costa da Silva}

Bacharel em Economia pela Universidade Federal do Rio de Janeiro em 1995 e Mestre em Economia pela Universidade Federal do Rio de Janeiro em 1998.

Ficha Catalográfica

Silva, Napoleão Luiz Costa da

Três ensaios em desenvolvimento econômico / Napoleão Luiz Costa da Silva; orientador: Eduardo Zilberman. - 2016.

$131 \mathrm{f.} ; 30 \mathrm{~cm}$

Tese (doutorado) - Pontifícia Universidade Católica do Rio de Janeiro, Departamento de Economia, 2016.

Inclui bibliografia

1. Economia - Teses. 2. Fricções financeiras. 3. PIB per capita. 4. Escolha ocupacional. I. Zilberman, Eduardo. II. Pontifícia Universidade Católica do Rio de Janeiro. Departamento de Economia. III. Título.

CDD: 330 


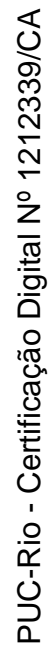

Para meu filho, Mateus. 


\section{Agradecimentos}

À minha esposa, Naiara, pelo suporte ao longo destes anos e pela compreensão do que o doutorado representa para mim. Ao meu filho, Mateus, por todo o amor e carinho.

Aos meus pais, José Siqueira e Maria das Graças, pelo amor, apoio, compreensão, carinho e por sempre acreditarem em mim. Aos meus irmãos, Jasy, José (in memorian) e Michele, pelo amor e apoio.

Ao meu orientador, Eduardo Zilberman, pelo apoio e pelos ensinamentos que possibilitaram a conclusão desta tese.

Aos professores do Departamento de Economia da PUC-Rio pela excelência de seus cursos.

Ao professor Juliano Assunção pelo apoio e pelos ensinamentos que contribuíram fortemente para minha formação e para a conclusão de minha tese.

Aos meus amigos, Ricardo Masini e André Vilela, por todo apoio e camaradagem que foram fundamentais para a minha caminhada no doutorado.

Ao IPEA por decidir investir em mim por meio da licença para capacitação e pelo suporte financeiro.

A Capes pelo apoio financeiro. 


\section{Resumo}

Silva, Napoleão Luiz Costa da; Zilberman, Eduardo (Orientador). Três Ensaios em Desenvolvimento Econômico. Rio de Janeiro, 2016. 131p. Tese de Doutorado - Departamento de Economia, Pontifícia Universidade Católica do Rio de Janeiro.

Esta tese é composta de quatro capítulos sobre a relação entre Crédito e Desenvolvimento Econômico. No primeiro capítulo descrevemos os conceitos, relações e mecanismos utilizados nos demais capítulos. No segundo capítulo avaliamos o impacto de reduções em três diferentes restrições financeiras sobre o PIB per capita no Brasil. Para tanto, utilizamos uma versão do modelo de crescimento neoclássico com agentes heterogêneos e três fricções financeiras. O modelo é calibrado para a economia brasileira em 2009 e fazemos exercícios de simulação. No primeiro exercício, uma redução do custo de participação no mercado de crédito, que permitiria que o percentual de firmas com crédito na economia fosse igual à média dos países desenvolvidos, geraria um aumento no PIB per capita de 3,6\%. No segundo exercício, uma redução do custo de monitoramento, que permitiria que o spread na economia fosse igual ao spread médio nos países desenvolvidos, geraria uma elevação no PIB per capita de 1,7\%. No terceiro exercício avaliamos um relaxamento nas restrições de endividamento. Os resultados mostram que a redução dos colaterais no Brasil para o nível dos países desenvolvidos elevaria o PIB per capita em 12\%. No terceiro capítulo buscamos analisar os efeitos macroeconômicos do aprofundamento do crédito com recursos livres no Brasil no período 2001-2011. Em termos mais específicos, avaliamos os impactos do aumento do crédito sobre o PIB per capita. Para tanto, utilizamos uma versão do modelo de crescimento neoclássico com agentes heterogêneos, restrições de crédito e escolha ocupacional, calibrado para a economia brasileira em 2001 e simulamos, no modelo, o aumento do crédito com recursos livres ocorrido no período. No exercício realizado, o aumento no crédito com recursos livres para as firmas de 10\%, em 2001, para 15\% do PIB em 2011, gerou um aumento de 1,5\% no PIB per capita no período. No quarto capítulo, nosso objetivo é avaliar o impacto do aumento do crédito no Brasil no período 2004-2008 sobre o PIB per capita, com a utilização do modelo de Lloyd-Ellis e Bernhardt (2000). Assim podemos comparar os resultados desse modelo com os resultados do modelo utilizado no terceiro capítulo. Na implementação do modelo, utilizamos uma abordagem mista de estimação e calibração para a economia brasileira em 2004. No exercício realizado, o aumento no acesso ao crédito elevou o PIB per capita em 2\% entre 2004 e 2008.

\section{Palavras-chave}

Fricções financeiras; PIB per capita; escolha ocupacional. 


\section{Abstract}

Silva, Napoleão Luiz Costa da; Zilberman, Eduardo (Advisor). Three Essays in Development Economics. Rio de Janeiro, 2016. 131p. Tese de Doutorado - Departamento de Economia, Pontifícia Universidade Católica do Rio de Janeiro.

This thesis is composed of four chapters on the relationship between Credit and Development Economics. In the first chapter we describe the concepts, relationships and mechanisms used in the other chapters. In the second chapter we evaluated the impact of reductions in three different financial constraints on GDP per capita in Brazil. To do so, we use a version of the neoclassical growth model with heterogeneous agents and three financial frictions. The model is calibrated for the Brazilian economy in 2009 and we do simulation exercises. In the first exercise, a reduction in the cost of participation in the credit market, which would allow the percentage of firms with credit in the economy to be equal to the average of the developed countries, would generate an increase in GDP per capita of 3.6\%. In the second exercise, a reduction in the cost of monitoring, which would allow the spread in the economy to be equal to the average spread in developed countries, would generate a rise in GDP per capita of $1.7 \%$. In the third exercise we evaluated a relaxation in the borrowing constraint. The results show that the reduction of collaterals in Brazil to the level of developed countries would raise GDP per capita by $12 \%$. In the third chapter we seek to analyze the macroeconomic effects of the deepening of credit with free resources in Brazil in the period 2001-2011. In more specific terms, we evaluate the impacts of credit growth on GDP per capita. To do so, we used a version of the neoclassical growth model with heterogeneous agents, credit restrictions and occupational choice, calibrated for the Brazilian economy in 2001 and simulated in the model the increase in credit with free resources occurred in the period. In the exercise, the increase in free resources credit for firms from 10\% in 2001 to 15\% of GDP in 2011 generated a $1.5 \%$ increase in GDP per capita in the period. In the fourth chapter, our objective is to evaluate the impact of the increase of credit in Brazil in the period 20042008 on GDP per capita, using the model of Lloyd-Ellis and Bernhardt (2000). Thus we can compare the results of this model with the results of the model used in the third chapter. In the implementation of the model, we used a mixed approach of estimation and calibration for the Brazilian economy in 2004. In the exercise carried out, the increase in access to credit raised GDP per capita by 2\% between 2004 and 2008.

\section{Keywords}

Financial frictions; GDP per capita; occupational choice. 


\section{Sumário}

1 Introdução 13

2 Desenvolvimento financeiro, crescimento e renda per capita 20

2.1 Introdução 20

2.2 O conceito de desenvolvimento financeiro 21

2.3 A mensuração do nível de desenvolvimento financeiro de um país 23

2.4 Desenvolvimento financeiro no Brasil 24

2.5 Desenvolvimento financeiro, crescimento e nível de renda per $\begin{array}{ll}\text { capita } & 27\end{array}$

2.5.1 Desenvolvimento financeiro, misallocation e renda per capita 28

3 Restrições financeiras e o PIB per capita no Brasil 31

3.1 Introdução 31

3.2 Revisão da literatura 35

$\begin{array}{lll}3.3 & \text { Modelo } & 37\end{array}$

3.4 Calibração 50

3.5 Exercícios realizados e resultados 53

3.5.1 Redução no custo de participação no mercado de crédito 53

3.5.2 Relaxamento da restrição de endividamento 55

3.5.3 Redução no custo de monitoramento 56

3.5.4 Decomposição da taxa de crescimento do PIB per capita 58

$\begin{array}{lll}3.6 & \text { Conclusão } & 60\end{array}$

4 Impactos macroeconômicos do aprofundamento do crédito no Brasil: o período 2001-2011 61

4.1 Introdução 61

$\begin{array}{lll}4.2 & \text { Revisão da literatura } & 68\end{array}$

$\begin{array}{lll}4.3 & \text { Modelo } & 70\end{array}$

$\begin{array}{lll}4.4 & \text { Calibração } & 75\end{array}$

$\begin{array}{lll}4.5 & \text { Exercícios realizados e resultados } & 78\end{array}$

4.5.1 Efeitos do aumento do crédito para as firmas $\quad 78$

4.5.2 Efeitos do aumento do crédito para as firmas e para o
consumidor

$\begin{array}{lll}4.6 & \text { Conclusão } & 85\end{array}$

5 Restrições de crédito sobre as firmas, PIB per capita e o percentual de empresários no Brasil: o período 2004-2008 86

5.1 Introdução 86

$\begin{array}{lll}5.2 & \text { Revisão da literatura } & 90\end{array}$

$\begin{array}{lll}5.3 & \text { Modelo } & 91\end{array}$

5.3.1 Regime sem acesso a crédito 93

5.3.1.1 A partição do espaço (b,x) segundo a ocupação no regime sem
crédito

5.3.2 Regime com acesso a crédito 96

$\begin{array}{lll}\text { 5.3.3 Equilíbrio competitivo } & 98\end{array}$ 
5.4 Estimação/calibração do modelo $\quad 99$

5.4.1 Estimação com microdados 100

5.4.1.1 Base de dados 100

5.4.1.2 Estimação 100

5.4.2 Calibração 102

5.5 Exercícios realizados e resultados 103

5.5.1 Efeitos sobre o PIB per capita com calibrações alternativas 105

5.5.2 Efeitos sobre as condições de escolha ocupacional 106

$\begin{array}{lll}5.6 & \text { Conclusão } & 110\end{array}$

6 Conclusão 111

$7 \quad$ Referências bibliográficas 113

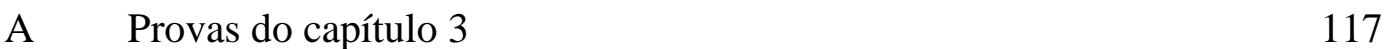

B $\quad$ Método de solução numérica do modelo do capítulo 4

C $\quad$ Construção do índice de riqueza 125

D Identificação do modelo do capítulo 5 


\section{Lista de figuras}

3.1 Firmas com crédito, colaterais requeridos (\% do empréstimo) e spread da taxa de juros

3.2 Redução do custo de participação no mercado de crédito $(\psi)$ : efeitos sobre PIB per capita, spread da taxa de juros, percentual de firmas com crédito e taxa de inadimplência

3.3 Relaxamento da restrição de endividamento $(\lambda)$ : efeitos sobre PIB per capita, spread da taxa de juros, percentual de firmas com crédito e taxa de inadimplência

3.4 Redução no custo de monitoramento $(\chi)$ : efeitos sobre PIB per capita, spread da taxa de juros, percentual de firmas com crédito e taxa de inadimplência

4.1 Crédito privado como proporção do PIB 62

4.2 Crédito privado com recursos livres como proporção do PIB 62

4.3 Crédito privado com recursos livres e PIB per capita 65

$\begin{array}{lll}4.4 & \text { Timing das decisões } & 73\end{array}$

4.5 Elevação do crédito para as firmas: trajetória do parâmetro que controla a restrição de crédito para as firmas (lambda), e trajetória do crédito (modelo e dados)

4.6 Elevação do crédito para as firmas: efeitos sobre PIB per capita, consumo e TFP

4.7 Elevação do crédito para as firmas: efeitos sobre salários, quantidade de trabalho, taxa de juros e estoque de capital

4.8 Elevação do crédito para firmas e consumidores: trajetória dos parâmetros que controlam as restrições de crédito para as firmas (lambda) e para os consumidores (b), e trajetória do crédito para firmas e para consumo (modelo e dados)

4.9 Elevação do crédito para firmas e consumidores: efeitos sobre PIB per capita, consumo e TFP

4.10 Elevação do crédito para firmas e consumidores: efeitos sobre salários, quantidade de trabalho, taxa de juros e estoque de capital

5.1 Crédito privado com recursos livres como proporção do PIB 
5.2 Crédito para as firmas com recursos livres e percentual de empresários na economia

5.3 Mapa de escolha ocupacional 95

5.4 Aumento do percentual da população com acesso a crédito: efeitos sobre o percentual de empresários e sobre o PIB per capita

5.5 Aumento do percentual da população com acesso a crédito: efeitos sobre o PIB per capita, com calibrações para 2004, 2005 e 2006

5.6 Aumento do percentual da população com acesso a crédito: efeitos sobre o PIB per capita com calibrações para 2004, 2005 e 2006

5.7 Mapas de escolha ocupacional para 2004 e para 2008

5.8 Regiões de mudança de ocupação em 2004 e 2008

5.9 Probabilidade de ser empresário dada a riqueza em 2004 e $2008 \quad 109$ 


\section{Lista de tabelas}

2.1 Decomposição do spread bancário em 2009 (\%) 26

3.1 Parâmetros do modelo $\quad 51$

3.2 Ajuste do modelo $\quad 52$

3.3 Decomposição da taxa de crescimento do PIB per capita 59

$\begin{array}{lll}4.1 & \text { Parâmetros do modelo } & 77\end{array}$

$\begin{array}{lll}4.2 & \text { Ajuste do modelo } & 78\end{array}$

$\begin{array}{lll}5.1 & \text { Parâmetros estimados } & 102\end{array}$

$\begin{array}{lll}5.2 & \text { Parâmetros calibrados } & 103\end{array}$

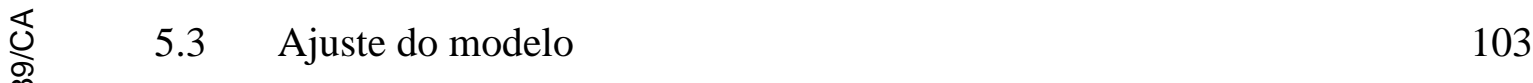

$\begin{array}{lll}5.4 & \text { Parâmetros estimados } & 108\end{array}$

C.1 Análise de componentes principais para construção do índice de $\begin{array}{ll}\text { riqueza } & 126\end{array}$

$\begin{array}{lll}\text { C.2 Variáveis utilizadas e respectivos pesos } & 127\end{array}$ 


\section{Introdução}

Existe uma extensa literatura sobre a relação entre o setor financeiro da economia e o crescimento econômico. Esta literatura mostra que existe evidência substancial de uma relação positiva entre o desenvolvimento financeiro e o crescimento econômico (Levine, 2005). Então, sistemas financeiros que funcionam muito bem desempenham um papel independente na promoção do crescimento econômico de longo prazo. A evidência empírica aponta que economias com sistemas financeiros bem desenvolvidos tendem a crescer mais rapidamente sobre um período de tempo mais longo. Além disso, este é um efeito causal (Demirguç-Kunt e Levine, 2008).

Levine (2005) ressalta que o sistema financeiro afeta o crescimento principalmente por meio de seu efeito sobre a alocação das poupanças da economia, e não por meio de seu efeito sobre a taxa de poupança agregada. Então, quando o sistema financeiro funciona adequadamente na identificação e no financiamento das firmas com os melhores projetos, e não busca financiar as firmas com fortes conexões políticas, isto melhora a alocação do capital e eleva o crescimento econômico. Este tipo de sistema financeiro promove a entrada de novas firmas mais produtivas e força a saída de firmas menos eficientes. Além disso, o sistema expande as oportunidades econômicas, de tal forma que a alocação do crédito (e desse modo das oportunidades) é menos dependente da riqueza acumulada e mais ligada ao valor do projeto.

Contudo, quando o sistema financeiro desempenha suas funções de forma deficiente, ele tende a prejudicar o crescimento econômico e a reduzir as oportunidades na economia. Neste sentido, se o sistema financeiro simplesmente coleta fundos e os repassa para os indivíduos mais ricos (com ativos que podem ser dados em garantia dos empréstimos) e para aqueles com conexões políticas, isto reduz o crescimento econômico e impede que muitos empreendedores em potencial, altamente habilidosos, consigam implementar seus projetos.

Temos que a evidência sobre o papel do sistema financeiro no desenvolvimento econômico é substancial. Contudo, existem sérios problemas 
associados com a mensuração da qualidade do funcionamento do sistema financeiro de um país. Não existem medidas adequadas, ao longo dos países e ao longo do tempo, do grau em que os sistemas financeiros exercem as seguintes funções:

a) melhoria da qualidade da informação sobre as firmas com consequente aumento da eficiência na alocação de recursos.

b) governança corporativa sobre as firmas que recebem empréstimos.

c) fornecimento de mecanismos efetivos para diversificar riscos.

d) mobilização das poupanças de poupadores dispersos para que estes recursos possam ser alocados para os projetos mais promissores na economia.

e) facilitar as transações.

Neste caso, os pesquisadores têm utilizado uma abordagem mais prática, onde o grau de desenvolvimento do sistema financeiro de um país é associado à capacidade do sistema de reduzir os efeitos distorcivos gerados pelas imperfeições do mercado financeiro (informação imperfeita, “limited enforcement” e custos de transação no mercado de crédito).

Temos que, na prática, os mercados financeiros são imperfeitos. Adquirir e processar informação sobre investimentos potenciais é custoso. Além disso, existem custos e incertezas associados com a elaboração, interpretação e o poder de forçar o cumprimento dos contratos (grau de “enforcement”). Também existem custos associados com a transação de bens, serviços e instrumentos financeiros. Essas imperfeições de mercado prejudicam o fluxo de poupanças de uma economia para os indivíduos mais produtivos, com melhores projetos, o que prejudica o crescimento econômico.

Em termos mais específicos, podemos dizer que o desenvolvimento financeiro ocorre quando os instrumentos financeiros e os intermediários reduzem fortemente os efeitos da informação imperfeita, do "limited enforcement" e dos custos de transação na economia. Por exemplo, a criação de registros de crédito tende a melhorar a aquisição e disseminação de informação sobre potenciais tomadores de empréstimos, melhorando a alocação de recursos com efeitos positivos sobre o crescimento econômico.

Temos que a redução dos custos de obtenção de informações sobre os tomadores de empréstimos permite reduzir os "spreads" cobrados. Isto permite elevar a eficiência do sistema financeiro. Além disso, o aumento no grau de 
“enforcement” dos contratos, com a consequente redução dos colaterais requeridos nos empréstimos, permite elevar o grau de endividamento dos agentes, elevando o aprofundamento financeiro. Por último, a redução dos custos de transação no mercado de crédito permite elevar o grau de acesso da população aos serviços financeiros. Neste caso, podemos utilizar o "spread" da taxa de juros, o nível de endividamento do setor privado e o grau de acesso a serviços financeiros como medidas das diferentes dimensões do desenvolvimento financeiro de um país.

Desse modo, para mensurar a qualidade do sistema financeiro de um país utilizamos a metodologia descrita em Cihák e outros (2012) ${ }^{1}$. Esta metodologia utiliza medidas de três características das instituições financeiras ${ }^{2}$ : a) o tamanho das instituições financeiras (aprofundamento financeiro), b) o grau no qual os indivíduos podem usar e realmente usam instituições financeiras (acesso) e c) a eficiência das instituições financeiras na provisão de serviços financeiros (eficiência). Estas medidas podem ser usadas para caracterizar e comparar os sistemas financeiros de diferentes países. A medida de aprofundamento financeiro de um país que utilizamos neste trabalho é o crédito privado como proporção do PIB. Para medir o grau de acesso a serviços financeiros usamos o percentual de firmas com acesso a um empréstimo bancário ou uma linha de crédito. Além disso, para medir a eficiência na intermediação financeira utilizamos o "spread" da taxa de juros.

Essas três dimensões do desenvolvimento financeiro (aprofundamento, acesso e eficiência) permitem mensurar o grau de desenvolvimento do sistema financeiro brasileiro em relação aos sistemas financeiros dos países desenvolvidos. No Brasil o acesso a serviços financeiros é bem menor do que o acesso nos países desenvolvidos. No país, em 2009, 59\% das firmas tinham acesso a um empréstimo bancário ou uma linha de crédito. Nos países desenvolvidos o percentual médio era de 95\%. O aprofundamento financeiro, no caso brasileiro, também é bem menor do que o dos países desenvolvidos. O crédito privado como percentual do PIB atingiu 46\% no Brasil em 2009 e 113\% em média, nos países de renda elevada. Por último temos que a eficiência do

\footnotetext{
${ }^{1}$ Esta é a metodologia adotada pelo Banco Mundial para avaliar o desenvolvimento financeiro de um país. Neste texto não abordaremos a dimensão da estabilidade do sistema financeiro de um país.

${ }^{2}$ Estas são formadas basicamente por bancos.
} 
sistema financeiro brasileiro é bem menor do que a dos países desenvolvidos. No Brasil, o "spread" da taxa de juros para as firmas é muito elevado em relação à média dos países desenvolvidos (12\% no Brasil e 3\% nos países desenvolvidos). Os indicadores descritos acima mostram que o sistema financeiro brasileiro é bem menos desenvolvido que os sistemas financeiros dos países de renda mais elevada.

Neste trabalho buscamos avaliar os impactos de aumentos no grau de desenvolvimento do sistema financeiro sobre a renda per capita no Brasil. Neste sentido, vamos avaliar o impacto de reduções nas imperfeições no mercado financeiro (reduções no custo de obtenção de informações sobre as firmas, aumentos no limite de endividamento das firmas e redução nos custos de transação no mercado de crédito) que elevam o desenvolvimento financeiro (aumento no acesso a serviços financeiros, elevação do aprofundamento financeiro e aumento da eficiência na intermediação) e desse modo, aumentam a renda per capita do país.

Para tanto, no capítulo 1, detalharemos o conceito de desenvolvimento financeiro e a metodologia adotada para mensurar o grau de desenvolvimento financeiro de um país. Depois abordaremos o grau de desenvolvimento do sistema financeiro brasileiro. Por último, trataremos da relação entre desenvolvimento financeiro, crescimento econômico e renda per capita.

No capítulo 2 analisamos os efeitos de elevações no grau de desenvolvimento do sistema financeiro brasileiro sobre a renda per capita. Neste sentido, estudamos os efeitos de reduções nas fricções financeiras que permitiriam que os níveis de aprofundamento, acesso e de eficiência no Brasil fossem iguais aos níveis médios dos países desenvolvidos. Em termos mais específicos, neste capítulo analisamos os impactos de reduções em cada uma das três fricções financeiras (custo de participação no mercado de crédito, limite de endividamento ou custo de monitoramento) sobre o PIB per capita no Brasil. Para tanto, utilizamos uma versão do modelo de crescimento neoclássico com agentes heterogêneos e três fricções financeiras. O modelo é calibrado para a economia brasileira em 2009 e fazemos exercícios de simulação onde avaliamos os impactos de reduções nas fricções financeiras que elevam o acesso, o aprofundamento e a eficiência. Os resultados mostram que reduções nas fricções financeiras geram impactos expressivos sobre o PIB per capita. 
No primeiro exercício, a redução do custo de participação no mercado de crédito (que eleva o acesso financeiro para o nível dos países desenvolvidos) gera um aumento no PIB per capita de 3,6\%. No segundo exercício, a redução do custo de monitoramento (que eleva a eficiência do sistema para o nível dos países desenvolvidos) gera uma elevação no PIB per capita de 1,7\%. Por último, no terceiro exercício avaliamos um relaxamento nas restrições de endividamento que seria obtido se os colaterais como proporção dos empréstimos no Brasil fossem iguais à média dos países desenvolvidos. Os resultados mostram que a redução dos colaterais no Brasil elevaria o PIB per capita em 12\%.

Desse modo, a restrição financeira com maior impacto sobre o PIB per capita, no caso brasileiro, é o limite de endividamento. Neste sentido, políticas voltadas para a redução das exigências de colaterais e aumento do grau de “enforcement” dos contratos, terão um impacto maior sobre o PIB do que políticas que visem reduzir o spread ou elevar a participação no mercado de crédito. Isto ocorre devido ao fato de que os empresários no Brasil são fortemente restritos por requerimentos de colaterais elevados. Assim uma redução no custo de intermediação somente beneficia um pequeno número de empresários que possuem colaterais suficientes para obter empréstimos.

Vimos que se o grau de aprofundamento financeiro no Brasil fosse igual à média dos países desenvolvidos, a renda per capita seria 12\% maior. Para isto ocorrer, o crédito para as firmas teria que ser elevado de 10\% do PIB para cerca de $45 \%$ do PIB. Então teria que ocorrer um aumento enorme do crédito para as firmas como proporção do PIB para que a renda per capita se elevasse em 12\%.

No capítulo 3 avaliamos os impactos do desenvolvimento financeiro ocorrido no Brasil entre 2001 e 2011. Este desenvolvimento ocorreu, basicamente, devido a um forte aprofundamento financeiro no período, onde o crédito privado como proporção do PIB cresceu bastante. Desse modo, no capítulo 3 buscamos analisar os efeitos macroeconômicos do aprofundamento do crédito com recursos livres ocorrido no Brasil no período 2001-2011. Para tanto, utilizamos uma versão do modelo de crescimento neoclássico com agentes heterogêneos, restrições de crédito e escolha ocupacional, calibrado para a economia brasileira em 2001. Este modelo é muito próximo do modelo utilizado em Bueira e Shin (2013) e nele a imperfeição no mercado de crédito é dada por um limite de endividamento. Esta é a fricção financeira adequada para abordar o aprofundamento de crédito ocorrido 
no período. Além disso, utilizar esta fricção está de acordo com os resultados do segundo capítulo, onde a restrição financeira mais relevante no caso brasileiro é o limite de endividamento. Nós simulamos o aumento do crédito com recursos livres, como proporção do PIB, ocorrido no período. Nossos resultados mostram um impacto pequeno do aumento do crédito para as firmas sobre o PIB per capita. No exercício realizado, o aumento no crédito com recursos livres para as firmas de $10 \%$, em 2001, para 15\% do PIB em 2011, gerou um aumento de 1,5\% no PIB per capita no período. Devemos notar que este pequeno impacto do crédito sobre o PIB per capita está de acordo com o resultado obtido no capítulo 2 com relação ao aprofundamento financeiro. No capítulo 2 vimos que seria necessário um aumento no crédito para as firmas de 35\% do PIB (passar de 10\% para 45\% do PIB) para que o PIB per capita se elevasse em 12\%. No capítulo 3, o aumento no crédito para as firmas de 5\% do PIB (passou de 10\% para 15\% do PIB) gerou um aumento no PIB per capita de 1,5\%.

No capítulo 3, o impacto obtido do aprofundamento financeiro sobre o PIB per capita foi pequeno. Para verificar a consistência desse resultado, no capítulo 4 utilizamos também o modelo de Lloyd-Ellis e Bernhardt (2000) para avaliar o aprofundamento de crédito ocorrido no período. Nesse sentido, analisamos os efeitos do aumento do crédito com recursos livres para as firmas sobre o nível de PIB per capita, no período 2004-2008. Para tanto, utilizamos uma versão do modelo de Lloyd-Ellis e Bernhardt (2000). Na implementação do modelo, utilizamos uma abordagem mista de estimação e calibração para a economia brasileira em 2004. Nós simulamos o aumento do crédito para as firmas, ocorrido no período. Nossos resultados mostram que o aumento do crédito gerou um impacto pequeno sobre o PIB per capita. A expansão do crédito elevou o PIB per capita em 2\% entre 2004 e 2008 no modelo. Este resultado é muito próximo do resultado obtido com o modelo utilizado no capítulo 3.

Em resumo, este trabalho mostra que o grau de desenvolvimento financeiro é importante para explicar o nível de renda per capita no Brasil. Neste sentido, se o grau de aprofundamento financeiro no Brasil se elevasse para o nível dos países desenvolvidos, o PIB per capita se elevaria em 12\%. Além disso, se o nível de acesso financeiro no Brasil fosse igual ao nível dos países desenvolvidos, a renda per capita seria 3,6\% maior. Por último, se o grau de eficiência do sistema 
financeiro brasileiro fosse o mesmo dos países de renda elevada, a renda per capita seria $1,7 \%$ maior.

Este trabalho também mostra que o aprofundamento financeiro ocorrido no Brasil entre 2001 e 2011 gerou um pequeno aumento de 1,5\% na renda per capita. Isto ocorreu devido ao pequeno aumento no crédito para as firmas (de 5\% do PIB) no período, em relação ao que seria necessário para atingir o nível de aprofundamento dos países desenvolvidos (um aumento de 35\% do PIB). 


\section{2 \\ Desenvolvimento financeiro, crescimento e renda per capita}

\section{1}

\section{Introdução}

Existe uma extensa literatura sobre a relação entre o setor financeiro da economia e o crescimento econômico. Esta literatura mostra que existe evidência substancial de uma relação positiva entre o desenvolvimento financeiro e o crescimento econômico (Levine, 2005).

Para mensurar a qualidade do sistema financeiro de um país utilizamos a metodologia descrita em Cihák e outros $(2012)^{3}$. Esta metodologia utiliza medidas de três características das instituições financeiras ${ }^{4}$ : a) o tamanho das instituições financeiras (aprofundamento financeiro), b) o grau no qual os indivíduos podem usar e realmente usam instituições financeiras (acesso) e c) a eficiência das instituições financeiras na provisão de serviços financeiros (eficiência). Estas medidas podem ser usadas para caracterizar e comparar os sistemas financeiros de diferentes países.

Essas três dimensões do desenvolvimento financeiro (aprofundamento, acesso e eficiência) permitem mensurar o grau de desenvolvimento do sistema financeiro brasileiro em relação aos sistemas financeiros dos países desenvolvidos.

Neste capítulo trataremos dos conceitos, das relações e dos mecanismos que serão utilizados neste trabalho. Para tanto, nesta seção 1 fazemos uma introdução. Na seção 2 descreveremos o conceito de desenvolvimento financeiro e na seção 3 a metodologia utilizada para mensurá-lo. Além disso, na seção 4 abordaremos o grau de desenvolvimento do sistema financeiro brasileiro. Por fim,

\footnotetext{
${ }^{3}$ Esta metodologia foi adotada pelo Banco Mundial para avaliar o desenvolvimento financeiro dos países. Neste texto não abordaremos a dimensão da estabilidade do sistema financeiro de um país.

${ }^{4}$ Estas são formadas basicamente por bancos.
} 
trataremos, na seção 5, da relação entre desenvolvimento financeiro, crescimento e nível de renda per capita.

\section{2}

\section{O conceito de desenvolvimento financeiro}

Existe evidência considerável sobre o importante papel do desenvolvimento financeiro no crescimento econômico (Levine, 2005). As economias com níveis mais elevados de desenvolvimento financeiro crescem mais rapidamente e possuem níveis de renda per capita mais elevados. Contudo, existem sérios problemas associados com a mensuração da qualidade do funcionamento do sistema financeiro de um país. Não existem medidas adequadas, ao longo dos países e ao longo do tempo, do grau em que os sistemas financeiros exercem as seguintes funções ${ }^{5}$ :

a) melhoria da qualidade da informação sobre as firmas com consequente aumento da eficiência na alocação de recursos.

b) governança corporativa sobre as firmas que recebem empréstimos.

c) fornecimento de mecanismos efetivos para diversificar riscos.

d) mobilização das poupanças de poupadores dispersos para que estes recursos possam ser alocados para os projetos mais promissores na economia.

e) facilitar as transações.

Neste caso, os pesquisadores têm utilizado uma abordagem mais prática, onde o grau de desenvolvimento do sistema financeiro de um país é associado à capacidade do sistema de reduzir os efeitos distorcivos gerados pelas imperfeições do mercado financeiro (informação imperfeita, "limited enforcement” e custos de transação no mercado de crédito).

Temos que, na prática, os mercados financeiros são imperfeitos. Adquirir e processar informação sobre investimentos potenciais é custoso. Além disso, existem custos e incertezas associados com a elaboração, interpretação e o poder de forçar o cumprimento dos contratos (grau de “enforcement”). Também existem custos associados com a transação de bens, serviços e instrumentos financeiros.

\footnotetext{
${ }^{5}$ Levine (2005) aponta que as variáveis "proxy” empíricas utilizadas para medir estas funções financeiras frequentemente não medem adequadamente os conceitos derivados dos modelos teóricos.
} 
Essas imperfeições de mercado prejudicam o fluxo de poupanças de uma economia para os indivíduos mais produtivos, com melhores projetos, o que prejudica o crescimento econômico.

A existência dessas imperfeições de mercado gera incentivos para o surgimento de contratos e intermediários financeiros. Neste sentido, os indivíduos, visando o lucro, criam produtos financeiros e instituições para reduzir os efeitos dessas imperfeições de mercado. Os governos também fornecem serviços, como o sistema legal e usam bancos públicos visando reduzir as imperfeições no mercado financeiro e melhorar a alocação dos recursos. Algumas economias são relativamente bem sucedidas no desenvolvimento de sistemas financeiros que reduzem esses custos. Outras economias não são tão bem sucedidas, o que prejudica o desenvolvimento econômico.

Em termos mais específicos, podemos dizer que o desenvolvimento financeiro ocorre quando os instrumentos financeiros e os intermediários reduzem fortemente os efeitos da informação imperfeita, do "limited enforcement” e dos custos de transação na economia. Por exemplo, a criação de registros de crédito tende a melhorar a aquisição e disseminação de informação sobre potenciais tomadores de empréstimos, melhorando a alocação de recursos com efeitos positivos sobre o crescimento econômico.

Temos que a redução dos custos de obtenção de informações sobre os tomadores de empréstimos permite reduzir os “spreads” cobrados. Isto permite elevar a eficiência do sistema financeiro. Além disso, o aumento no grau de “enforcement” dos contratos, com a consequente redução dos colaterais requeridos nos empréstimos, permite elevar o grau de endividamento dos agentes, elevando o aprofundamento financeiro. Por último, a redução dos custos de transação no mercado de crédito permite elevar o grau de acesso da população aos serviços financeiros. Neste caso, podemos utilizar o "spread" da taxa de juros, o nível de endividamento do setor privado e o grau de acesso a serviços financeiros como medidas das diferentes dimensões do desenvolvimento financeiro de um país. 


\section{3}

\section{A mensuração do nível de desenvolvimento financeiro de um país}

Neste texto utilizaremos a metodologia descrita em Cihák e outros (2012) para avaliar o desenvolvimento financeiro de um país. Nesta metodologia são mensuradas empiricamente três características importantes dos sistemas financeiros dos países. As dimensões mensuradas dos sistemas financeiros são: a) aprofundamento financeiro, b) acesso ao setor financeiro e c) eficiência do sistema financeiro ${ }^{6}$.

Estas características do sistema financeiro são “proxies” dos serviços fornecidos pelo sistema. Neste sentido, “aprofundamento financeiro” não é uma função primária do sistema financeiro, contudo, ela é uma "proxy" da extensão total dos serviços fornecidos pelo sistema financeiro. Do mesmo modo, as medidas disponíveis para "acesso" não medem diretamente quão bem o sistema financeiro identifica bons investimentos, sem relação aos colaterais dos indivíduos. Contudo, ela fornece uma aproximação da extensão do uso de instituições financeiras e de instrumentos financeiros particulares.

As três dimensões das instituições financeiras são utilizadas para fornecer medidas do conceito de funcionamento dos sistemas financeiros. Temos que as dimensões de aprofundamento financeiro, acesso e eficiência não abrangem todas as características dos sistemas financeiros. Contudo, estas três dimensões são utilizadas como uma base para descrever e comparar sistemas financeiros de países diferentes.

A utilização destas três medidas ressalta a natureza multidimensional dos sistemas financeiros. Temos que sistemas com forte aprofundamento financeiro não necessariamente fornecem alto grau de acesso financeiro. Sistemas financeiros altamente eficientes não são necessariamente mais aprofundados que sistemas menos eficientes. Cada uma destas características está associada com aspectos do desenvolvimento econômico e com políticas específicas do setor financeiro.

\footnotetext{
${ }^{6}$ Cihák e outros (2012) também leva em consideração a dimensão da estabilidade financeira, contudo, neste trabalho não abordaremos esta dimensão.
} 
Aprofundamento financeiro (tamanho)

Para as instituições financeiras, a variável que utilizamos para medir o aprofundamento financeiro é o crédito privado como percentual do PIB. Existe uma literatura extensa demonstrando a ligação entre aprofundamento financeiro, aproximado pelo crédito para o setor privado como proporção do PIB, e o crescimento econômico de longo prazo (Demirguç-Kunt e Levine, 2008).

\section{Acesso financeiro (inclusão)}

Um sistema financeiro que funciona bem, aloca o capital baseado na qualidade esperada do projeto e do empreendedor. Não aloca recursos baseado na riqueza acumulada (colaterais) e nas conexões políticas do empresário. Um sistema financeiro bem desenvolvido que supera as fricções de mercado, fornecerá, mais efetivamente, serviços financeiros para uma proporção bem mais elevada de firmas e famílias na economia. Ele não fornecerá serviços financeiros somente para grandes empresas e indivíduos ricos. Neste caso, para desenvolver “proxies” informativas do desenvolvimento financeiro, é útil ir além do aprofundamento financeiro e também incluir indicadores de acesso financeiro. Ou seja, medidas do grau no qual o público pode acessar serviços financeiros. Neste trabalho, utilizamos como indicador do acesso às instituições financeiras de um país, o percentual de firmas com acesso a uma linha de crédito na economia.

Eficiência financeira

A medida de eficiência financeira é construída para medir o custo de intermediação do crédito. A medida de eficiência para as instituições financeiras que nós utilizamos neste texto é o "spread” da taxa de juros. Ele é definido pela diferença entre a taxa média dos empréstimos e a taxa média de captação dos bancos.

\section{4}

\section{Desenvolvimento financeiro no Brasil}

Essas três dimensões do desenvolvimento financeiro (aprofundamento, acesso e eficiência) permitem mensurar o grau de desenvolvimento do sistema 
financeiro brasileiro em relação aos sistemas financeiros dos países desenvolvidos.

No Brasil o acesso a serviços financeiros é bem menor do que o acesso nos países desenvolvidos. No país, em 2009, 59\% das firmas tinham acesso a um empréstimo bancário ou uma linha de crédito. Nos países desenvolvidos o percentual médio era de 95\%. O acesso a serviços financeiros é determinado principalmente por um custo de participação no mercado de crédito. Este custo inclui custos de transação fixos, tarifas anuais elevadas, requerimentos de documentação e outras barreiras ao acesso encaradas pelas firmas. Segundo Assunção (2013), uma das maiores barreiras que impedem que pequenas firmas tenham acesso a serviços financeiros é a inexistência de agências bancárias em sua região.

O aprofundamento financeiro, no caso brasileiro, também é bem menor do que o dos países desenvolvidos. O crédito privado como percentual do PIB atingiu 46\% no Brasil em 2009 e 113\% em média, nos países de renda elevada. Devido ao “enforcement” limitado dos contratos, o empresário precisa fornecer colaterais ao banco para poder obter empréstimos. Nesse sentido, quanto maior o poder de forçar o cumprimento dos contratos menores são os requerimentos de colaterais ${ }^{7}$. No Brasil os requerimentos de colaterais são bem maiores do que os requerimentos nos países desenvolvidos. O nível de garantias exigidas para as firmas brasileiras foi de 95\% do valor do empréstimo, em média, no ano de 2009. No caso dos países desenvolvidos, o nível médio de colaterais exigidos foi de $50 \%$ do valor do empréstimo. Devemos notar que o nível de colaterais exigidos é um dos principais determinantes do grau de endividamento das firmas e do crédito privado como proporção do PIB. Assim, um aumento no grau de "enforcement" reduz os colaterais requeridos e eleva o aprofundamento financeiro na economia ${ }^{8}$.

Por último, temos que a eficiência do sistema financeiro brasileiro é bem menor do que a dos países desenvolvidos. No Brasil, o “spread” da taxa de juros ${ }^{9}$ para as firmas é muito elevado em relação à média dos países desenvolvidos (12\% no Brasil e 3\% nos países desenvolvidos). O “spread” bancário, líquido de impostos, compreende, basicamente, o lucro e o risco relativos às operações de

\footnotetext{
${ }^{7}$ Dabla-Norris e outros (2015).

${ }^{8}$ Dabla-Norris e outros, (2015) e Buera e Shin (2013).

${ }^{9} \mathrm{O}$ "spread" é definido como a diferença entre a taxa cobrada nos empréstimos e a taxa de captação dos recursos.
} 
crédito. Na metodologia utilizada pelo Banco Central do Brasil (Bacen), o “spread” é decomposto em cinco componentes ${ }^{10}$ :

a) custo administrativo: compreende os custos com insumos utilizados pela indústria bancária (capital físico, trabalho e recursos operacionais),

b) inadimplência: equivale a $20 \%$ das provisões para devedores duvidosos, calculadas de acordo com as regras de provisionamento estabelecidas pelo Conselho Monetário Nacional,

c) custo do compulsório: corresponde ao custo de oportunidade que os bancos incorrem em deixar parte dos depósitos à vista e a prazo depositados no Bacen, com rendimento inferior ao que obteriam se pudessem emprestar os recursos,

d) tributos e taxas: incluem tributos indiretos como o IOF, PIS, COFINS e ISS, além do imposto de renda e da contribuição social sobre o lucro líquido,

e) margem líquida: corresponde à diferença entre o "spread" total e a soma dos quatro componentes anteriores. Ela inclui o lucro do banco e demais fatores não considerados nos itens anteriores (como erros de mensuração).

A tabela abaixo mostra a decomposição do "spread” no Brasil para o ano de 2009.

Tabela 2.1: Decomposição do spread bancário em 2009 (\%)

\begin{tabular}{|l|c|}
\hline & Decomposição do spread bancário em 2009 (\%) \\
\hline 1 - spread total & 100,0 \\
\hline 2 - custo administrativo & 11,3 \\
\hline 3 - inadimplência & 28,8 \\
\hline 4 - compulsório e outros & 4,0 \\
\hline 5 - margem bruta & 55,9 \\
\hline 6 - impostos diretos & 22,4 \\
\hline 7 - margem líquida & 33,5 \\
\hline
\end{tabular}

Fonte: BACEN.

Na tabela 2.1 podemos notar que o maior componente do "spread” total é a margem líquida que representa 33,5\% do mesmo. O custo da inadimplência é o segundo maior componente e corresponde a $28,8 \%$ do "spread" total. Os impostos

\footnotetext{
${ }^{10}$ Afonso e outros (2009).
} 
indiretos também representam uma parcela elevada do "spread” total $(22,4 \%)$. Estes três componentes correspondem a cerca de 85\% do "spread” total.

Os indicadores sobre acesso, aprofundamento e eficiência, descritos acima, mostram que o sistema financeiro brasileiro é bem menos desenvolvido que os sistemas financeiros dos países de renda mais elevada.

\section{5}

\section{Desenvolvimento financeiro, crescimento e nível de renda per capita}

Existe uma extensa literatura sobre a relação entre o setor financeiro da economia e o crescimento econômico. Esta literatura mostra que existe evidência substancial de uma relação positiva entre o desenvolvimento financeiro e o crescimento econômico (Levine, 2005). Então, sistemas financeiros que funcionam muito bem desempenham um papel independente na promoção do crescimento econômico de longo prazo. A evidência empírica aponta que economias com sistemas financeiros bem desenvolvidos tendem a crescer mais rapidamente sobre um período de tempo mais longo. Além disso, este é um efeito causal (Demirguç-Kunt e Levine, 2008).

Levine (2005) ressalta cinco canais por meio dos quais o setor financeiro afeta o crescimento. O sistema financeiro afeta o crescimento principalmente por meio de seu efeito sobre a alocação das poupanças da economia, e não por meio de seu efeito sobre a taxa de poupança agregada. Então, quando o sistema financeiro funciona adequadamente na identificação e no financiamento das firmas com os melhores projetos, e não busca financiar as firmas com fortes conexões políticas, isto melhora a alocação do capital e eleva o crescimento econômico. Este tipo de sistema financeiro promove a entrada de novas firmas mais produtivas e força a saída de firmas menos eficientes. Além disso, o sistema expande as oportunidades econômicas, de tal forma que a alocação do crédito (e desse modo das oportunidades) é menos dependente da riqueza acumulada e mais ligada ao valor do projeto. Sistemas financeiros bem desenvolvidos também melhoram a governança das firmas, o que reduz o desperdício e as fraudes, aumentando a eficiência no uso dos recursos escassos. Os sistemas financeiros também facilitam a administração dos riscos e desse modo possibilitam o 
financiamento de empreendimentos com retornos mais elevados com efeitos positivos sobre o crescimento. Além disso, ao mobilizar as poupanças da sociedade, o sistema financeiro torna possível explorar economias de escala na utilização dos recursos disponíveis. Por último, quando o sistema financeiro reduz os custos de transação, isto facilita as transações e a especialização (que é fundamental para a inovação tecnológica).

Contudo, quando o sistema financeiro desempenha estas funções de forma deficiente, ele tende a prejudicar o crescimento econômico, reduzir as oportunidades e desestabilizar a economia. Neste sentido, se o sistema financeiro simplesmente coleta fundos e os repassa para os indivíduos mais ricos (com ativos que podem ser dados em garantia dos empréstimos) e para aqueles com conexões políticas, isto reduz o crescimento econômico e impede que muitos empreendedores em potencial, altamente habilidosos, consigam implementar seus projetos. Além disso, se as instituições financeiras falham em exercer uma governança corporativa de qualidade sobre as firmas que elas financiam, fica mais fácil para os administradores implementarem projetos que os beneficiam em vez de beneficiar as firmas e a economia como um todo.

\subsection{1}

\section{Desenvolvimento financeiro, misallocation e renda per capita}

Vimos que existe evidência empírica substancial do efeito do desenvolvimento financeiro sobre a renda per capita. Nesta subseção explicitaremos o mecanismo de transmissão dessa relação que utilizaremos ao longo deste trabalho. Basicamente, um aumento no desenvolvimento financeiro, gerado por reduções nas fricções financeiras, melhora a eficiência na alocação de recursos na economia (reduz a “misallocation” dos fatores de produção). Isto permite elevar a produtividade total dos fatores (TFP) e a renda per capita ${ }^{11}$.

Recentemente, a literatura tem adotado uma nova perspectiva com relação às diferenças na TFP e na renda per capita entre países. Esta linha de pesquisa parte do argumento de que em uma economia com unidades de produção heterogêneas, a TFP agregada e a renda per capita dependem não somente das

\footnotetext{
${ }^{11}$ Vide Buera e Shin(2013) e Dabla-Norris e outros(2015).
} 
TFPs das unidades de produção individuais, mas também de como os insumos são alocados entre estas unidades de produção. Neste caso, a TFP e a renda per capita podem ser baixas porque os insumos são alocados de forma ineficiente (neste caso ocorre "misallocation”) entre unidades de produção heterogêneas ${ }^{12}$.

Vários estudos apontam que a “misallocation” dos fatores de produção entre firmas com produtividades diferentes é responsável por grande parte das diferenças observadas na renda per capita entre os países em desenvolvimento e os países desenvolvidos ${ }^{13}$. A “misallocation” é gerada por imperfeições de mercado que distorcem a alocação dos fatores produtivos entre as firmas heterogêneas.

Dentre as imperfeições de mercado que afetam a renda per capita, podemos destacar as imperfeições geradas por distorções no mercado de crédito. Vários estudos apontam que as imperfeições no mercado de crédito são importantes para explicar parte da "misallocation” e são responsáveis por boa parte das diferenças na renda per capita entre países desenvolvidos e em desenvolvimento ${ }^{14}$.

Neste sentido, nos próximos capítulos utilizaremos um mecanismo que leva em conta reduções na "misallocation” para avaliar os impactos de reduções nas fricções financeiras sobre a renda per capita. Neste caso, todos os modelos utilizados nos próximos capítulos possuem um mecanismo onde as reduções nas fricções financeiras para as firmas elevam a TFP e o PIB. Nestes modelos, as restrições financeiras para as firmas impedem que elas (ou a maioria delas) escolham o nível de capital que maximiza o lucro irrestrito. Dado que o capital contratado depende dos ativos da firma, teremos nesta economia firmas muito produtivas, com ativos baixos, que contratam pouco capital e firmas pouco produtivas, com ativos elevados, que contratam muito capital. Isto gera uma alocação ineficiente do capital e reduz a TFP. Quando se reduz as fricções financeiras, parte do capital flui das firmas menos produtivas para as mais produtivas, o que eleva a TFP e o PIB.

Nos modelos, as restrições financeiras para as firmas também impedem que indivíduos com alta habilidade e ativos baixos se tornem empresários. Isto

\footnotetext{
${ }^{12}$ Vide Restuccia(2013).

${ }^{13}$ Vide Restuccia(2013).

${ }^{14}$ Vide Buera e Shin(2013) e Dabla-Norris e outros(2015).
} 
gera uma alocação ineficiente do talento empresarial e reduz a TFP. O relaxamento das restrições financeiras permite que indivíduos de alta habilidade e ativos baixos se tornem empresários o que eleva adicionalmente a TFP e o produto. 
3

Restrições financeiras e o PIB per capita no Brasil

\section{1}

\section{Introdução}

As restrições financeiras sobre as firmas brasileiras são muito elevadas em relação às economias avançadas. Além disso, em certos aspectos, as restrições do mercado de crédito sobre as firmas brasileiras são mais elevadas do que as restrições verificadas em média nos países em desenvolvimento.

Neste trabalho, nosso interesse repousa em três restrições específicas geradas por fricções financeiras. A primeira corresponde às restrições no acesso a serviços financeiros (geradas por um custo de participação no mercado de crédito) que impedem que parte das firmas tenha acesso a um empréstimo. A segunda corresponde aos requerimentos de colaterais para empréstimos (gerados pelo "limited commitment”) que impõem restrições de endividamento para as firmas. A terceira corresponde ao "spread" da taxa de juros (que é gerado, entre outras coisas, pela informação assimétrica e pelos custos de monitoramento).
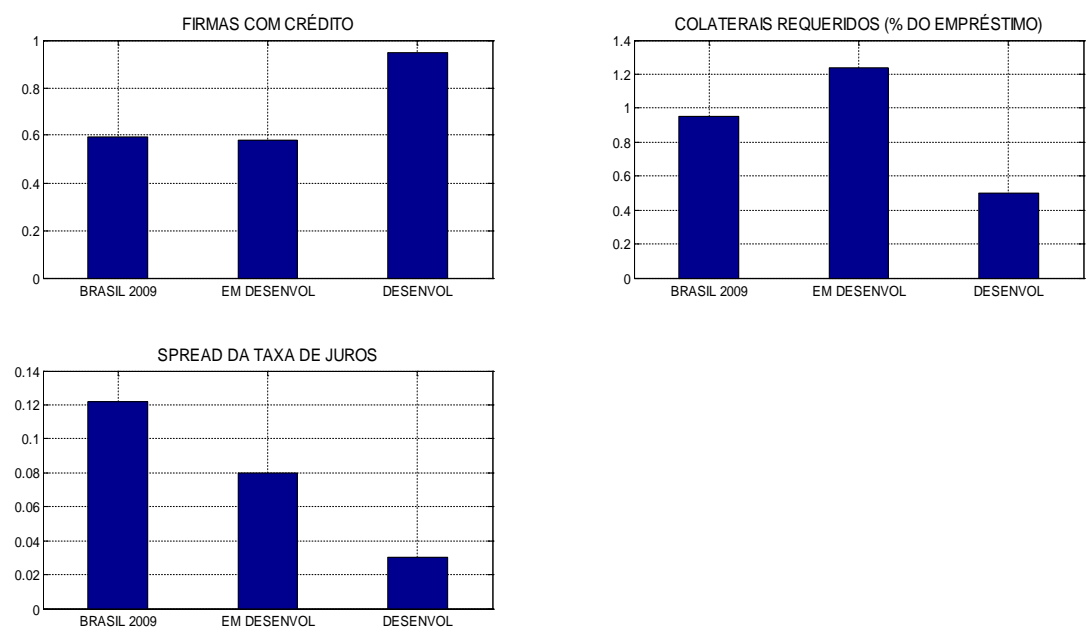

Figura 3.1: Firmas com crédito, colaterais requeridos (\% do empréstimo) e spread da taxa de juros. 
Os dados são referentes ao Brasil em 2009, a média dos países em desenvolvimento (em desenvol), e a média dos países desenvolvidos (desenvol). Fonte: World Bank Enterprise Surveys e BACEN.

No Brasil, cerca de 59\% das firmas têm acesso a um empréstimo bancário ou uma linha de crédito. Nos países desenvolvidos o percentual médio é de 95\% e a média dos países em desenvolvimento é de 58\%. Neste aspecto o Brasil está próximo dos países em desenvolvimento, contudo, está muito abaixo dos países desenvolvidos. Os requerimentos de colaterais para empréstimos, que impõem restrições de endividamento sobre as firmas, são bem menores no Brasil (95\% do valor do empréstimo) quando comparados à média dos países em desenvolvimento (124\% do valor do empréstimo). Por outro lado, os requerimentos de colaterais no Brasil são bem maiores do que a média dos países desenvolvidos (50\% do valor do empréstimo). O “spread” da taxa de juros no Brasil (diferença entre as taxas de empréstimo e de captação de recursos) é muito elevado em relação à média dos países em desenvolvimento. Além disso, o “spread” é extremamente elevado em relação à média dos países desenvolvidos, como podemos observar na figura 3.1.

Devemos notar que reduções nas fricções financeiras, que determinam as restrições no mercado de crédito, podem gerar impactos significativos sobre o PIB per capita. Neste contexto, o objetivo do nosso trabalho é avaliar o impacto de reduções em três diferentes restrições financeiras sobre o PIB per capita no Brasil. Em termos mais específicos, nossa meta principal é avaliar qual das três fricções financeiras (custo de participação no mercado de crédito, limite de endividamento ou custo de monitoramento) é a mais importante para afetar o PIB per capita no Brasil. Para realizar nosso objetivo utilizamos a estrutura teórica desenvolvida em Dabla-Norris e outros (2015). Esta estrutura consiste de uma versão do modelo de crescimento neoclássico com agentes heterogêneos e três fricções financeiras. O modelo é calibrado para a economia brasileira e fazemos exercícios de simulação onde avaliamos os impactos de reduções nas fricções financeiras no mercado de crédito com recursos livres ${ }^{15}$. A contribuição do trabalho para a literatura no

\footnotetext{
${ }^{15}$ Estes recursos são emprestados com taxas de juros livremente negociadas no mercado. Então não avaliaremos o impacto do crédito direcionado, que é obtido com taxas de juros subsidiadas. Isto significa, basicamente, que não avaliaremos os efeitos do crédito fornecido pelo Banco Nacional de Desenvolvimento Econômico e Social (BNDES). Para avaliar os efeitos do crédito subsidiado seria necessário modelar a economia com um agente que empresta com taxas de juros
} 
Brasil é utilizar uma modelagem que permite avaliar, em uma mesma estrutura, os impactos de reduções em várias fricções financeiras sobre a TFP e o PIB per capita.

Nós utilizamos o modelo teórico de Dabla-Norris e outros (2015) que consiste de uma versão do modelo de crescimento neoclássico com famílias heterogêneas e firmas heterogêneas. As famílias são heterogêneas na quantidade de ativos que possuem e no nível de habilidade (que denominamos aqui de habilidade empresarial). O modelo inclui escolha ocupacional, neste caso, em cada período, os indivíduos escolhem entre trabalhar em troca de um salário ou operar uma tecnologia específica do indivíduo. Nós denominamos a segunda escolha de ocupação de atuação como um “empresário”, onde ele opera uma "firma”.

No modelo temos dois "regimes financeiros”, um com crédito e outro onde temos somente poupança. Os agentes no regime de poupança podem poupar mas não podem tomar empréstimos. A participação no regime de poupança é livre mas os agentes devem pagar um custo de participação para obter um empréstimo. O nível deste custo de participação é um dos determinantes das restrições financeiras. Ele leva em consideração custos de transação fixos, tarifas anuais elevadas, requerimentos de documentação e outras barreiras.

No regime de crédito os indivíduos podem obter empréstimos, contudo o montante emprestado é restrito por duas fricções financeiras adicionais: "limited commitment” e informação assimétrica. Estas friç̧ões distorcem a alocação de capital e de talento empresarial na economia, reduzindo a produtividade total dos fatores (TFP). A primeira fricção é modelada como uma restrição de endividamento, que surge do "enforcement" imperfeito dos contratos. Assim, os empresários devem fornecer colaterais para poder obter empréstimos. O valor dos colaterais é outro determinante das restrições financeiras, afetando o montante de crédito disponível. A segunda fricção financeira é decorrente da informação assimétrica entre bancos e tomadores de empréstimos. Neste contexto, as taxas de juros cobradas sobre os empréstimos devem cobrir o custo de monitoramento de empresários altamente alavancados. O custo de intermediação mais elevado é outra fonte de ineficiência e restrição financeira. 
O modelo possui um mecanismo onde as reduções nas fricções financeiras para as firmas elevam a TFP e o PIB. As restrições financeiras para as firmas impedem que elas (ou a maioria delas) escolham o nível de capital que maximiza o lucro irrestrito. Dado que o capital contratado depende dos ativos da firma, teremos nesta economia firmas muito produtivas com ativos baixos que contratam pouco capital e firmas pouco produtivas com ativos elevados que contratam muito capital. Isto gera uma alocação ineficiente do capital e reduz a TFP. Quando se reduz as friç̧ões financeiras, parte do capital flui das firmas menos produtivas para as mais produtivas o que eleva a TFP e o PIB.

As restrições financeiras para as firmas também impedem que indivíduos com alta habilidade e ativos baixos se tornem empresários. Isto gera uma alocação ineficiente do talento empresarial e reduz a TFP. O relaxamento das restrições financeiras permite que indivíduos de alta habilidade e ativos baixos se tornem empresários o que eleva adicionalmente a TFP e o produto.

O modelo foi calibrado para reproduzir momentos da economia brasileira em 2009. Uma parte dos parâmetros foi fixada levando em conta dados da economia brasileira e a literatura no Brasil. O restante dos parâmetros foi calibrado conjuntamente, de forma a reproduzir, no modelo, momentos específicos da economia brasileira em 2009. Os momentos reproduzidos no modelo foram a taxa de poupança da economia, os colaterais como percentual dos empréstimos, o percentual de firmas com crédito, a taxa de inadimplência, o “spread” da taxa de juros, os “overhead costs” como proporção dos ativos, o "share" do emprego das 5\% maiores firmas, o "share" do emprego das $10 \%$ maiores firmas, o "share” do emprego das $20 \%$ maiores firmas e o "share" do emprego das 40\% maiores firmas. O modelo reproduz bem os dados para 2009 no Brasil.

Neste texto realizamos três exercícios. No primeiro avaliamos os efeitos de reduções no custo de participação no mercado de crédito sobre a economia. No segundo analisamos os efeitos do relaxamento nas restrições de endividamento e no terceiro avaliamos os impactos de reduções no custo de monitoramento.

No primeiro exercício, a redução do custo de participação no mercado de crédito (que eleva o acesso financeiro para o nível dos países desenvolvidos) gera um aumento no PIB per capita de 3,6\%. No segundo exercício, a redução do custo de monitoramento (que eleva a eficiência do sistema para o nível dos países 
desenvolvidos) gera uma elevação no PIB per capita de 1,7\%. Por último, no terceiro exercício avaliamos um relaxamento nas restrições de endividamento que seria obtido se os colaterais como proporção dos empréstimos no Brasil fossem iguais à média dos países desenvolvidos. Os resultados mostram que a redução dos colaterais no Brasil elevaria o PIB per capita em 12\%.

Neste contexto, a restrição financeira com maior impacto sobre o PIB per capita, no caso brasileiro, é o limite de endividamento. Neste sentido, políticas voltadas para a redução das restrições de endividamento terão um impacto maior sobre o PIB do que políticas que visem reduzir o spread ou elevar a participação no mercado de crédito. Isto ocorre devido ao fato de que os empresários no Brasil são fortemente restritos por requerimentos de colaterais elevados. Assim uma redução no custo de intermediação somente beneficia um pequeno número de empresários que possuem colaterais suficientes para obter empréstimos.

Por fim, fazemos uma decomposição do crescimento do PIB per capita gerado pela redução das fricções financeiras. Os resultados mostram que reduzir o custo de participação no mercado de crédito ou reduzir o custo de intermediação eleva o PIB per capita principalmente pelo efeito na margem extensiva, onde mais empresários obtém crédito dos bancos. Por outro lado, relaxar a restrição de endividamento eleva o PIB per capita principalmente por meio da margem intensiva, por permitir que os empresários, que já estão no regime de crédito, elevem a produção.

O restante do texto é organizado da seguinte forma: a seção 2 fornece uma breve revisão da literatura relacionada ao trabalho, a seção 3 descreve o modelo utilizado, a seção 4 apresenta a calibração do modelo, a seção 5 descreve os resultados dos exercícios realizados e por fim, na seção 6 apresentamos as conclusões.

\section{2}

\section{Revisão da literatura}

Uma literatura crescente tem encontrado impactos consideráveis da melhoria da intermediação financeira sobre a produtividade agregada e o PIB per capita. Nosso trabalho está inserido nessa literatura que utiliza versões do modelo 
de crescimento neoclássico com agentes heterogêneos e fricções financeiras para avaliar o impacto do crédito sobre a TFP e o PIB per capita (Dabla_Norris e outros,2015; Buera e Shin,2013; Curtis,2016; Antunes, Cavalcanti e Villamil, 2008, 2014; Buera, Kaboski e Shin, 2011; Moll, 2014). Buera e Shin (2013) utilizam um modelo com escolha ocupacional para avaliar os impactos de longo prazo das restrições de crédito e a eliminação de distorções na economia na forma de impostos sobre o lucro. Eles avaliam reformas econômicas que levaram ao “milagre do crescimento” no leste asiático. Moll (2014) mostra que os impactos das fricções financeiras sobre o PIB e a TFP dependem da persistência dos choques idiossincráticos. Buera, Kaboski e Shin (2011) avaliam a relação entre TFP (agregada e setorial) e desenvolvimento financeiro entre países. Em seu modelo setores com grandes escalas de produção (como a manufatura) sofrem mais os efeitos das restrições de crédito uma vez que possuem maiores necessidades financeiras. Mostram que as restrições de crédito explicam uma parte substancial das diferenças observadas entre países no produto por trabalhador, TFP agregada e TFP setorial. Dabla_Norris e outros (2015) utilizam um modelo com escolha ocupacional e três fricções financeiras: um custo de participação no mercado de crédito, um custo de monitoramento e um limite de endividamento gerado por "limited commitment". Eles avaliam os impactos de reduções nas fricções financeiras sobre o PIB, TFP e distribuição da renda para um grupo de países em desenvolvimento e um grupo de países muito pobres. Os resultados demonstram que os efeitos das friç̧ões financeiras sobre cada economia dependem de características específicas de cada país.

Nosso trabalho está relacionado aos estudos que utilizam várias fricções financeiras em uma mesma estrutura teórica (Dabla_Norris e outros, 2015; Moll, Townsend e Zhorin, 2014 e Martin e Taddei, 2013). Moll, Townsend e Zhorin (2014) usam um modelo de equilíbrio geral com diferentes tipos de fricções financeira e avaliam as interações de equilíbrio entre as várias fricções. Martin e Taddei (2013) avaliam os impactos macroeconômicos da seleção adversa e comparam estes resultados com os obtidos com "limited commitment".

Nosso trabalho também está relacionado a uma literatura sobre “misallocation” (Hsieh e Klenow, 2009; Midrigan e Xu, 2014), dado que na modelagem que utilizamos, o aumento da eficiência na alocação dos recursos é importante para explicar os efeitos do crédito sobre a TFP. 
No Brasil temos poucos trabalhos que utilizam versões do modelo de crescimento neoclássico com agentes heterogêneos, escolha ocupacional e friç̧ões financeiras (Antunes, Cavalcanti e Villamil, 2008, 2014). Antunes e outros (2008) mostram que as fricções financeiras explicam grande parte da diferença na renda per capita entre Brasil e EUA. Antunes e outros (2014) avaliam os impactos de políticas de subsídios creditícios sobre a economia brasileira. Nestes trabalhos os autores utilizam uma estrutura com duas fricções financeiras: um limite de endividamento endógeno devido ao "limited commitment” e um “spread” dado exogenamente.

Em nosso trabalho utilizamos o modelo desenvolvido em Dabla_Norris e outros (2015). A nossa contribuição para a literatura no Brasil é utilizar uma modelagem com um mecanismo que permite avaliar, em uma mesma estrutura, os impactos de reduções em várias fricções financeiras sobre a TFP e o PIB per capita.

Neste sentido, a estrutura teórica que utilizamos em nosso trabalho é mais geral que a utilizada em trabalhos anteriores para o Brasil (como em Antunes, Cavalcanti e Villamil, 2008, 2014). Isto ocorre dado que o modelo que utilizamos (Dabla_Norris e outros, 2015) possui três fricções financeiras: um custo de participação no mercado de crédito, um "spread" devido a um custo de monitoramento e um limite de endividamento devido ao "limited commitment". Além disso, o "spread” é determinado endogenamente no modelo. Por outro lado, Antunes, Cavalcanti e Villamil (2008, 2014) utilizam uma modelagem com somente duas fricções financeiras: um limite de endividamento endógeno e um “spread" dado exogenamente.

\section{3}

\section{Modelo}

A estrutura teórica desenvolvida em Dabla_Norris e outros (2015) consiste de uma versão do modelo de crescimento neoclássico com famílias heterogêneas e firmas heterogêneas. O modelo inclui escolha ocupacional (como em Lucas, 1978), neste caso, o indivíduo decide ser trabalhador ou empresário de acordo com os incentivos. A economia possui três restrições financeiras: um custo de 
participação no mercado de crédito, um "spread" devido a um custo de monitoramento e um limite de endividamento devido ao "limited commitment". O modelo não possui incerteza agregada e o tempo é discreto.

\section{Heterogeneidade e demografia}

A população da economia é formada por um contínuo de agentes de medida um. Os agentes são heterogêneos com relação à riqueza inicial $b$ e o talento empresarial z. Os indivíduos vivem dois períodos. No primeiro período, eles decidem se participam do mercado de crédito, escolhem a ocupação e decidem as demandas de capital e trabalho, tomando como dadas as decisões ótimas de consumo e herança feitas no período seguinte. No período seguinte, os agentes decidem o consumo e a herança para maximizar a utilidade levando em conta a renda realizada. Cada indivíduo possui um herdeiro com riqueza igual à herança recebida e talento retirado de um processo estocástico.

\section{Agentes}

Os agentes geram utilidade somente no segundo período por meio do consumo e da herança para seu herdeiro. A função utilidade é Cobb-Douglas, dada por:

$$
u\left(c, b^{\prime}\right)=c^{1-\omega} b^{\prime \omega}
$$

Onde $c$ é o consumo e $b$ ' é a herança. No segundo período, os agentes maximizam a equação acima escolhendo $c$ e $b^{\prime}$ sujeito à restrição orçamentária $c+b^{\prime}=W$, onde $W$ é a riqueza no segundo período. Ela depende da riqueza inicial e da renda realizada no primeiro período.

A forma Cobb-Douglas da função utilidade implica em uma taxa de herança ótima de $\omega$. Neste caso, a função utilidade é uma função linear da riqueza realizada no segundo período $W$. Neste contexto, os agentes são neutros ao risco. Dessa forma, maximizar a utilidade esperada, é equivalente a maximizar a riqueza esperada no segundo período. Então no primeiro período, os agentes tomam decisões para maximizar a renda esperada.

No primeiro período, o agente faz uma escolha ocupacional entre ser trabalhador ou empresário. Cada trabalhador oferta uma unidade de trabalho. O talento é retirado de uma distribuição de Pareto $\mu(z)$ com um parâmetro de cauda 
$\theta$. O herdeiro mantém o talento dos seus pais com probabilidade $\gamma$, caso contrário, um novo talento é retirado de $\mu(z)$.

Os empresários têm acesso a uma tecnologia de produção onde a produtividade depende do talento do agente. A função de produção é dada por:

$$
f(z, k, l)=z\left(k^{\alpha} l^{1-\alpha}\right)^{1-v}
$$

Onde 1-v é o parâmetro do "span-of-control" de Lucas, que representa o "share" do produto dos fatores variáveis. Deste montante, uma fração $\alpha$ vai para o capital e uma fração 1- $\alpha$ vai para o trabalho. A função de produção possui retornos decrescentes de escala nos fatores variáveis, com $v>0$. A taxa de depreciação do capital é dada por $\delta$.

A produção falha com probabilidade $p$, e neste caso o produto é zero e os agentes são capazes de recuperar somente uma fração $\eta<1$ do capital instalado líquido de depreciação, no segundo período. Os trabalhadores são pagos somente no caso de sucesso da produção. Então cada trabalhador recebe um salário $w$ com probabilidade 1-p.

Todos os indivíduos podem fazer depósitos no intermediário financeiro para transferir riqueza entre períodos visando consumir e deixar herança. O agente necessita pagar um custo de participação no mercado de crédito $\psi$ para obter um contrato de empréstimo do intermediário financeiro. No modelo, por definição, se o agente paga o custo $\psi$ e pode tomar emprestado então ele vive no "regime de crédito". Se o agente não paga $\psi$ e pode somente poupar então ele vive no "regime de poupança”. Este custo pode ser considerado como uma tarifa contratual ou um custo de barganha com o intermediário financeiro. Os trabalhadores não tomam empréstimos. Os empresários tomam emprestado para contratar capital.

Dado o salário de equilíbrio $w$ e a taxa de depósito de equilíbrio $r^{d}$, os agentes do tipo $(b, z)$ decidem se participam do mercado de crédito e escolhem a ocupação para maximizar a renda esperada. O problema do indivíduo é resolvido em dois passos. Primeiro, ele escolhe a ocupação condicional ao regime em que vive. Depois ele escolhe o regime, comparando a renda esperada que pode ser obtida em cada um deles. O problema de escolha ocupacional nos regimes de poupança e de crédito é apresentado a seguir. 


\section{Regime de poupança}

Os indivíduos que vivem no regime de poupança não podem tomar empréstimos do intermediário financeiro. Eles têm que financiar a produção usando recursos próprios. No primeiro período, o objetivo do agente é maximizar a renda esperada. Dada a riqueza inicial, maximizar a renda esperada é equivalente a maximizar a riqueza esperada do segundo período $W$.

Definindo $\pi(b, z)$ como a função riqueza esperada de final de período para o empresário do tipo $(b, z)$ e denotando as variáveis no regime de poupança com o sobrescrito $s$ temos:

$$
\begin{aligned}
& W^{s}=\left(1+r^{d}\right) b+(1-p) w \text { para trabalhadores, } \\
& \pi^{s}(b, z) \quad \text { para empresários, }
\end{aligned}
$$

Dado que os agentes são neutros ao risco, eles escolhem atuar como trabalhadores se:

$$
\left(1+r^{d}\right) b+(1-p) w>\pi^{s}(b, z)
$$

Caso contrário, escolhem ser empresários.

Então a riqueza de final de período pode ser escrita como:

$$
W^{s}=\max \left\{\left(1+r^{d}\right) b+(1-p) w, \pi^{s}(b, z)\right\}
$$

A função riqueza para os empresários é obtida do seguinte problema de maximização:

$$
\begin{aligned}
& \pi^{s}(b, z)=\max _{k, l}(1-p)\left(z\left(k^{\alpha} l^{1-\alpha}\right)^{1-v}-w l+(1-\delta) k\right)+p \eta(1-\delta) k+\left(1+r^{d}\right)(b-k) \\
& \text { s.a. } k \leq b
\end{aligned}
$$

A produção tem sucesso com probabilidade 1-p e o empresário obtém a receita $z\left(k^{\alpha} l^{1-\alpha}\right)^{1-v}-w l$ mais o capital de giro não depreciado $(1-\delta) k$. A produção falha com probabilidade $p$ e o empresário recupera somente uma fração $\eta$ do capital de giro não depreciado. O termo $\left(1+r^{d}\right)(b-k)$ corresponde à parte da riqueza não utilizada na produção incluindo o rendimento de juros. A restrição reflete o fato de que os empresários precisam utilizar a própria riqueza para financiar o capital. 
Dabla_Norris e outros (2015) mostram que, no regime de poupança, a quantidade ótima de capital investida pelo empresário do tipo $(b, z)$ e a demanda de trabalho ótima são dados por ${ }^{16}$ :

$$
\begin{gathered}
k^{*}(b, z)=\min \left(b, \hat{k}^{s}(z)\right) \\
l^{*}(b, z)=\left[\frac{z(1-\alpha)(1-v)}{w}\right]^{\frac{1}{\alpha(1-v)+v}} k^{*}(b, z)^{\frac{\alpha(1-v)}{\alpha(1-v)+v}}
\end{gathered}
$$

Onde: $\quad \tilde{k}^{s}(z)=\left[\frac{\alpha w(1-p)}{(1-\alpha)\left(r^{d}+(1-p) \delta-p \eta(1-\delta)+p\right)}\right]^{\frac{\alpha(1-v)+v}{v}}\left(\frac{(1-v)(1-\alpha) z}{w}\right)^{\frac{1}{v}}$ é o nível de capital irrestrito no regime de poupança.

Temos que $\tilde{k^{s}}(z)$ é o montante desejado de capital que os empresários no regime de poupança gostariam de investir quando não são restritos pela riqueza.

Para empresários com riqueza menor que $\tilde{k}^{s}(z)$, a demanda de capital é restrita pela riqueza: $k^{*}(b, z)=b$.

\section{Regime de crédito}

Os agentes entram no regime de crédito e obtém acesso a financiamento quando pagam o custo de participação $\psi$. Os trabalhadores não podem tomar empréstimos, então somente temos empresários no regime de crédito.

O intermediário financeiro é perfeitamente competitivo (aqui denominamos o mesmo de banco). Para poder obter empréstimos, o agente precisa assinar um contrato com o banco. Um contrato financeiro é definido pelo trio ordenado $(\Phi, \Delta, \Omega)$, onde $\Phi$ é o montante tomado emprestado, $\Delta$ é o valor dos colaterais, ou seja, o valor dos ativos dados ao banco como garantia do empréstimo, e $\Omega$ é o valor de face do contrato (montante que deve ser pago pelo tomador se não ocorre inadimplência). Os colaterais rendem juros, ou seja, os agentes recebem a taxa de depósito $r^{d}$ sobre o valor do colateral.

A taxa de juros do empréstimo implicada pelo contrato financeiro é dada por:

$$
r^{l}=\frac{\Omega}{\Phi}-1
$$

A taxa de alavancagem (montante do empréstimo relativo ao tamanho do colateral) é dada por:

\footnotetext{
${ }^{16}$ Vide proposição A.1 no Anexo A.
} 


$$
\tilde{\lambda}=\frac{\Phi}{\Delta}
$$

Se a produção falha, o empresário pode não ser capaz de repagar o valor de face do empréstimo $\Omega$. Neste caso, o empresário fica inadimplente e o banco se apropria do colateral incluindo juros $\left(1+\mathrm{r}^{\mathrm{d}}\right) \Delta$ e do valor recuperado do capital de giro não depreciado $\eta(1-\delta) k$. Desde que o empresário altamente alavancado fica inadimplente no caso de uma falha na produção, a taxa do empréstimo cobrada dele é mais alta no caso de sucesso na produção. Isto ocorre para compensar as perdas do banco no caso de falha na produção.

Devido ao "limited commitment”, o empresário precisa fornecer colaterais ao banco para poder obter empréstimos. O banco está disposto a emprestar no máximo $\lambda \Delta$ se o empresário fornece o montante $\Delta$ de colaterais ${ }^{17}$. Então a restrição de endividamento é dada por:

$$
\Phi \leq \lambda \Delta
$$

O parâmetro $\lambda \geq 1$ captura o grau de fricção financeira resultante do "limited commitment”.

Existe informação assimétrica entre os empresários e o banco, dado que somente o empresário sabe se teve sucesso ou não na produção. O empresário tem a opção de ficar inadimplente quando a produção falha. Neste caso, ele pode pagar menos se uma falsa falha na produção é reportada e a mentira não é descoberta pelo banco. O intermediário financeiro possui uma tecnologia de monitoramento por meio da qual ele obtém informação sobre o sucesso da produção a um custo proporcional à escala de produção (ou seja, um custo $\chi$ por unidade de capital). Se o empresário é pego trapaceando, o banco pode forçar legalmente o repagamento pleno do valor de face do empréstimo. Dado que o lucro do banco é zero em equilíbrio, o custo de monitoramento é atribuído ao empresário quando o contrato financeiro é desenhado.

\footnotetext{
${ }^{17}$ No modelo, a restrição de endividamento é exógena. Contudo, sua justificativa é a hipótese de "limited commitment”. Esta restrição captura a predição comum dos modelos de contratos com “enforcement” limitado de que o montante de crédito é limitado pela riqueza do indivíduo. A restrição do fornecimento de colaterais pode ser derivada do seguinte problema de "limited commitment” (segundo Dabla_Norris e outros,2015 e Buera e Shin,2013): Suponha que o empresário pode tomar emprestado $\Phi$ se fornece o montante $\Delta$ de colaterais para o banco. Suponha também que o "enforcement” do contrato é imperfeito e neste caso o empresário pode "roubar" imediatamente uma fração $1 / \lambda$ do capital alugado. A única punição é que ele perde o seu colateral $\Delta$. Em equilíbrio, o empresário não "rouba" somente se $\Phi / \lambda<\Delta$. Neste caso, o banco está disposto a emprestar no máximo $\lambda \Delta$ para o empresário se ele fornece o montante $\Delta$ de colateral.
} 
No regime de crédito a riqueza de final de período é denotada por:

$$
W^{c}=\pi^{c}(b, z)
$$

Onde o sobrescrito $c$ refere-se ao regime de crédito. Os agentes escolhem pagar o custo de participação no mercado de crédito quando $W^{c}>W^{s}$.

O empresário busca maximizar a riqueza esperada do segundo período dada por:

$$
\begin{aligned}
& \pi^{C}(b, z)=\max _{k, l}(1-p)\left(z\left(k^{\alpha} l^{1-\alpha}\right)^{1-v}-w l+(1-\delta) k-\Omega+\left(1+r^{d}\right)(b-\psi)\right) \\
& +p \max \left(0, \eta(1-\delta) k+\left(1+r^{d}\right)(b-\psi)-\Omega\right) \\
& \text { s.a. } \quad k \leq \lambda(b-\psi)
\end{aligned}
$$

Na equação acima, o primeiro termo refere-se à riqueza de final de período quando a produção tem sucesso. O segundo termo é referente ao caso de falha na produção. Os empresários ficam com riqueza positiva somente se $\eta(1$ $\delta) \mathrm{k}+\left(1+\mathrm{r}^{\mathrm{d}}\right)(\mathrm{b}-\psi)>\Omega$, ou seja, quando o capital de giro não depreciado recuperado mais o valor do colateral incluindo juros é suficiente para pagar o empréstimo. Caso contrário, o empresário finaliza com riqueza de final de período igual a zero.

O banco não pode observar o tipo do empresário $(b, z)$ e neste caso, tem que fornecer um menu de contratos. Cada empresário escolhe o seu contrato ótimo do menu. A relação de contratos é desenhada de forma a ser compatível em incentivos. Neste caso, o empresário do tipo $(b, z)$ não tem incentivos em imitar o do tipo ( $\left.b^{\prime}, z^{\prime}\right)$ e escolher o contrato ótimo do outro empresário. Cada contrato rende lucro esperado zero para o banco. A receita esperada do banco em um contrato de empréstimo para um agente do tipo $(b, z)$ é dada por:

$$
(1-p) \Omega+p \min \left(\Omega, \eta(1-\delta) k+\left(1+r^{d}\right)(b-\psi)\right)
$$

O primeiro termo diz respeito à receita quando a produção tem sucesso, que ocorre com probabilidade 1-p. Neste caso, o banco recebe o valor de face pleno do empréstimo $\Omega$. O segundo termo é referente à receita quando a produção falha. Neste contexto, antes de pagar a dívida o empresário obtém o valor do capital de giro recuperado $\eta(1-\delta) k$ mais o valor do colateral incluindo juros $\left(1+r^{d}\right)(b-\psi)$. O banco recebe o valor de face pleno do empréstimo $\Omega$ se o que o empresário recuperou na falha da produção é suficiente para pagar o empréstimo. Caso contrário, o banco se apropria de tudo o que o empresário conseguiu recuperar na falha da produção e o empresário finaliza com nada. Então no caso de falha na produção, o banco recebe o menor valor entre $\Omega$ e $\eta(1-\delta) k+\left(1+r^{d}\right)(b-\psi)$. 
No caso da despesa, o custo esperado do contrato de empréstimo para o banco é o valor do empréstimo incluindo os juros $\left(1+r^{d}\right) k$ mais o custo esperado de monitoramento. Este monitoramento ocorre somente se o empresário não pode pagar o empréstimo, ou seja, quando a produção falha e o valor recuperado $\eta(1-$ $\delta) k+\left(1+r^{d}\right)(b-\psi)$ é menor que o valor de face do empréstimo $\Omega$. Neste caso, temos um custo de monitoramento $\chi k$. O custo esperado de monitoramento é igual ao custo de monitoramento multiplicado pela taxa de monitoramento. A taxa de monitoramento é igual à taxa de falha na produção $p$ quando os empresários são altamente alavancados $\eta(1-\delta) \mathrm{k}+\left(1+\mathrm{r}^{\mathrm{d}}\right)(\mathrm{b}-\psi)<\Omega$. Caso contrário, a taxa é igual a zero. Então o custo esperado de monitoramento é dado por:

$$
p \chi k \cdot 1_{\left\{\eta(1-\delta) k+\left(1+r^{d}\right)(b-\psi)<\Omega\right\}}
$$

Onde $1_{\left\{\eta(1-\delta) k+\left(1+r^{d}\right)(b-\psi)<\Omega\right\}}$ é uma função indicadora que é igual a 1 se a condição entre chaves é verdadeira. Caso contrário, é igual a zero. O custo do contrato de empréstimo é dado por:

$$
\left(1+r^{d}\right) k+p \chi k \cdot 1_{\left\{\eta(1-\delta) k+\left(1+r^{d}\right)(b-\psi)<\Omega\right\}}
$$

A condição de lucro zero do banco é obtida quando a receita esperada do contrato é igual ao custo esperado:

$$
\begin{aligned}
& (1-p) \Omega+p \min \left(\Omega, \eta(1-\delta) k+\left(1+r^{d}\right)(b-\psi)\right)= \\
& \left(1+r^{d}\right) k+p \chi k \cdot 1_{\left\{\eta(1-\delta) k+\left(1+r^{d}\right)(b-\psi)<\Omega\right\}}
\end{aligned}
$$

Para resolver o contrato de empréstimo ótimo $(\Phi, \Delta, \Omega)$ para o empresário do tipo $(b, z)$ devemos notar que os colaterais rendem juros e neste caso, os empresários estão dispostos a colocar toda sua riqueza líquida do custo de participação $b$ - $\psi$ como colaterais em vez de depositar uma fração dela em uma conta de poupança. Assim, o termo $\Delta=\mathrm{b}-\psi$ pertence ao conjunto dos contratos de empréstimos ótimos. Além disso, os empresários pedem empréstimos para aumentar a produção e obter lucros maiores. Neste caso, não existe razão para tomar emprestado recursos do banco e não usá-los na produção, desde que isto somente elevaria a taxa de alavancagem o que poderia elevar o custo do capital. Deste modo, o montante de empréstimo $\Phi$ é igual ao montante de capital $k(b, z)$, quando o contrato de empréstimo é ótimo. 
O contrato ótimo $(\Phi, \Delta, \Omega)$ é obtido como solução do problema de maximização da riqueza esperada do empresário do tipo $(b, z)$ sujeito à restrição de lucro zero do banco:

$$
\begin{aligned}
& \max _{\Phi, \Delta, \Omega} \pi^{C}(b, z) \\
& \text { S.a. } \\
& (1-p) \Omega+p \min \left(\Omega, \eta(1-\delta) k+\left(1+r^{d}\right)(b-\psi)\right)= \\
& \left(1+r^{d}\right) k+p \chi k \cdot 1_{\left\{\eta(1-\delta) k+\left(1+r^{d}\right)(b-\psi)<\Omega\right\}}
\end{aligned}
$$

Onde:

$$
\begin{aligned}
& \pi^{C}(b, z)=\max _{k, l}(1-p)\left(z\left(k^{\alpha} l^{1-\alpha}\right)^{1-v}-w l+(1-\delta) k-\Omega+\left(1+r^{d}\right)(b-\psi)\right) \\
& +p \max \left(0, \eta(1-\delta) k+\left(1+r^{d}\right)(b-\psi)-\Omega\right) \\
& \text { s.a. } \quad k \leq \lambda(b-\psi)
\end{aligned}
$$

Como $\Delta=\mathrm{b}-\psi$ e $\Phi=\mathrm{k}(\mathrm{b}, \mathrm{z})$, basta obter $\mathrm{k}(\mathrm{b}, \mathrm{z})$ e $\Omega$ para resolver o contrato ótimo. O problema acima é resolvido para $\mathrm{k}(\mathrm{b}, \mathrm{z})$ e $\Omega(\mathrm{b}, \mathrm{z})$ simultaneamente. Townsend (1979) e Gale e Hellwig (1985) mostram que a solução do problema acima, ou seja, o contrato ótimo, é um contrato de dívida “padrão” com estratégia de verificação ótima do banco decidida ex-ante e determinada pelo contrato $(\Phi, \Delta, \Omega)$, parâmetros $\eta$ e $\delta$ e a taxa de depósito $r^{d}$, onde:

a) Nenhuma verificação ocorre em um empréstimo com baixa alavancagem:

$$
\eta(1-\delta) \Phi+\left(1+r^{d}\right) \Delta \geq \Omega
$$

b) Verificação ocorre se a produção falha em um empréstimo com alta alavancagem:

$$
\eta(1-\delta) \Phi+\left(1+r^{d}\right) \Delta<\Omega
$$

A verificação ou monitoramento do banco ocorre se o empresário não pode pagar o valor de face do empréstimo. Isto ocorre quando o empresário é altamente alavancado e também experimenta uma falha na produção. Quando a produção tem sucesso, o empresário pode pagar o valor de face do empréstimo. Neste caso, o banco não tem nenhum incentivo para monitorar. Contudo, se uma falha na produção é reportada, o banco monitora somente se o contrato de empréstimo é altamente alavancado. Isto ocorre dado que no caso de baixa alavancagem, o empresário possui recursos suficientes para pagar o valor de face do empréstimo independentemente do resultado da produção. Assim, o empresário não tem nenhum incentivo para mentir, pois tem que pagar o valor de 
face do empréstimo em qualquer resultado da produção. Neste caso, o banco também não tem incentivos para monitorar.

Por outro lado, se o contrato de empréstimo é altamente alavancado e a produção falha, o montante que o empresário pode pagar não é suficiente para cobrir o valor de face do empréstimo e ocorre a inadimplência. Neste contexto, o empresário tem um incentivo para mentir quando a produção tem sucesso dado que ele sabe que com alta alavancagem, pagaria menos se uma falha de produção for reportada. Assim, para motivar "truth-telling", o banco verifica todo contrato de empréstimo altamente alavancado se uma falha na produção é reportada.

Neste texto nos restringimos ao caso onde a inadimplência pode ocorrer, com taxa de juros endógena de equilíbrio satisfazendo ${ }^{18}$ :

$$
r^{d}>\frac{\eta(1-\delta) \lambda}{\lambda-1}-1
$$

No regime de crédito a inadimplência ocorre para empresários altamente alavancados. Para um empresário que opera sua firma com uma taxa de alavancagem $\tilde{\lambda} \operatorname{temos}^{19}$ :

a) Se $\tilde{\lambda} \leq \bar{\lambda}$ (região de baixa alavancagem) a inadimplência nunca ocorre e a taxa de empréstimo é dada por $r^{l}=r^{d}$.

b) $\tilde{\lambda}>\bar{\lambda}$ (região de alta alavancagem) a inadimplência ocorre quando a produção falha e a taxa de empréstimo é crescente em $\tilde{\lambda}$ e dada por:

$$
r^{l}=\frac{1+r^{d}+p \chi-p \eta(1-\delta)-p\left(1+r^{d}\right) \tilde{\lambda}^{-1}}{1-p}-1
$$

Onde $\bar{\lambda}=\frac{1+\mathrm{r}^{\mathrm{d}}}{1+\mathrm{r}^{\mathrm{d}}-\eta(1-\delta)}$ é o limite de inadimplência.

O resultado acima estabelece que a inadimplência ocorre somente para empresários altamente alavancados quando a produção falha. Para empresários sem risco de inadimplência $(\tilde{\lambda} \leq \bar{\lambda})$ o banco sempre recebe o valor de face do empréstimo e a taxa de empréstimo implicada $r^{l}$ é igual à taxa de depósito $r^{d}$. Para

\footnotetext{
${ }^{18}$ A condição (22) é necessária para que nesta economia existam empresários que possam ficar inadimplentes. Se ela não é satisfeita, mesmo no caso de falha de produção nenhum empresário fica inadimplente (vide prova da proposição 2 no Anexo A).

${ }^{19}$ Vide proposição 2 do Anexo A para derivação desses resultados.
} 
empresários com risco de inadimplência $(\tilde{\lambda}>\bar{\lambda})$ a taxa de empréstimo implicada é crescente na taxa de alavancagem para compensar perdas no caso de inadimplência. Para empresários altamente alavancados a taxa de empréstimo inclui um prêmio de risco que depende da taxa de alavancagem e do custo de intermediação devido ao monitoramento do banco.

Note que a taxa de empréstimo não é igual ao custo do capital encarado pelo empresário. A taxa de empréstimo é a taxa de juros que o empresário tem que pagar quando a produção tem sucesso. Se a produção falha o empresário tem a opção de ficar inadimplente e pagar menos. Neste caso, o custo do capital é a média ponderada da taxa do empréstimo e da taxa de pagamento quando ocorre a inadimplência ${ }^{20}$.

A solução do contrato ótimo, descrito acima, permite obter a demanda ótima de capital do empresário do tipo (b,z). Dabla_Norris e outros (2015) mostram que a demanda de capital ótima é dada pelo seguinte resultado descrito abaixo $^{21}$ :

No regime de crédito, para o empresário do tipo $(b, z)$, a taxa de alavancagem ótima é definida por $\lambda^{*}(b, z)$ e a demanda de capital ótima por $k^{*}(b, z)$. Existe um nível de riqueza crítico $\bar{b}(z)$, tal que:

$$
\begin{aligned}
& \text { a) Se } \psi \leq \mathrm{b}<\overline{\mathrm{b}}(z) \text { então: } \bar{\lambda}<\lambda^{*}(b, z) \leq \lambda \quad \text { e } \\
& k^{*}(b, z)=\min \left(\lambda(b-\psi), \tilde{k^{h}}(z)\right)
\end{aligned}
$$

Onde:

$\tilde{k^{h}}(z)=\left[\frac{(1-p) \alpha w}{\left(r^{d}+p \chi+(1-p) \delta-p \eta(1-\delta)+p\right)(1-\alpha)}\right]^{\frac{\alpha(1-v)+v}{v}}\left(\frac{(1-v)(1-\alpha) z}{w}\right)^{\frac{1}{v}}$ é 0 nível de capital ótimo irrestrito na região de alta alavancagem.

$$
\begin{aligned}
& \text { b) Se } \mathrm{b} \geq \overline{\mathrm{b}}(z) \text { então }: \lambda^{*}(b, z) \leq \bar{\lambda} \text { e } \\
& k^{*}(b, z)=\min \left(\bar{\lambda}(b-\psi), \tilde{k}^{l}(z)\right)
\end{aligned}
$$

\footnotetext{
${ }^{20}$ Vide Dabla_Norris e outros (2015) para uma derivação da expressão para o custo do capital.

${ }^{21}$ Vide proposição 3 do Anexo A.
} 
Onde $\quad \tilde{k}^{l}(z)=\left[\frac{(1-p) \alpha w}{\left(r^{d}+(1-p) \delta-p \eta(1-\delta)+p\right)(1-\alpha)}\right]^{\frac{\alpha(1-v)+v}{v}}\left(\frac{(1-v)(1-\alpha) z}{w}\right)^{\frac{1}{v}}$ é $\quad$ o nível de capital ótimo irrestrito na região de baixa alavancagem.

Note que $k^{h}(z)<k^{l}(z)$ para todo $z$. Isto ocorre dado que na região de alta alavancagem o banco monitora quando a produção falha o que eleva o custo do capital. Para empresários com riqueza baixa, o retorno marginal do capital é alto.

A receita extra gerada por uma maior alavancagem acima de $\bar{\lambda}$ supera o aumento no custo do capital. Assim eles escolhem uma alavancagem mais elevada $(\tilde{\lambda}>\bar{\lambda})$. Contudo, para empresários relativamente ricos, o retorno marginal do capital é baixo. Neste caso, eles escolhem tomar menos emprestado e permanecer na região de baixa alavancagem para evitar pagar o custo de monitoramento.

No contrato ótimo, a solução para o valor de face $\Omega$ é dada por $^{22}$ :

$$
\text { a) Se } \tilde{\lambda} \leq \bar{\lambda} \text { então: } \Omega=\left(1+r^{d}\right) k^{*}(b, z)
$$

b) Se $\tilde{\lambda}>\bar{\lambda}$ então:

$$
\Omega=\frac{\left(1+r^{d}\right) k^{*}(b, z)+p \chi k^{*}(b, z)-p \eta(1-\delta) k^{*}(b, z)-p\left(1+r^{d}\right)(b-\psi)}{1-p}
$$

Todos os contratos oferecidos pelo banco são compatíveis em incentivos, embora o talento não seja observado. Neste caso, o empresário com baixo talento não tem nenhum incentivo a fingir ser um de talento alto e pedir um contrato diferente, ou vice-versa. Para verificar isso, podemos dividir ambos os lados da equação de lucro zero do banco por k:

$$
\begin{aligned}
& (1-p) \frac{\Omega}{k}+p \min \left(\frac{\Omega}{k}, \eta(1-\delta)+\left(1+r^{d}\right) \frac{(b-\psi)}{k}\right)= \\
& \left(1+r^{d}\right)+p \chi \cdot 1_{\left\{\eta(1-\delta)+\left(1+r^{d}\right) \frac{(b-\psi)}{k}<\frac{\Omega}{k}\right\}}
\end{aligned}
$$

A equação acima mostra que a taxa de empréstimo bruta $\Omega / \mathrm{k}$ depende somente do inverso da taxa de alavancagem $(b-\psi) / k$, e não depende diretamente do talento do empresário. O capital $k$ e o talento $z$ entram na equação somente por meio da taxa de alavancagem que é observada. Portanto, para todo empresário, dado o montante de capital que ele deseja investir e o montante de riqueza que ele

\footnotetext{
${ }^{22}$ Vide prova da proposição 2 no Anexo A.
} 
possui, não é possível receber uma taxa de juros mais baixa do banco trapaceando no talento.

\section{Equilíbrio competitivo}

Dada uma distribuição conjunta inicial de riqueza e talento da população $H_{0}(b, z)$ (e sua função densidade de probabilidade associada $h_{0}(b, z)$ ), um equilíbrio competitivo consiste de alocações $\left\{c_{t}(b, z), k_{t}(b, z), l_{t}(b, z)\right\}_{t=0}^{\infty}$, sequências de distribuições conjuntas de riqueza e talento $\left\{H_{t}(b, z)\right\}_{t=1}^{\infty}$ e preços $\left\{r^{d}(t), w(t)\right\}_{t=0}^{\infty}$, tais que:

1) Os agentes do tipo $(b, z)$ escolhem de forma ótima o regime, a ocupação, o consumo $c_{t}(b, z)$, a demanda por capital $k_{t}(b, z)$ e a demanda por trabalho $l_{t}(b, z)$ para maximizar a utilidade em todo $t \geq 0$.

2) O mercado de capital se equilibra para todo $t \geq 0$ :

$$
\iint_{(b, z) \in E(t)} k_{t}(b, z) h_{t}(b, z) d b d z=\iint_{(b, z)} b h_{t}(b, z) d b d z-\psi \iint_{(b, z) \in \operatorname{Fin}(t)} h_{t}(b, z) d b d z
$$

Onde $E(t)$ é o conjunto dos agentes que escolhem ser empresários em $t$. Fin(t) é o conjunto dos agentes que estão no regime de crédito.

3) O mercado de trabalho se equilibra para todo $t \geq 0$ :

$$
\iint_{(b, z) E E(t)} l_{t}(b, z) h_{t}(b, z) d b d z=\iint_{(b, z) E E(t)} h_{t}(b, z) d b d z
$$

4) A distribuição conjunta de riqueza e talento evolui de acordo com o mapeamento de equilíbrio:

$$
H_{t+1}(\bar{b}, \bar{z})=\gamma \int_{b}\left[\int_{z^{\prime} \leq \bar{z}} 1_{\left\{b^{\prime}\left(b, z^{\prime}\right) \leq \bar{b}\right\}} d z^{\prime}\right] h_{t}\left(b, z^{\prime}\right) d b+(1-\gamma) \mu(\bar{z}) \iint_{z} \int_{b} 1_{\left\{b^{\prime}(b, z) \leq \bar{b}\right\}} h_{t}(b, z) d z d b
$$

nde $b^{\prime}(b, z)$ é a herança ótima deixada pelo agente do tipo $(b, z)$ e $1_{\left\{b^{\prime}(b, z) \leq \bar{b}\right\}}$ é uma função indicadora que é igual a um se, para um dado $(b, z)$, a condição entre chaves é satisfeita, e é igual a zero caso contrário. A variável z’ representa o talento do agente no período seguinte. 


\section{4}

\section{Calibração}

Nós calibramos o modelo para reproduzir determinados momentos da economia brasileira em 2009. Para tanto, os dados sobre colaterais como percentual dos empréstimos e do percentual de firmas com acesso a crédito foram obtidos do "World Bank Enterprise Surveys". Os dados sobre taxa de inadimplência e spread da taxa de juros foram obtidos do BACEN. Os dados sobre "overhead costs" foram obtidos do "World Bank Global Financial Development Database”. A taxa de poupança da economia foi obtida das Contas Nacionais. Os momentos referentes à distribuição do emprego nas maiores firmas foram obtidos do Cadastro Central de Empresas do IBGE.

Com relação aos dados descritos acima, devemos ressaltar os colaterais como percentual dos empréstimos e o percentual de firmas com acesso a crédito. Eles foram obtidos do "World Bank Enterprise Surveys”. No caso do Brasil, esta pesquisa do Banco Mundial produziu dados a partir de uma amostra de 1802 empresas em 2009. Elas responderam a um questionário detalhado incluindo informações financeiras sobre colaterais e acesso a crédito.

Nós utilizamos valores padronizados da literatura para calibrar parte dos parâmetros. A taxa de depreciação anual $\delta$ foi fixada em 0,06 como em Dabla_Norris e outros (2015) e Buera e Shin (2013). No caso do Brasil, os trabalhos utilizam taxas de depreciação entre 0,03 e 0,10, e assim a taxa fixada está dentro do intervalo de taxas usadas ${ }^{23}$. O parâmetro que controla o "share" dos lucros foi calibrado em $v=0,21$ seguindo a literatura como em Buera e Shin (2013) e Dabla_Norris e outros (2015). A participação do capital na renda total foi calculada a partir dos dados das Contas Nacionais do IBGE. Adotamos a hipótese de que esta participação inclui o total do rendimento misto (dos autônomos). Supomos um processo estocástico com talento altamente persistente ${ }^{24}$. Neste

\footnotetext{
${ }^{23}$ Vide Cavalcanti (2008), Ellery e Bugarin (2003), Salami e Fochezatto (2009) e Morandi e Reis (2004), para exemplos dos valores utilizados para $\delta$.

${ }^{24}$ Com um processo altamente persistente um indivíduo habilidoso consegue obter rendimentos elevados por um período maior de tempo, antes que perca esta habilidade. Isto permite que ele poupe recursos suficientes para superar a restrição de crédito e se tornar empresário por meio do autofinanciamento. Em termos agregados, Moll (2014) mostra que choques, na habilidade empresarial, altamente persistentes geram perdas reduzidas na TFP no longo prazo em relação ao nível eficiente (que é aquele sem fricções financeiras). Isto ocorre uma vez que, se a habilidade é
} 
sentido, a probabilidade de que o agente herde o talento dos pais é fixada em $\gamma=$ 0,894 como em Buera e Shin (2013) e Dabla_Norris e outros (2015).

Os sete parâmetros restantes foram calibrados conjuntamente para reproduzir no modelo seis momentos e a distribuição do "share" do emprego da economia brasileira em 2009. Estes momentos são a taxa de poupança da economia, os colaterais requeridos como percentual do empréstimo, o percentual de firmas com crédito, a taxa de inadimplência das firmas, o "spread" da taxa de juros para as firmas, os custos “overhead” em relação aos ativos dos bancos e a distribuição do "share” do emprego nas maiores firmas. Esta distribuição é representada por quatro momentos calibrados da mesma: o percentual do emprego nas $5 \%$ maiores firmas, nas $10 \%$ maiores firmas, nas $20 \%$ maiores firmas e nas 40\% maiores firmas. Os parâmetros são calibrados conjuntamente, contudo cada parâmetro específico está mais diretamente relacionado a um momento específico.

Tabela 3.1: Parâmetros do modelo.

\begin{tabular}{|l|l|l|}
\hline \multicolumn{2}{|c|}{ Parâmetros fixados } \\
\hline Parâmetros & Valores & Comentários \\
\hline$Y$ & 0,89 & Controla a persistência de (z) \\
\hline$v$ & 0,21 & Controla o share dos lucros \\
\hline$\delta$ & 0,06 & Taxa de depreciação \\
\hline$\alpha(1-v)$ & 0,316 & Share da renda do capital \\
\hline & Parâmetros calibrados conjuntamente \\
\hline$\omega$ & 0,179 & \% herança deixada (taxa poupança) \\
\hline$\lambda$ & 2,12 & Controla colaterais (\% dos emprést) \\
\hline$\Psi$ & 0,053 & Controla \% de firmas com crédito \\
\hline$p$ & 0,11 & Taxa de inadimplência \\
\hline$X$ & 0,85 & Spread \\
\hline$\eta$ & 0,56 & Overhead costs/assets \\
\hline$\theta$ & 3,80 & Distrib share do emprego nas firmas \\
\hline
\end{tabular}

Cada geração é interpretada como um ano como em Giné e Townsend (2004), Jeong e Townsend (2008) e Dabla_Norris e outros (2015). A taxa de herança ótima foi calibrada em $\omega=0,179$. Ela foi utilizada para calibrar a taxa de

suficientemente persistente, o autofinanciamento é um substituto efetivo para o acesso ao crédito no longo prazo. 
poupança bruta da economia. O parâmetro $\lambda$, que captura o grau de fricção financeira gerado pelo "limited commitment" e controla a restrição de endividamento, foi calibrado para reproduzir no modelo o valor médio do colateral como um percentual do empréstimo ${ }^{25}$. O custo de participação no mercado de crédito $\psi$ foi utilizado para calibrar o percentual de firmas com crédito. A probabilidade de falha na produção $p$ foi calibrada para reproduzir a taxa de inadimplência. O parâmetro $\theta$, que controla a forma da distribuição do talento empresarial, foi ajustado para calibrar a distribuição do percentual de emprego nas firmas. Em termos mais específicos, foram calibrados quatro momentos desta distribuição. O parâmetro que controla o custo de monitoramento $\chi$ foi calibrado para reproduzir no modelo o spread da taxa de juros da economia. A fração recuperada do capital instalado $\eta$ foi ajustada para calibrar os "overhead costs” em relação aos ativos médios dos bancos ${ }^{26}$.

A tabela 3.2 mostra o ajuste do modelo em relação à economia brasileira em 2009.

Tabela 3.2: Ajuste do modelo.

\begin{tabular}{|l|c|c|}
\hline & $\begin{array}{c}\text { Economia brasileira } \\
\text { Em 2009 }\end{array}$ & Modelo base \\
\hline Poupança (\% do PIB) & 17,9 & 17,9 \\
\hline Colaterais (\% dos emprést) & 95,1 & 95,1 \\
\hline Firmas com crédito (\%) & 59,2 & 60,4 \\
\hline Taxa de inadimplência (\%) & 3,8 & 4,7 \\
\hline Spread da taxa de juros & 12,2 & 10,8 \\
\hline Overhead costs/ativos & 3,7 & 3,0 \\
\hline Share emprego 5\% maiores firmas & 67,0 & 59,0 \\
\hline Share emprego 10\% maiores firmas & 74,6 & 70,7 \\
\hline Share emprego 20\% maiores firmas & 83,2 & 81,4 \\
\hline Share emprego 40\% maiores firmas & 89,4 & 91,1 \\
\hline
\end{tabular}

Fontes: CONTAS NACIONAIS - IBGE, WORLD BANK GLOBAL FINANCIAL DEVELOPMENT DATABASE, WORLD BANK ENTERPRISE SURVEYS, CADASTRO CENTRAL DE EMPRESAS - IBGE e BACEN.

\footnotetext{
${ }^{25}$ Note que a definição da relação colateral/empréstimo no modelo é diferente da definição nos dados. No modelo, o empresário deposita sua riqueza $b$ no banco como colateral e toma emprestado $k^{*}$. Assim a relação colateral/empréstimo é $\lambda_{\text {model }}=k^{*} / b$. Nos dados, a relação é medida como $\lambda_{\text {data }}=\left(k^{*}-b\right) / b$, ou seja, o empresário coloca sua própria riqueza no projeto e ela é usada como colateral para tomar emprestado a diferença $k^{*}-b$. A relação entre os dois é $\lambda_{\text {data }}=\lambda_{\text {model }}-1$.

${ }^{26}$ Greeenwood, Sanchez e Wang,2013 mostram que esta variável reflete a eficiência no monitoramento em uma análise entre países.
} 
Na tabela 3.2 podemos verificar que o modelo reproduz bem os momentos da economia brasileira em 2009. No caso da taxa de poupança, colaterais como percentual dos empréstimos e percentual de firmas com crédito temos um ajuste excelente do modelo aos dados. No caso das demais variáveis temos um ajuste muito bom do modelo, com exceção do percentual do emprego nas 5\% maiores firmas e nas $10 \%$ maiores firmas onde o ajuste não é tão bom.

\section{5}

\section{Exercícios realizados e resultados}

Nesta seção, nós avaliamos os efeitos de reduções em cada uma das fricções financeiras separadamente. Neste sentido, nós levamos em consideração mudanças entre estados estacionários da economia quando estes parâmetros são alterados. Além disso, fazemos uma decomposição dos impactos sobre o PIB per capita em termos dos efeitos nas margens intensiva e extensiva.

\subsection{1}

\section{Redução no custo de participação no mercado de crédito}

Nesta subseção avaliamos o impacto de uma redução no custo de participação no mercado de crédito $\psi$ de 0,053 para 0,032 , de tal forma que o percentual de firmas com acesso a crédito passe de 60\% para 95\%. Então o grau de acesso financeiro nesta economia passaria a ser igual à média dos países desenvolvidos. Essa redução eleva o PIB per capita em 3,6\%. Uma redução no custo de participação eleva o PIB per capita por dois motivos. Primeiro, um custo de participação mais baixo permite que um número maior de empresários tenha acesso ao crédito. Segundo, menos recursos são desperdiçados em negociações contratuais improdutivas. Isto permite que empresários muito habilidosos, mas com pouca riqueza, entrem no mercado com firmas mais produtivas. Assim, a TFP se eleva, o que gera um aumento no PIB per capita. Neste contexto, temos uma melhoria na alocação do talento empresarial na economia. Além da redução citada acima, também avaliamos os efeitos de uma redução gradual do custo de 
participação no mercado de crédito $\psi$ de 0,053 para 0 . A figura 3.2 mostra os resultados do exercício.
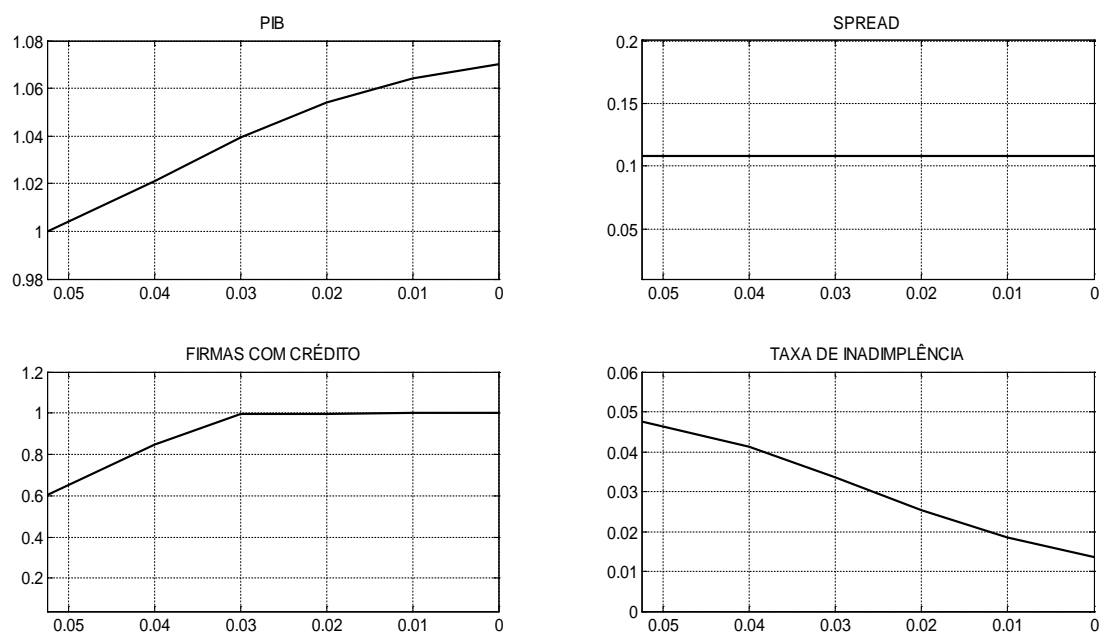

Figura 3.2: Redução do custo de participação no mercado de crédito $(\psi)$ : Efeitos sobre PIB per capita, spread da taxa de juros, percentual de firmas com crédito e taxa de inadimplência.

A eliminação do custo de participação gera um aumento no PIB per capita de cerca de 7\%. Em geral, os países não conseguem eliminar totalmente o custo de participação de forma a atingir um percentual de $100 \%$ das firmas no mercado de crédito. Assim, faz mais sentido avaliar a redução no custo de participação que gera, no Brasil, o mesmo percentual de firmas com crédito dos países desenvolvidos.

O spread da taxa de juros não se altera uma vez que o custo de monitoramento permanece o mesmo e a taxa de alavancagem das firmas não muda. O percentual de firmas com crédito se eleva em função da redução do custo de entrada no mercado de crédito. A taxa de inadimplência se reduz em função do aumento do percentual de empresários com baixa alavancagem no mercado de crédito. Estes empresários nunca ficam inadimplentes e isto reduz a taxa média de inadimplência. 


\section{5 .2}

\section{Relaxamento da restrição de endividamento}

Nesta subseção nós avaliamos os impactos de aumentos no limite de endividamento das firmas. Para tanto, nós elevamos o parâmetro $\lambda$, que controla a restrição de endividamento no modelo, de 2,12 para 3. Isto corresponde, no modelo, a uma redução nos colaterais como percentual dos empréstimos de 95\% para 50\%, o que faria com que o Brasil atingisse a média dos países desenvolvidos em termos de requerimentos de colaterais. Os resultados do exercício são apresentados na figura 3.3.
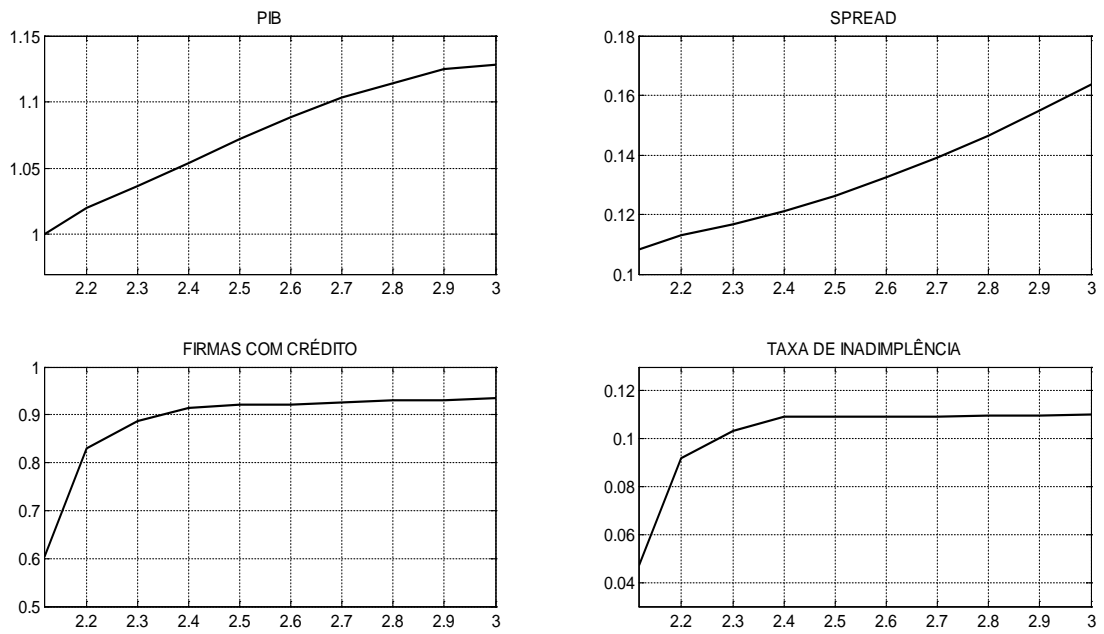

Figura 3.3: Relaxamento da restrição de endividamento $(\lambda)$ : Efeitos sobre PIB per capita, spread da taxa de juros, percentual de firmas com crédito e taxa de inadimplência.

Este aumento no limite de endividamento gera uma elevação de $12 \%$ no PIB per capita. Os efeitos sobre o PIB per capita são gerados por um mecanismo no modelo que eleva a eficiência da economia. A restrição de endividamento para as firmas impede que elas (ou a maioria delas) escolham o nível de capital que maximiza o lucro irrestrito. Dado que o capital contratado depende dos ativos da firma, teremos nesta economia firmas muito produtivas, com ativos baixos, que contratam pouco capital e firmas pouco produtivas, com ativos elevados, que contratam muito capital. Isto gera uma alocação ineficiente do capital e reduz a TFP. Quando se reduz a restrição de endividamento, parte do capital flui das 
firmas menos produtivas para as mais produtivas, o que eleva a TFP e o PIB per capita. Este é o chamado “efeito na margem intensiva”.

O spread da taxa de juros se eleva de $11 \%$ para $16 \%$. Um limite de endividamento maior permite que as firmas tomem mais emprestado o que eleva a taxa de alavancagem das mesmas. Isto gera um aumento no spread médio da economia. O percentual de firmas com crédito se eleva ${ }^{27}$ em função da redução na restrição de endividamento. Isto ocorre dado que o benefício de entrar no mercado de crédito se elevou (devido ao maior endividamento) em relação ao custo de entrada $\psi$. A taxa de inadimplência se eleva em função do aumento no limite de endividamento. Isto permite tomar mais emprestado e contratar mais capital e dessa forma elevar os lucros. Neste contexto, o percentual de empresários com alta alavancagem se eleva na economia. Isto eleva a taxa de inadimplência média da economia.

\section{5 .3}

\section{Redução no custo de monitoramento}

Nesta subseção avaliamos o impacto de uma redução no custo de monitoramento que gera, no modelo, um spread igual à média dos países desenvolvidos (3\%). Esta redução em $\chi$ de 0,85 para 0,2 eleva o PIB per capita em 1,7\%. Isto ocorre em função do aumento na TFP e no estoque de capital devido à redução das ineficiências da economia provocadas pelo custo de monitoramento. Este custo é um "peso morto” dado que não gera renda nem produto para nenhum agente. Devemos notar que neste contexto temos uma forte redução no spread (de $11 \%$ para 3\%) e somente um pequeno aumento do produto per capita. Isto ocorre devido à forte restrição determinada pelo limite de endividamento na economia. Esta restrição impede que os empresários restritos, sem colaterais suficientes para atender às exigências de garantias, aumentem os empréstimos e aproveitem o menor spread.

\footnotetext{
${ }^{27}$ Note que isto não significa que as firmas que entraram no mercado de crédito estão melhores do que antes da alteração no limite de endividamento. Depois da alteração elas estão melhores no regime de crédito do que se continuassem no regime de poupança. Contudo, o aumento no endividamento eleva a taxa de juros e o salário na economia, o que eleva o custo dos fatores de produção utilizados pelas firmas. Então grande parte das firmas está pior depois da alteração e reduz sua produção em relação ao que produzia antes da alteração no limite de endividamento.
} 
Nesta subseção, nós também avaliamos os efeitos de reduções graduais no custo de monitoramento $\chi$ de 0,85 para 0 . A eliminação do custo de monitoramento gera um aumento no PIB per capita de 2,4\%. Os resultados são apresentados na figura 3.4.
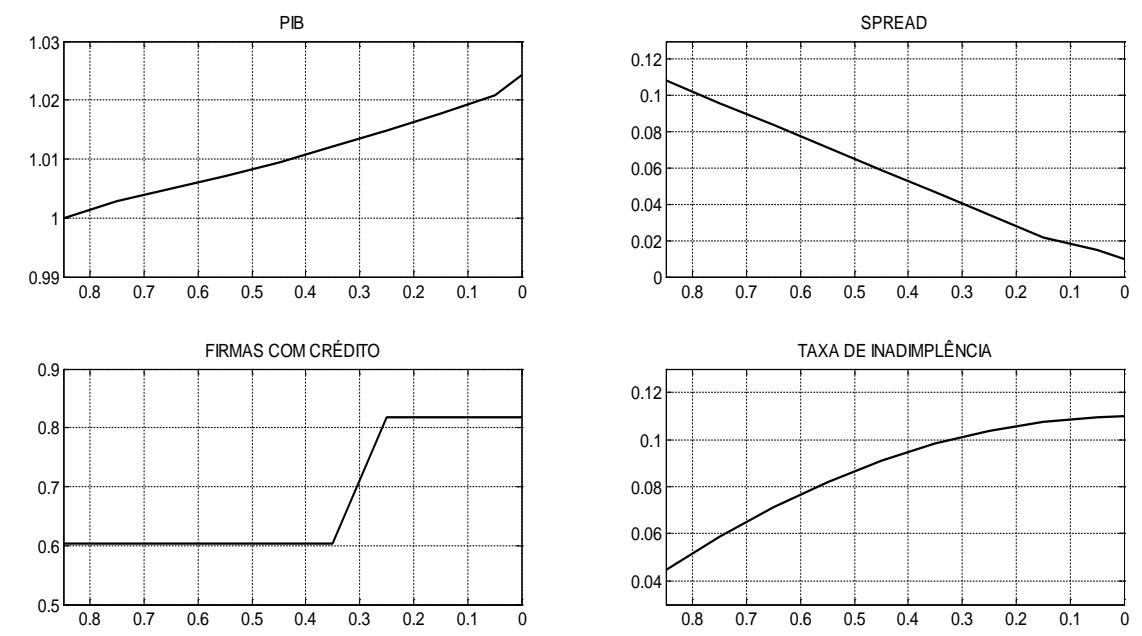

Figura 3.4: Redução no custo de monitoramento (X): Efeitos sobre PIB per capita, spread da taxa de juros, percentual de firmas com crédito e taxa de inadimplência.

A redução em $\chi$ gera uma queda no spread da taxa de juros dado que o spread depende diretamente deste custo. Neste contexto, as firmas irrestritas, que já estavam no regime de crédito, elevam a produção devido à redução dos custos (efeito na margem intensiva). Além disso, novas firmas entram no regime de crédito e expandem a produção, em função da redução do spread (efeito na margem extensiva). Assim, o PIB per capita se eleva adicionalmente.

A redução no spread eleva a demanda por empréstimos e a taxa de alavancagem das firmas. Isto aumenta o percentual de empresários com alta alavancagem na economia (com maior risco) o que eleva a taxa de inadimplência média. O percentual de firmas com crédito na economia se eleva em função da entrada de novas firmas no mercado de crédito devido à redução nas taxas de empréstimos. 


\subsection{4}

\section{Decomposição da taxa de crescimento do PIB per capita}

Nesta subseção nós decompomos o crescimento no PIB per capita gerado pelas reduções nas fricções financeiras (custo de participação no mercado de crédito, custo de monitoramento e limite de endividamento) apresentadas nas subseções anteriores. A taxa de crescimento do PIB per capita é decomposta em três elementos: ganhos na margem extensiva, ganhos na margem intensiva e efeitos de equilíbrio geral no regime de poupança. $\mathrm{O}$ ganho na margem extensiva é definido como o aumento no produto total das firmas, que estavam no regime de poupança antes da alteração na fricção financeira, e entraram no regime de crédito depois da alteração. O ganho na margem intensiva corresponde ao aumento no produto total das firmas que estavam no regime de crédito e permaneceram neste regime depois da redução na fricção financeira. Os efeitos de equilíbrio geral no regime de poupança correspondem à variação no produto total das firmas que estavam no regime de poupança e permaneceram no mesmo regime depois da alteração na fricção financeira.

Nesta subseção decompomos somente os efeitos da eliminação do custo de entrada no mercado de crédito, da eliminação do custo de monitoramento e do aumento no limite de endividamento que levaria o Brasil para o nível de requerimentos de colaterais dos países desenvolvidos. Os resultados são apresentados na tabela 3.3. 
Tabela 3.3: Decomposição da taxa de crescimento do PIB per capita.

\begin{tabular}{|c|c|c|}
\hline & & $\% \mathrm{PIB}$ \\
\hline \multirow[t]{4}{*}{$x$} & Margem extensiva & 1,6 \\
\hline & Margem intensiva & 0,82 \\
\hline & Regime de poupança & $-0,02$ \\
\hline & Total & 2,4 \\
\hline \multirow[t]{4}{*}{$\lambda$} & Margem extensiva & $-0,5$ \\
\hline & Margem intensiva & 13,8 \\
\hline & Regime de poupança & $-1,2$ \\
\hline & Total & 12,1 \\
\hline \multirow[t]{4}{*}{$\psi$} & Margem extensiva & 17,3 \\
\hline & Margem intensiva & $-10,4$ \\
\hline & Regime de poupança & 0,0 \\
\hline & Total & 6,9 \\
\hline
\end{tabular}

No exercício onde eliminamos o custo de monitoramento $\chi$, o aumento do PIB per capita é explicado principalmente pelo efeito na margem extensiva. Contudo o efeito na margem intensiva também é importante. O efeito de equilíbrio geral do regime de poupança não é relevante.

No exercício onde relaxamos a restrição de endividamento (definida por $\lambda$ ), o aumento total é explicado basicamente pelo efeito na margem intensiva. A forte redução na restrição de endividamento eleva fortemente a demanda por capital e a produção das firmas que permanecem no regime de crédito. O efeito na margem extensiva é negativo dado que os benefícios do maior limite de endividamento são superados pelos maiores custos de produção em função do aumento nos preços dos fatores (taxa de juros e salários). Os efeitos de equilíbrio geral no regime de poupança são negativos. Isto ocorre uma vez que os custos de produção das firmas, que permanecem no regime de poupança, se elevam dado que as taxas de juros e os salários aumentam em função da maior demanda destes fatores. Além disso, elas não se beneficiam das melhorias no mercado de crédito uma vez que não possuem acesso a ele.

O aumento no PIB per capita, devido à eliminação do custo de participação no mercado de crédito $\psi$, é o resultado de dois efeitos contrários. O efeito na margem extensiva é um forte aumento no produto total das firmas que 
entram no mercado de crédito depois da eliminação de $\psi$. Isto ocorre uma vez que as firmas se beneficiam do acesso a empréstimos e expandem a produção. Por outro lado, o efeito na margem intensiva é fortemente negativo. As firmas que já estão no regime de crédito se beneficiam pouco da eliminação do custo $\psi$. Além disso, elas são fortemente prejudicadas pelos aumentos nos fatores de produção. Dado que o efeito na margem extensiva supera o efeito na margem intensiva, temos que o resultado é um aumento no PIB per capita.

\section{6}

\section{Conclusão}

Mostramos neste capítulo, que o limite de endividamento, definido pelos colaterais requeridos, é a restrição financeira que mais afeta o PIB per capita no Brasil. Neste caso, uma redução nos colaterais requeridos (para os níveis dos países desenvolvidos) elevaria o PIB per capita em 12\%.

A redução nos custos de entrada no mercado de crédito, que levaria o percentual de firmas com crédito no Brasil para os níveis dos países desenvolvidos, elevaria o PIB per capita em 3,6\%. A redução no custo de monitoramento, que reduziria o spread no Brasil para os níveis dos países desenvolvidos, aumentaria o PIB per capita em 1,7\%.

Estes resultados mostram que o limite de endividamento é a restrição financeira que mais prejudica o PIB per capita no caso brasileiro. Neste sentido, seria importante implementar políticas que elevem o grau de "enforcement” da economia para reduzir os requerimentos de colaterais e elevar o total de empréstimos para as firmas. Estas políticas teriam um efeito maior sobre a economia do que políticas que busquem reduzir o custo de entrada no mercado de crédito ou o spread da taxa de juros. 


\section{4 \\ Impactos macroeconômicos do aprofundamento do crédito no Brasil: o período 2001-2011}

\section{1}

Introdução

Na década passada ocorreu no Brasil um forte processo de aprofundamento do crédito. Entre 2001 e 2011 o crédito total teve um aumento de cerca de 25 pontos percentuais do PIB. O crédito para empresas aumentou de 14,6\% em 2001 para 24,7\% do PIB em 2011. Além disso, o crédito para as famílias passou de 12,6\% em 2001 para 26,9\% do PIB em 2011. Neste contexto os impactos do crédito sobre o PIB per capita podem ser bastante significativos. Os impactos agregados sobre as demais variáveis da economia também podem ser significativos.

A figura 4.1 mostra a evolução do crédito privado entre 2001 e 2011 . O crédito total cresce fortemente entre 2003 e 2011 passando de cerca de 27\% do PIB em 2003 para mais de 50\% em 2011. O crédito privado com recursos livres tem um forte aumento entre 2002 e 2008 passando de cerca de 15\% do PIB para 30\% do PIB. A partir de 2008 o crédito com recursos livres se estabiliza. O crédito privado com recursos direcionados se eleva a partir de 2005 passando de $10 \%$ para mais de $20 \%$ do PIB. 


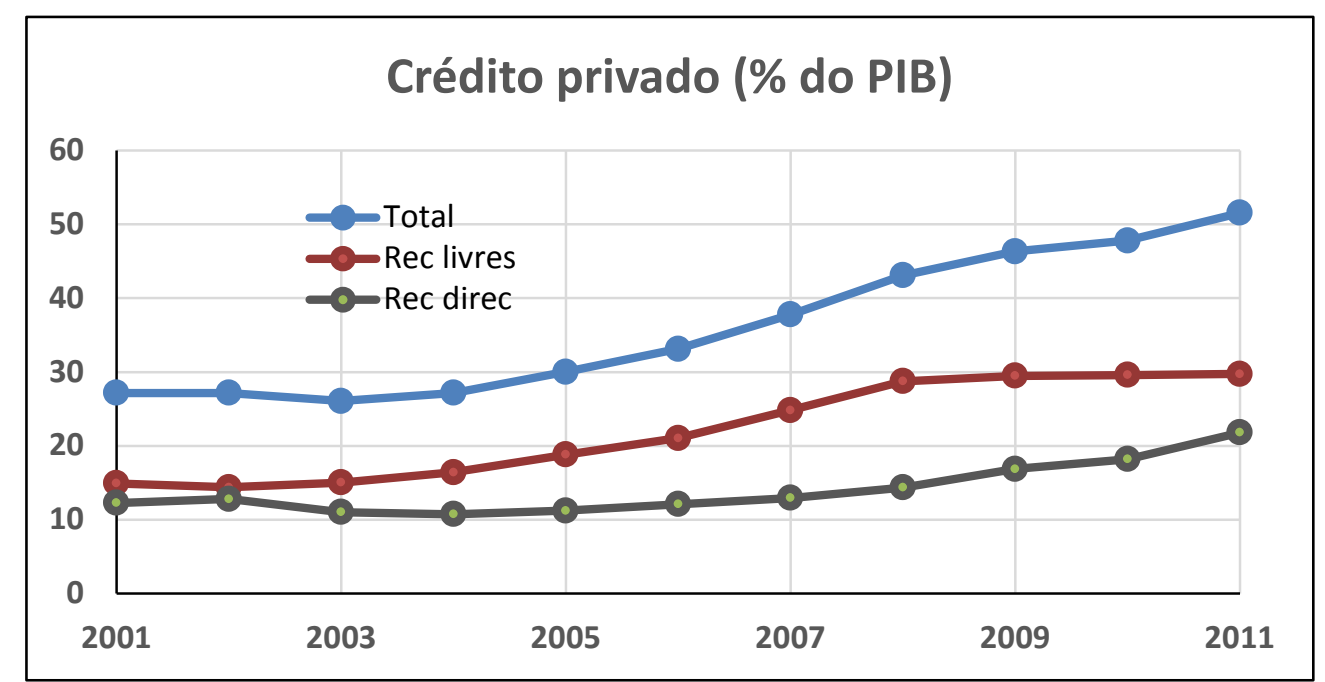

Figura 4.1: Crédito privado como proporção do PIB.

Fonte: BACEN.

O crédito com recursos livres é aquele que é negociado livremente no mercado sem taxas de juros subsidiadas. $\mathrm{O}$ crédito com recursos direcionados corresponde ao crédito com taxas de juros subsidiadas e vinculado a bancos ou programas governamentais.

A figura 4.2 mostra a evolução do crédito privado com recursos livres como proporção do PIB. Entre 2001 e 2011 o crédito com recursos livres dobrou, passando de 15\% do PIB para 30\% do PIB. O crédito para as firmas se elevou, passando de 10\% em 2001 para 15\% do PIB em 2011. O crédito para as famílias triplicou no período, passando de 5\% do PIB em 2001 para 15\% do PIB em 2011. Estes dados demonstram o crescimento expressivo do crédito no período.

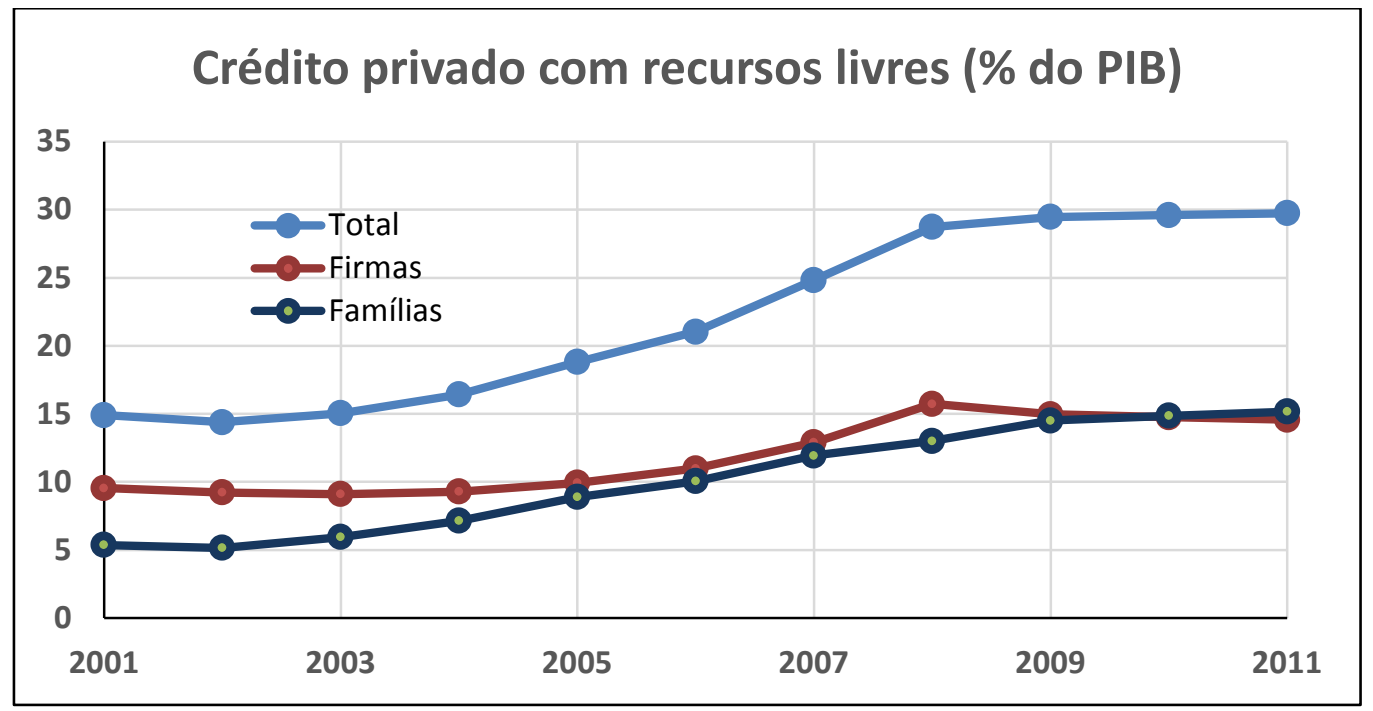

Figura 4.2: Crédito privado com recursos livres como proporção do PIB.

Fonte: BACEN.

O crédito para as firmas corresponde aos recursos emprestados para as pessoas jurídicas do setor privado. O crédito para as famílias corresponde aos recursos emprestados para as pessoas físicas. 
Entre os fatores que contribuíram para a elevação do crédito podemos destacar: a adoção do crédito consignado, as alterações na legislação do crédito para automóveis, as alterações na legislação do crédito imobiliário e as alterações na Lei de Falências ${ }^{28}$. O crédito consignado em folha de pagamento é uma modalidade de empréstimo em que o devedor sofre um desconto no salário para pagar sua dívida com o banco. Apesar da dívida ser do empregado, o empregador retém parte do salário correspondente à prestação devida e transfere o valor para o banco. O limite máximo de retenção corresponde a 30\% do valor do salário. Segundo Mora (2015), a legislação adotada em 2003 permitiu um forte aumento do crédito consignado no Brasil.

No caso do crédito para aquisição de automóveis, alterações na legislação passaram a permitir que o banco retome rapidamente o automóvel dado em garantia do empréstimo em caso de inadimplência. Antes dessas alterações, os bancos demoravam em média de dois a três anos para retomar o automóvel (que após este período já estava bastante depreciado). Atualmente em poucas semanas o banco consegue retomar o automóvel ${ }^{29}$. Assunção, Silva e Benmelech (2012) apontam que as mudanças nas regras de alienação fiduciária permitiram a expansão do crédito para aquisição de automóveis.

Segundo Mendonça (2013), no caso do crédito imobiliário, a criação da figura jurídica do patrimônio de afetação, que diferencia os recursos captados para o financiamento da obra do patrimônio da incorporadora, permitiu a redução do risco de inadimplência. A introdução das letras de crédito imobiliário e das cédulas de crédito imobiliário também foram importantes para o aumento dos financiamentos. Por último, a consolidação da alienação fiduciária do bem imóvel gerou maior segurança jurídica nos empréstimos.

Segundo Mora (2015), a aprovação da nova Lei de Falências reduziu o risco do emprestador, levando ao aumento das operações de crédito para as pessoas jurídicas. A antiga Lei de Falências (Decreto-Lei no 7.661, de 21 de junho de 1945) priorizava o pagamento das dívidas trabalhistas e fiscais, sendo as demais dívidas relegadas a um terceiro plano. Portanto, o direito dos credores não era adequadamente protegido. Além disso, a lei anterior era incapaz de impedir a

\footnotetext{
${ }^{28}$ Vide Mora (2015).

${ }^{29}$ Vide Mora (2015).
} 
falência de empresas economicamente viáveis, além de suscitar problemas na sucessão, que desvalorizavam a massa falida em termos de preços de mercado ${ }^{30}$.

A nova Lei de Falências (Lei no 11.101, de 9 de fevereiro de 2005) buscou equacionar estes problemas. O crédito trabalhista passou a se limitar a 150 salários mínimos (SMs) e o crédito segurado passou a ter precedência sobre o crédito fiscal no recebimento de recursos da firma em processo de falência. Além disso, o crédito não segurado passou a ter precedência sobre algumas categorias de crédito fiscal ${ }^{31}$. Estas medidas reduziram o risco do credor em caso de falências. Além disso, a nova Lei também estabeleceu um ambiente propenso à recuperação de empresas viáveis economicamente. Araújo e Funchal (2009) apontam que, embora o spread médio das operações de crédito não tenha se reduzido, o volume de crédito para as firmas cresceu expressivamente devido à implantação da nova Lei de Falências.

Todas estas alterações na legislação permitiram uma redução do risco de inadimplência o que contribuiu para o forte aumento do crédito como proporção do PIB ocorrido no período. Neste contexto, o objetivo do nosso trabalho é avaliar os impactos macroeconômicos do aumento do crédito no Brasil no período 20012011. Em termos mais específicos, nossa meta principal é avaliar os impactos do aumento do crédito sobre o PIB per capita. Para realizar nosso objetivo utilizamos uma versão do modelo de crescimento neoclássico com agentes heterogêneos e restrições de crédito. O modelo é calibrado para a economia brasileira e fazemos um exercício de simulação onde avaliamos os impactos do aumento do crédito com recursos livres ${ }^{32}$. A contribuição do trabalho para a literatura no Brasil é utilizar uma modelagem, com um mecanismo onde a elevação do crédito gera impactos sobre a TFP e o PIB per capita, para avaliar o período de aprofundamento do crédito no Brasil.

A figura 4.3 mostra a evolução do crédito privado com recursos livres e do PIB per capita. O PIB per capita passou de aproximadamente R\$18 mil em 2001

\footnotetext{
${ }^{30}$ Vide Araújo e Funchal (2009).

${ }^{31}$ Vide Mora (2015).

${ }^{32}$ Estes recursos são emprestados com taxas de juros livremente negociadas no mercado. Então não avaliaremos o impacto do crédito direcionado, que é obtido com taxas de juros subsidiadas. Isto significa, basicamente, que não avaliaremos os efeitos do crédito fornecido pelo Banco Nacional de Desenvolvimento Econômico e Social (BNDES). Para avaliar os efeitos do crédito subsidiado seria necessário modelar a economia com um agente que empresta com taxas de juros subsidiadas e se financia por meio de impostos. Como não era nosso objetivo fazer este tipo de análise neste trabalho resolvemos não avaliar o crédito subsidiado.
} 
para mais de R\$24 mil em 2011, correspondendo a um aumento de mais de 33\% no período.

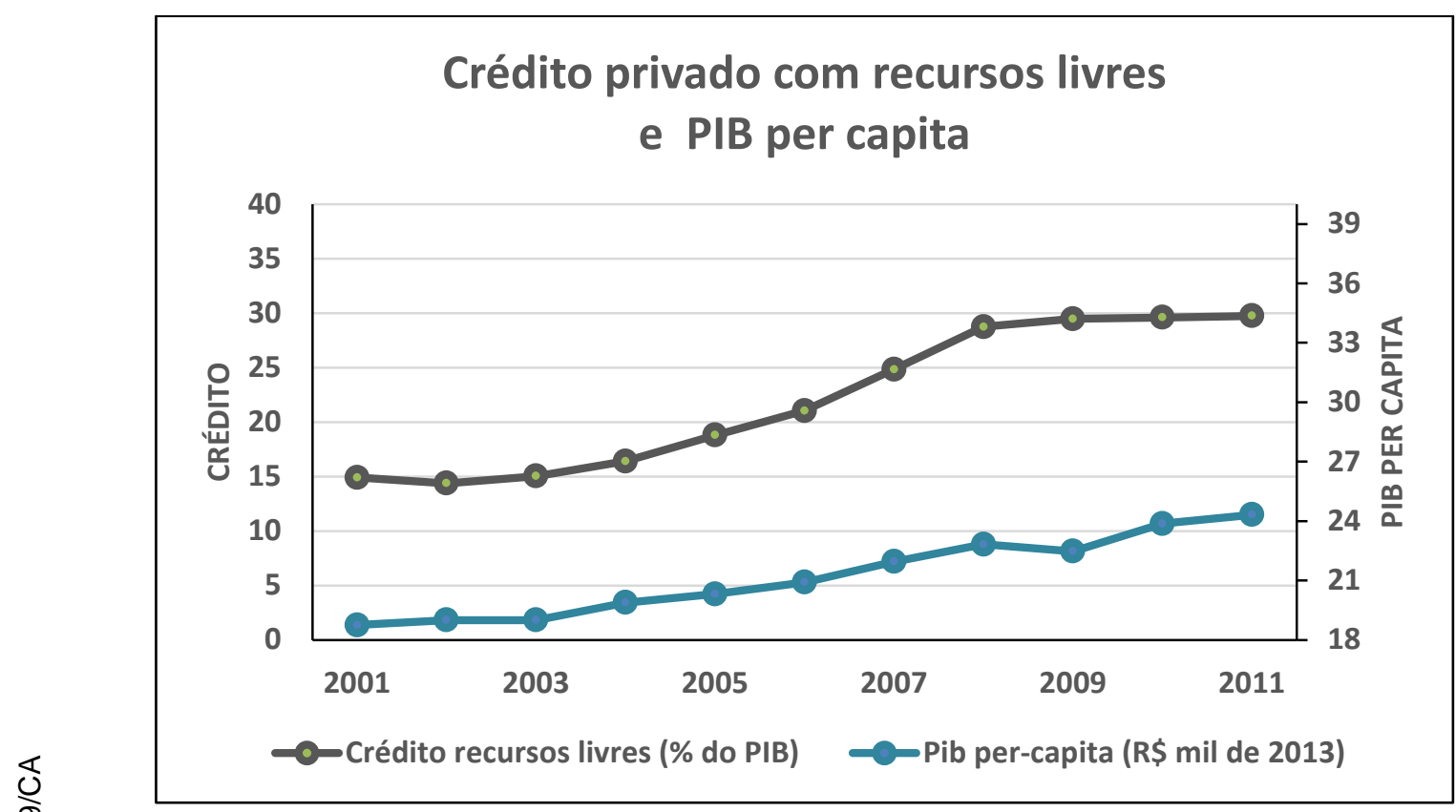

Figura 4.3: Crédito privado com recursos livres e PIB per capita.

Fonte: BACEN e IPEADATA.

Nós utilizamos uma versão do modelo de crescimento neoclássico com famílias heterogêneas e firmas heterogêneas. As famílias são heterogêneas na quantidade de ativos que possuem e no nível de habilidade (que denominamos aqui de habilidade empresarial). O modelo inclui escolha ocupacional, neste caso, em cada período, os indivíduos escolhem entre trabalhar em troca de um salário ou operar uma tecnologia específica do indivíduo. Nós denominamos a segunda escolha de ocupação de atuação como um “empresário”, onde ele opera uma “firma”. Nesta economia os únicos ativos são um título livre de risco de um período (ativo financeiro) e o capital físico (ativo real). Um intermediário financeiro perfeitamente competitivo vende títulos, lastreados pelo estoque de capital físico, para as famílias e aluga capital para os empresários. Os indivíduos podem também emitir títulos (IOU privados) para outros indivíduos sujeitos às restrições de quantidade. O modelo possui restrições de crédito para as firmas e para os consumidores. O montante de capital que a firma pode contratar depende do valor dos ativos que ela possui (colaterais). Os indivíduos são restritos por um 
nível máximo de crédito para o consumo. O modelo não possui incerteza agregada.

O modelo possui um mecanismo onde as reduções nas restrições de crédito para as firmas elevam a TFP e o PIB. A restrição de crédito para as firmas impede que elas (ou a maioria delas) escolham o nível de capital que maximiza o lucro irrestrito. Dado que o capital contratado depende dos ativos da firma, teremos nesta economia firmas muito produtivas com ativos baixos que contratam pouco capital e firmas pouco produtivas com ativos elevados que contratam muito capital. Isto gera uma alocação ineficiente do capital e reduz a TFP. Quando se reduz a restrição de crédito, parte do capital flui das firmas menos produtivas para as mais produtivas o que eleva a TFP e o PIB.

A restrição de crédito para as firmas também impede que indivíduos com alta habilidade e ativos baixos se tornem empresários, pois eles não possuem colaterais suficientes para obter empréstimos e contratar o capital necessário. Isto gera uma alocação ineficiente do talento empresarial e reduz a TFP. O relaxamento da restrição de crédito permite que indivíduos de alta habilidade e ativos baixos se tornem empresários o que eleva adicionalmente a TFP e o produto.

O modelo foi calibrado para reproduzir momentos da economia brasileira em 2001. Uma parte dos parâmetros foi fixada levando em conta dados da economia brasileira e a literatura no Brasil. O restante dos parâmetros foi calibrado de forma a reproduzir no modelo momentos específicos da economia brasileira em 2001. Os momentos reproduzidos no modelo foram o percentual de empresários na economia, taxa de juros reais, percentual da renda mantido pelos 5\% mais ricos, crédito para as firmas como proporção do PIB e crédito ao consumidor como proporção do PIB. O modelo reproduz bem os dados para 2001 no Brasil.

Neste texto realizamos dois exercícios. No primeiro avaliamos os efeitos do aumento do crédito para as firmas sobre a economia. No segundo avaliamos os efeitos do aumento do crédito para as firmas e para os consumidores conjuntamente. No primeiro exercício simulamos no modelo o aumento ocorrido no crédito para as firmas de 10\% do PIB em 2001 para cerca de 15\% do PIB em 2011. Para tanto calibramos a trajetória do parâmetro que controla a restrição de crédito para as firmas de forma a reproduzir no modelo a trajetória de aumento do 
crédito para as empresas ocorrida no período. A partir disto, avaliamos os impactos sobre o PIB per capita e demais variáveis no modelo gerados por este aumento no crédito.

Os resultados mostram que o aumento no crédito para as firmas gera um aumento de 1,5\% no PIB per capita no período. Além disso, a TFP aumenta cerca de $0,4 \%$. A redução na restrição de crédito permite que as firmas operem com um nível de capital e produção mais eficientes. Isto eleva a produtividade das firmas e consequentemente a TFP. A entrada de firmas mais produtivas com empresários mais habilidosos, eleva adicionalmente a TFP. O aumento da TFP, do estoque de capital e do trabalho geram a trajetória de crescimento do PIB per capita, que se eleva $1,5 \%$ no período.

Considerando os dados, o modelo explica cerca de 7\% do aumento do PIB per capita no período. Além disso, supondo uma tendência de crescimento de longo prazo da economia de $2 \%$ ao ano, o modelo explicaria mais de $20 \%$ do crescimento do PIB não explicado pela tendência.

No segundo exercício, avaliamos o efeito conjunto do aumento do crédito para as firmas e para o consumidor. Neste exercício simulamos no modelo o aumento ocorrido no crédito para as firmas de 10\% do PIB em 2001 para cerca de 15\% do PIB em 2011 em conjunto com o aumento ocorrido no crédito para o consumidor de cerca de 5\% para cerca de 15\% do PIB. Para tanto calibramos a trajetória do parâmetro que controla a restrição de crédito para as firmas de forma a reproduzir no modelo a trajetória de aumento do crédito para as empresas ocorrida no período. Além disso, calibramos a trajetória do parâmetro que controla a restrição de crédito para o consumidor de forma a reproduzir no modelo a trajetória de elevação ocorrida no crédito para o consumidor. A partir disto, avaliamos os impactos sobre o PIB per capita e demais variáveis no modelo gerados por este aumento no crédito. Neste exercício, o PIB per capita atinge um crescimento de $1,5 \%$ no período, como no exercício anterior. Além disso, o consumo per capita se eleva $1 \%$ no período.

O restante do texto é organizado da seguinte forma: a seção 2 fornece uma breve revisão da literatura relacionada ao trabalho, a seção 3 descreve o modelo utilizado, a seção 4 apresenta a calibração do modelo, a seção 5 descreve os resultados dos exercícios realizados e por fim, na seção 6 apresentamos as conclusões. 


\section{2 \\ Revisão da literatura}

Uma literatura crescente tem enfatizado os impactos agregados e distributivos da intermediação financeira em modelos de escolha ocupacional e imperfeições no mercado financeiro. Esta estrutura teórica foi introduzida por Banerjee e Newman (1993) para analisar o processo de desenvolvimento econômico. Lloyd-Ellis e Bernhardt (2000) estendem o modelo para explicar a desigualdade de renda e a existência de uma curva de Kuznets. Quadrini (2000) estende a estrutura para avaliar os efeitos do empreendedorismo sobre a poupança agregada e a distribuição de riqueza na economia. Cagetti e De Nardi (2006) estendem o modelo utilizando gerações superpostas e mostram que a introdução de um motivo "herança" gera poupanças ao longo da vida mais consistentes com os dados. Nesses estudos, uma melhoria da intermediação financeira conduz a uma intensificação do empreendedorismo na economia, aumento da produtividade, elevação dos salários e aumento do produto.

Uma literatura relacionada tem encontrado impactos consideráveis da melhoria da intermediação financeira sobre a produtividade agregada e o PIB per capita. Nosso trabalho está inserido nessa literatura que utiliza versões do modelo de crescimento neoclássico com agentes heterogêneos e restrições de crédito exógenas para avaliar o impacto do crédito sobre a TFP e o PIB per capita (Buera e Shin, 2013; Curtis, 2016 e Guerrieri e Lorenzoni, 2011). Guerrieri e Lorenzoni (2011) utilizam um modelo próximo de Aiyagari (1994), com oferta de trabalho endógena e sem capital. Os autores mostram como uma crise de crédito (para o consumidor) pode gerar recessão com baixa taxa de juros devido ao repagamento de dívidas e aumento da poupança precaucional. Buera e Shin (2013) utilizam um modelo com escolha ocupacional para avaliar os impactos de longo prazo das restrições de crédito e a eliminação de distorções na economia na forma de impostos sobre o lucro. Eles avaliam reformas econômicas que levaram ao "milagre do crescimento" no leste asiático. Moll (2014) mostra que os impactos das fricções financeiras sobre o PIB e a TFP dependem da persistência dos choques idiossincráticos. 
Nosso trabalho está bastante relacionado a uma literatura que utiliza versões do modelo de crescimento neoclássico com agentes heterogêneos, “enforcement” limitado e restrições de crédito endógenas (Antunes, Cavalcanti e Villamil, 2008, 2014; Buera, Kaboski e Shin, 2011). Buera, Kaboski e Shin (2011) avaliam a relação entre TFP (agregada e setorial) e desenvolvimento financeiro entre países. Em seu modelo setores com grandes escalas de produção (como a manufatura) sofrem mais os efeitos das restrições de crédito uma vez que possuem maiores necessidades financeiras. Mostram que as restrições de crédito explicam uma parte substancial das diferenças observadas entre países no produto por trabalhador, TFP agregada e TFP setorial.

Além disso, nosso texto se relaciona com uma literatura que utiliza versões mais simples do modelo de crescimento neoclássico com agentes heterogêneos e restrições de crédito. Estas versões mais simples permitem utilizar modelos estruturais onde parte dos parâmetros são estimados (Jeong e Townsend, 2008; Giné e Tonwsend, 2004). Giné e Townsend (2004) avaliam os efeitos sobre o crescimento econômico e a distribuição da renda da liberalização financeira observada na Tailândia entre 1976 e 1996. Eles utilizam um modelo de equilíbrio geral mais simplificado (o modelo de Lloyd-Ellis e Bernhardt, 2000) e estimam parte dos parâmetros por máxima verossimilhança. Os resultados do trabalho mostram que a expansão do crédito foi fundamental para a trajetória de crescimento observada na Tailândia no período considerado.

Nosso trabalho também está relacionado a uma literatura sobre “misallocation” (Hsieh e Klenow, 2009; Midrigan e Xu, 2014), dado que na modelagem que utilizamos, o aumento da eficiência na alocação dos recursos é importante para explicar os efeitos do crédito sobre a TFP.

Por fim, o trabalho está relacionado a uma literatura empírica que busca avaliar os impactos do desenvolvimento financeiro sobre o crescimento econômico. Em geral, esta literatura utiliza variáveis instrumentais, mínimos quadrados em dois estágios e painel dinâmico (King e Levine,1993; Levine, Loayza e Beck, 2000). King e Levine (1993) encontram que o nível de desenvolvimento financeiro de um país contribui para predizer sua taxa de crescimento econômico para os próximos 10 anos e para os próximos 30 anos. Eles examinam uma “cross-section” de 80 países para o período 1960-1989 e 
utilizam regressões com variáveis instrumentais e mínimos quadrados em dois estágios.

No Brasil temos poucos trabalhos que utilizam versões do modelo de crescimento neoclássico com agentes heterogêneos e restrições de crédito (Antunes, Cavalcanti e Villamil, 2008, 2014). Antunes e outros (2008) mostram que as fricções financeiras explicam grande parte da diferença na renda per capita entre Brasil e EUA. Além disso, temos poucos trabalhos no Brasil que avaliam os impactos macroeconômicos do aumento do crédito na década passada. Carvalho e outros (2014) utilizam um modelo DSGE novo keynesiano com fricções financeiras para avaliar os impactos da elevação do crédito no período 2004-2012 no Brasil. Eles encontram efeitos reduzidos do crédito sobre o PIB.

O modelo utilizado em nosso trabalho é muito próximo de Buera e Shin (2013), contudo utilizamos duas restrições de crédito (uma sobre as firmas e outra sobre os consumidores) enquanto Buera e Shin (2013) utiliza somente uma restrição sobre as firmas. Além disso, avaliamos o aumento do crédito ocorrido no período e não a eliminação de alíquotas de impostos (que representam os impostos e as demais distorções na economia) como fazem Buera e Shin (2013).

A nossa contribuição para a literatura é usar esta modelagem, que utiliza uma versão do modelo de crescimento neoclássico com agentes heterogêneos, restrições de crédito e escolha ocupacional, para avaliar o período de aprofundamento do crédito no Brasil (2001-2011).

\section{3 \\ Modelo}

Nós utilizamos uma versão do modelo de crescimento neoclássico com famílias heterogêneas e firmas heterogêneas. As famílias são heterogêneas na quantidade de ativos que possuem e no nível de habilidade (que denominamos aqui de habilidade empresarial). O modelo inclui escolha ocupacional (como em Lucas,1978), neste caso, o indivíduo decide ser trabalhador ou empresário de acordo com os incentivos da economia. Os agentes possuem somente um título de risco de um período para emprestar ou tomar emprestado (economia com mercados incompletos). O modelo possui restrições de crédito para as firmas e 
para os consumidores. O montante de capital que a firma pode contratar depende do valor dos ativos que ela possui (colaterais). Os indivíduos são restritos por um nível máximo de crédito para o consumo. O modelo não possui incerteza agregada.

\section{Heterogeneidade e demografia}

Os indivíduos ${ }^{33}$ vivem indefinidamente e são heterogêneos em relação aos seus ativos $a$ e sua habilidade empresarial $e$. Os ativos são escolhidos a cada período por decisões de poupança “forward-looking”. A habilidade empresarial de um indivíduo segue uma cadeia de Markov.

Nós denotamos por $P\left(e, e^{\prime}\right)$ a função de transição do processo de Markov que determina a evolução da habilidade empresarial. A função de distribuição conjunta de habilidade empresarial e ativos no início do período t é denotada por $G_{t}(a, e)$. O tamanho da população da economia é normalizado para um e não existe crescimento populacional. Nesta economia existe uma infinidade de indivíduos de massa total igual a um.

\section{Preferências}

Os indivíduos descontam sua utilidade futura usando o mesmo fator de desconto $\beta$. As preferências sobre os planos contingentes para a sequência de consumo de um indivíduo no período $t$ são dadas por:

$$
E_{t} \sum_{s=t}^{\infty} \beta^{s-t} u\left(c_{s}\right)
$$

Onde a função de utilidade instantânea possui aversão relativa ao risco constante:

$$
u(c)=\frac{c^{1-\gamma}}{1-\gamma}
$$

\section{Tecnologia}

Em cada período $t$, os indivíduos escolhem entre trabalhar em troca de um salário ou operar uma tecnologia específica do indivíduo. Nós denominamos a segunda escolha de ocupação de atuação como um “empresário”, onde ele opera uma "firma”. Supomos que um empresário com produtividade $e$ que usa $k$

\footnotetext{
${ }^{33}$ Neste modelo os agentes individuais são famílias formadas por um único indivíduo. Neste contexto família e indivíduo são sinônimos.
} 
unidades de capital e contrata $l$ unidades de trabalho produz de acordo com a função de produção $f(e, k, l)$. Esta função é estritamente crescente em todos os argumentos e estritamente côncava no capital e trabalho, com $f(0, k, l)=0$. A função de produção específica do empresário de habilidade $e$ é dada por:

$$
f(e, k, l)=e\left(k^{\alpha} l^{1-\alpha}\right)^{1-v}
$$

Onde $v$ é o "share" do produto destinado ao empresário e 1-v é o parâmetro do "span-of-control” de Lucas (1978). Deste modo, 1-v representa a parte do produto destinada para os fatores variáveis. Desta parcela, uma fração $\alpha$ é destinada para o capital e uma fração 1- $\alpha$ é destinada ao trabalho. Note que a função de produção possui retornos decrescentes de escala nos fatores variáveis (capital e trabalho).

\section{Mercado financeiro}

Nesta economia os únicos ativos são um título livre de risco de um período (ativo financeiro) e o capital físico (ativo real). Um intermediário financeiro perfeitamente competitivo vende títulos, lastreados pelo estoque de capital físico, para as famílias e aluga capital para os empresários. Os indivíduos podem também emitir títulos (IOU privados) para outros indivíduos sujeitos às restrições de quantidade. Em equilíbrio, a demanda líquida por títulos dos indivíduos é igual ao estoque de capital físico. O retorno dos títulos livres de risco (a taxa de juros da economia) é $r$. A condição de lucro zero do intermediário implica que o custo de aluguel do capital é $r+\delta$, onde $\delta$ é a taxa de depreciação.

A quantidade de capital que um empresário pode contratar $k$ é limitada por uma restrição de colateral:

$$
\begin{aligned}
& k \leq \lambda a \\
& a>0
\end{aligned}
$$

Onde $a$ é a quantidade de ativos financeiros do indivíduo e $\lambda$ mede o grau de restrição de crédito para as empresas. Note que ele precisa manter ativos financeiros positivos para obter crédito no montante de $k$. O mesmo $\lambda$ se aplica a todos na economia. Esta especificação está de acordo com o resultado dos modelos com contratos com “enforcement” limitado onde o montante de crédito é limitado pela riqueza financeira do empresário. Esta especificação tem sido usada extensamente na literatura sobre fricções financeiras e escolha ocupacional. 
Os indivíduos também podem tomar emprestado para consumir. Como em Aiyagari (1994) existe um limite de crédito para o consumo de $b$. Neste caso a restrição é dada por:

$$
a \geq-b
$$

Se $a$ é negativo significa que o indivíduo está tomando emprestado para suavizar o seu consumo ao longo do tempo e o máximo que ele pode tomar emprestado é $b$. Os indivíduos que decidem ser empresários não tomam crédito para o consumo pois precisam manter $a$ positivo. Somente os trabalhadores tomam crédito para consumir (quando isto é ótimo para eles). Um indivíduo pode emprestar para outro para ele consumir, contudo não pode emprestar para ele virar empresário.

\section{O problema do indivíduo}

Nesta economia um indivíduo (família) tem que tomar várias decisões a cada período $t$. No início do período ele sabe o valor dos seus ativos e seu nível de habilidade. Então ele calcula quanto receberia se fosse empresário e quanto receberia se fosse trabalhador e escolhe a ocupação com maior remuneração. Depois, se ele é um empresário, escolhe as demandas ótimas de capital e trabalho. Posteriormente, ele decide o consumo e os ativos do próximo período. No final do período ele sofre um choque na sua habilidade e retira uma nova habilidade $e$ ' de uma cadeia de Markov. No início do período seguinte o indivíduo conhece o novo valor dos seus ativos e sua nova habilidade. Então ele decide a ocupação do período seguinte e toma as demais decisões, ou seja, a cada período o agente toma todas as decisões mencionadas.

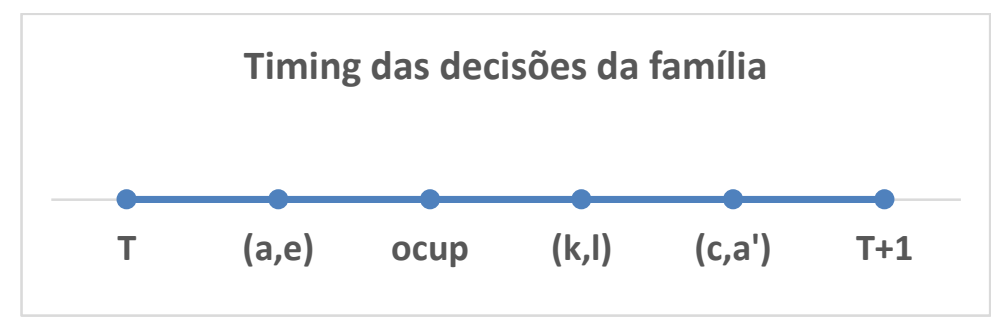

Figura 4.4: Timing das decisões. 
A representação recursiva do problema do indivíduo é dada pela equação de Bellman ${ }^{34}$ :

$$
v(a, e)=\max _{c, a^{\prime} \geq-b} u(c)+\beta E\left[v\left(a^{\prime}, e^{\prime}\right) \mid e\right]
$$

Sujeito à:

$$
c+a^{\prime} \leq \max \{w, \pi(a, e ; w, r)\}+(1+r) a
$$

Onde o salário de equilíbrio $w$ e a taxa de juros $r$ são dadas, e $\pi(a, e ; w, r)$ é a função lucro indireta. Esta função é definida como:

$$
\pi(a, e ; w, r)=\max _{l, k \leq \lambda a}\{f(e, k, l)-w l-(\delta+r) k\}
$$

As funções de demanda por insumos são denotadas por $l(a, e ; w, r)$ e $k(a, e ; w, r)$. Note que o indivíduo decide a quantidade de ativos para o próximo período ( $a$ ') levando em conta a restrição de crédito para consumo. Além disso, o empresário decide a quantidade ótima de capital sujeito à restrição de crédito para as firmas.

A renda do indivíduo na restrição orçamentária $(\max \{w, \pi(a, e ; w, r)\})$ é definida pela escolha ocupacional. Uma família com ativos a e habilidade empresarial $e$ escolhe ser um empresário somente se os lucros forem superiores à renda do trabalho $w$. Neste caso, um indivíduo com habilidade $e$ decide ser um empresário se o seu montante de ativos correntes $a$ for maior que um nível crítico de ativos $\underline{a}(e)$, onde $\underline{a}(e)$ resolve:

$$
\pi(\underline{a}(e), e ; w, r)=w
$$

Então, com mercados de capitais imperfeitos, indivíduos com uma dada produtividade empresarial escolhem se tornar empresários somente se eles são ricos o suficiente para superar a restrição de colaterais e operar seu negócio em uma escala lucrativa.

\section{O equilíbrio competitivo recursivo}

O equilíbrio competitivo recursivo desta economia consiste de sequências de funções valor e funções políticas, sequências de funções distribuição da

\footnotetext{
${ }^{34}$ Dado o timing das decisões do indivíduo, o problema de encontrar as sequências de $c$ e $a$ ' que maximizam a utilidade intertemporal neste modelo é equivalente ao problema do indivíduo em Aiyagari(1994). Acemoglu (2009) demostra que o problema do indivíduo em Aiyagari (1994) pode ser escrito na forma recursiva (o princípio da otimalidade de Bellman é válido neste caso). Dessa forma, o problema do indivíduo em nosso modelo pode ser escrito na forma recursiva.
} 
população em termos de ativos e habilidade $\left(G_{t}\left(a_{t}, e_{t}\right)\right)$ e sequências de preços (dada a função distribuição inicial):

$$
\begin{aligned}
& \left\{V\left(a_{t}, e_{t}, G_{t}\right), c\left(a_{t}, e_{t}, G_{t}\right), a^{\prime}\left(a_{t}, e_{t}, G_{t}\right)\right\}_{t=0}^{\infty} \\
& \left\{l\left(a_{t}, e_{t}, w_{t}, r_{t}\right), k\left(a_{t}, e_{t}, w_{t}, r_{t}\right)\right\}_{t=0}^{\infty} \\
& \left\{G_{t}\left(a_{t}, e_{t}\right)\right\}_{t=1}^{\infty} \\
& \left\{w_{t}, r_{t}\right\}_{t=0}^{\infty}
\end{aligned}
$$

Tais que:

1) Dados os preços, as funções valor e políticas resolvem o problema do indivíduo.

2) Os mercados de trabalho, capital e bens se equilibram:

$$
\begin{aligned}
& L_{t} \equiv \int_{e \underline{a}\left(e, w_{t}, r_{t}\right)}^{\infty} l\left(a, e, w_{t}, r_{t}\right) d G_{t}(a, e)=\int_{e}^{\underline{a}\left(e, w_{t}, r_{t}\right)} \int_{-\infty}^{d} d G_{t}(a, e) \\
& K_{t} \equiv \int_{e \underline{a}\left(e, w_{t}, r_{t}\right)} \int_{k}^{\infty} k\left(a, e, w_{t}, r_{t}\right) d G_{t}(a, e)=\int_{e} \int_{a} a_{t} d G_{t}(a, e)
\end{aligned}
$$

A equação 11 demonstra o equilíbrio no mercado de trabalho. O lado esquerdo da equação representa a demanda agregada de trabalho e o lado direito representa a oferta agregada de trabalho. A equação 12 representa o equilíbrio no mercado de capital. No lado esquerdo da equação temos a demanda de capital e no lado direito temos a oferta de capital.

3) A distribuição da população em termos de ativos e habilidade empresarial evolui de acordo com o mapeamento de equilíbrio:

$$
G_{t+1}(a, e)=\int_{\hat{e}} \int_{\left\{\hat{a}: a^{\prime}(\hat{e}, \hat{a}) \leq a\right\}}\left\{\int_{e^{*} \leq e} d P\left(\hat{e}, e^{*}\right)\right\} d G_{t}(\hat{a}, \hat{e})
$$

\section{4}

\section{Calibração}

A habilidade empresarial (e) segue um processo auto regressivo com inovações normais:

$$
\log e^{\prime}=\rho \log e+\varepsilon, \quad \operatorname{com} \varepsilon \sim N\left(0, \sigma^{2}\right)
$$

Este processo foi aproximado por uma cadeia de Markov com 40 estados segundo o método de Tauchen, 1986. 
Supomos um processo altamente persistente ${ }^{35}$ e o procedimento adotado foi utilizar $\rho=0,98$ seguindo Buera e Shin (2011). O parâmetro $\sigma^{2}$ é calibrado para que o modelo reproduza o percentual da renda retido pelos 5\% mais ricos da população no ano de 2001. Este percentual foi de 33,7\% em 2001 segundo dados da PNAD.

Utilizamos um coeficiente de aversão relativa ao risco de $\gamma=2$. A literatura no Brasil utiliza valores entre 1 e 4 (exemplo: Ellery e Bugarin, 2003, $\gamma=1,43$ ). A taxa de depreciação foi fixada em $\delta=0,037$ conforme calculado por Morandi e Reis (2004). Estes autores utilizam o método do estoque perpétuo para calcular a série de estoque de capital e a depreciação para o período 1950-2002. A participação do trabalho na renda total foi calculada a partir dos dados das Contas Nacionais do IBGE. Esta participação inclui rendimentos do trabalho e rendimento misto (dos autônomos).

Os cinco parâmetros restantes foram calibrados conjuntamente para reproduzir no modelo cinco momentos da economia brasileira em 2001. O percentual de empresários na população, uma taxa de juros reais de $4 \%$ a.a., o percentual da renda dos 5\% mais ricos, o crédito para empresas como proporção do PIB e o crédito ao consumidor como proporção do PIB. Os parâmetros são calibrados conjuntamente, contudo cada parâmetro específico está mais diretamente relacionado a um momento específico.

\footnotetext{
${ }^{35}$ Com um processo altamente persistente um indivíduo habilidoso consegue obter rendimentos elevados por um período maior de tempo, antes que perca esta habilidade. Isto permite que ele poupe recursos suficientes para superar a restrição de crédito e se tornar empresário por meio do autofinanciamento. Em termos agregados, Moll (2014) mostra que choques na habilidade empresarial altamente persistentes geram perdas reduzidas na TFP no longo prazo em relação ao nível eficiente (sem restrições de crédito). Contudo, a transição (que pode ocorrer por uma reforma do crédito) tende a ser muito longa, gerando perdas elevadas na TFP. Isto ocorre uma vez que, se a habilidade é suficientemente persistente, o autofinanciamento é um substituto efetivo para o acesso ao crédito no longo prazo. Porém durante a transição, a alta persistência do choque na habilidade e o consequente autofinanciamento fazem com que a distribuição de habilidade e riqueza da população evolua lentamente para a distribuição estacionária de longo prazo. Isto gera uma transição lenta da TFP para seu nível de longo prazo.
} 
Tabela 4.1: Parâmetros do modelo.

\begin{tabular}{|c|c|c|}
\hline \multicolumn{3}{|c|}{ Parâmetros fixados } \\
\hline Parâmetros & Valores & Comentários \\
\hline $\mathrm{P}$ & 0,98 & Controla a persistência de $(e)$ \\
\hline $\mathrm{Y}$ & 2,0 & Aversão ao risco \\
\hline$\delta$ & 0,037 & Taxa de depreciação \\
\hline$(1-\alpha)(1-v)$ & 0,61 & Share da renda do trabalho \\
\hline \multicolumn{3}{|c|}{ Parâmetros calibrados conjuntamente } \\
\hline $\mathrm{v}$ & 0,20 & $\begin{array}{l}\text { Controla o share dos lucros } \\
\% \text { de empresários na população }(6,4)\end{array}$ \\
\hline$\beta$ & 0,92 & taxa de juros reais de 4\%a.a. \\
\hline$\sigma^{2}$ & 0,023 & $\%$ da renda dos $5 \%$ mais ricos $(33,7)$ \\
\hline$\lambda$ & 1,25 & (crédito para empresas)/PIB de 9,5\% \\
\hline $\mathrm{b}$ & 0,075 & (crédito ao consumidor)/PIB de 5,4\% \\
\hline
\end{tabular}

O "share" dos lucros foi calibrado em $v=0,20$. Ele foi utilizado para calibrar o percentual de empresários na população. Este é um valor muito utilizado na literatura (Buera e Shin, 2013).

A taxa de desconto foi calibrada em $\beta=0,92$ para reproduzir no modelo uma taxa de juros de $4 \%$ a.a.. Este valor é próximo da taxa de juros utilizada em Berriel e Zilberman (2011). A taxa de desconto está próxima dos valores estimados por Issler e Piqueira (2000) para o Brasil.

O parâmetro $\sigma^{2}$ foi calibrado para obter um percentual da renda dos $5 \%$ mais ricos de 33,7\%. Utilizamos este momento dado que temos uma maior concentração de empresários nesta faixa da população, tanto no modelo como nos dados. Não utilizamos o Gini dado que no modelo a renda do trabalho é a mesma para todos.

O parâmetro $\lambda$, que controla a restrição de crédito para as firmas no modelo, foi calibrado para reproduzir um crédito para as firmas como proporção do PIB de 9,5\%. O parâmetro $b$, que controla a restrição de crédito para os consumidores no modelo, foi calibrado para reproduzir um crédito ao consumidor como proporção do PIB de 5,4\%. A tabela 4.2 mostra o ajuste do modelo em relação à economia brasileira em 2001. 
Tabela 4.2: Ajuste do modelo.

\begin{tabular}{|l|c|c|}
\hline & $\begin{array}{c}\text { Economia brasileira } \\
2001\end{array}$ & Modelo base \\
\hline Taxa de juros reais (\%a.a.) & 4,0 & 3,7 \\
\hline \% de empresários na economia (\%) & 6,4 & 7,0 \\
\hline Crédito para empresas (\% do PIB) & 9,5 & 9,5 \\
\hline Crédito ao consumidor (\% do PIB) & 5,4 & 5,6 \\
\hline \% da renda dos 5\% mais ricos & 33,7 & 35,8 \\
\hline
\end{tabular}

Fontes: PNAD, 2001; BACEN.

A tabela 4.2 mostra que o modelo reproduz bem os momentos da economia brasileira em 2001.

\section{5}

\section{Exercícios realizados e resultados}

\subsection{1}

\section{Efeitos do aumento do crédito para as firmas}

Nesta subseção avaliaremos somente os efeitos macroeconômicos do aumento do crédito para as firmas. Na próxima subseção avaliaremos os efeitos conjuntos do crédito para as firmas e para o consumidor. Neste exercício simulamos no modelo o aumento ocorrido no crédito para as firmas de $10 \%$ do PIB em 2001 para cerca de 15\% do PIB em 2011. Para tanto calibramos a trajetória do parâmetro que controla a restrição de crédito para as firmas $(\lambda)$ de forma a reproduzir no modelo a trajetória de aumento do crédito para as empresas ocorrida no período. A partir disto, avaliamos os impactos sobre o PIB per capita e demais variáveis no modelo gerados por este aumento no crédito. 

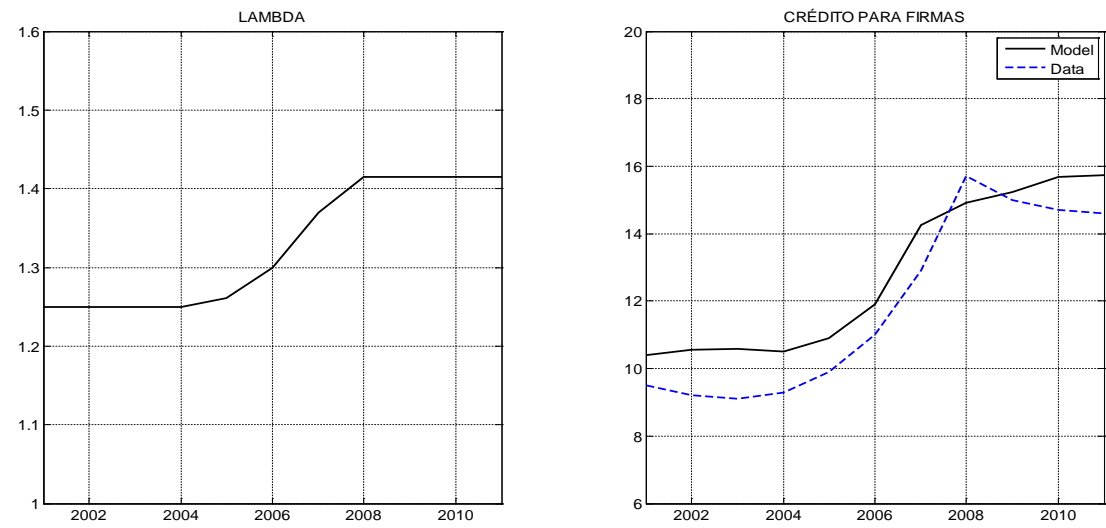

Figura 4.5: Elevação do crédito para as firmas: Trajetória do parâmetro que controla a restrição de crédito para as firmas (lambda), e trajetória do crédito (modelo e dados).

A figura 4.5 mostra a trajetória calibrada para o parâmetro $\lambda$ e o ajuste do modelo em relação aos dados da trajetória efetiva do crédito para as firmas. Neste caso, o modelo consegue reproduzir bem a trajetória do crédito no período. Os resultados para o PIB são expostos na figura 4.6:
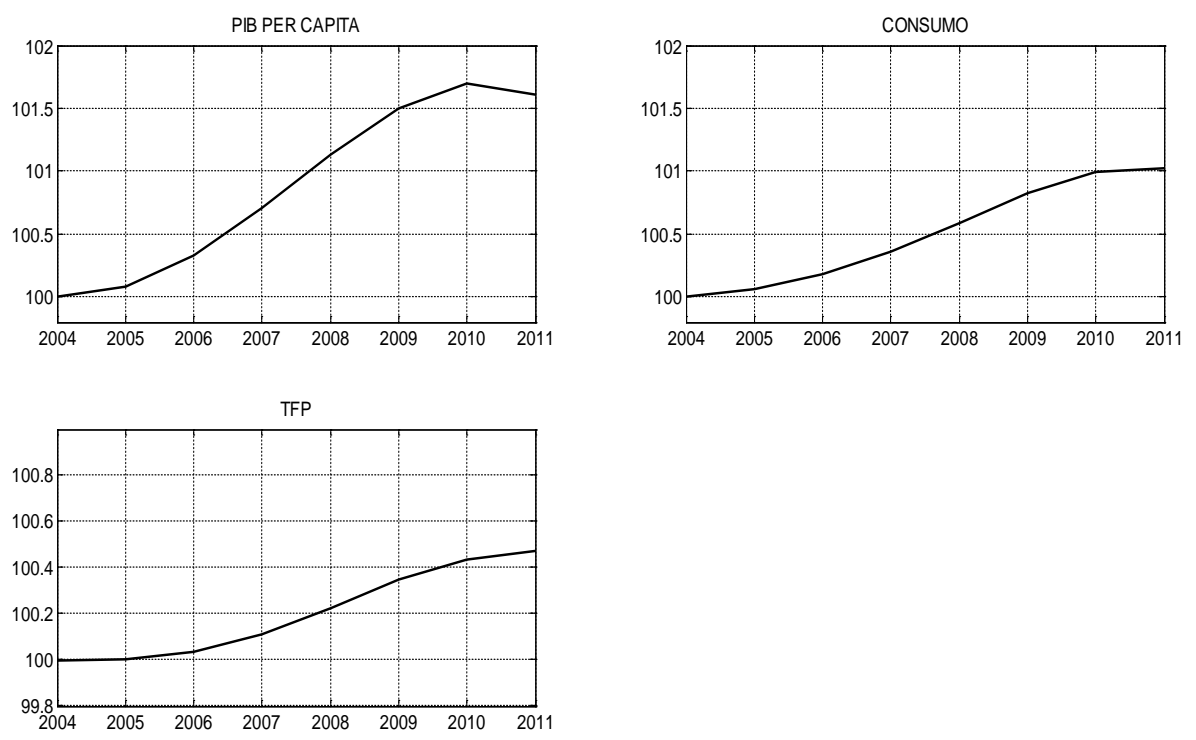

Figura 4.6: Elevação do crédito para as firmas: Efeitos sobre PIB per capita, consumo e TFP.

O aumento no crédito gerou um aumento de 1,5\% no PIB per capita no período. O consumo se eleva em $1 \%$ e a TFP aumenta cerca de $0,4 \%$. A figura 4.7 mostra os efeitos sobre as demais variáveis. 

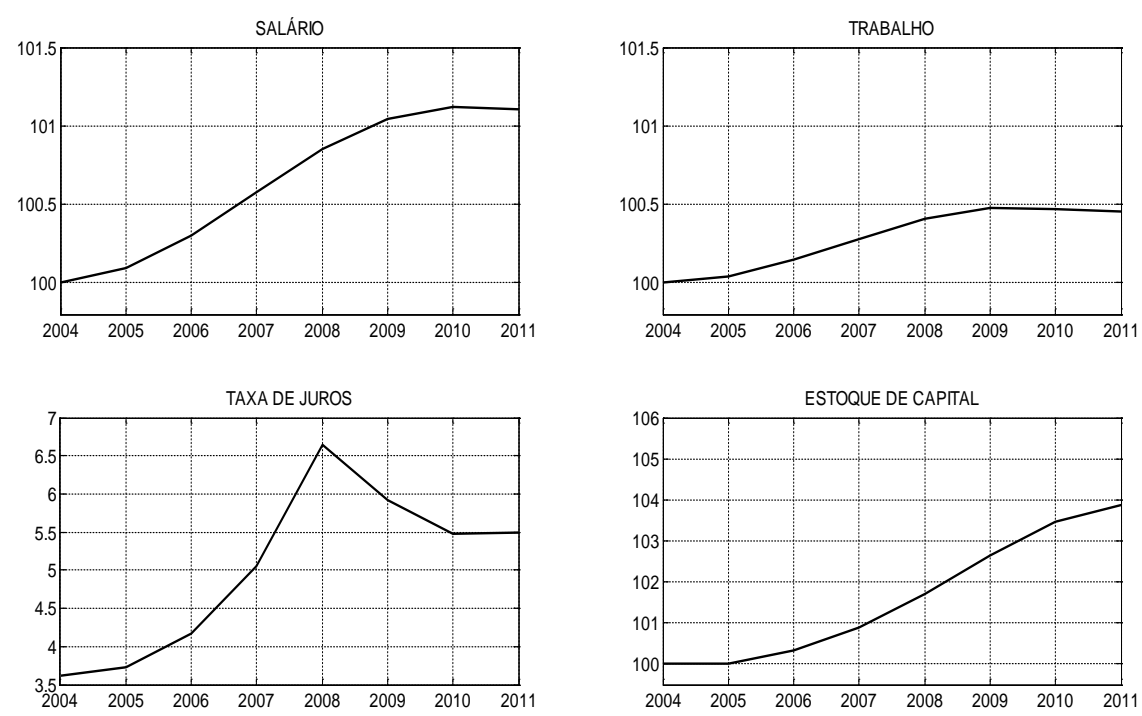

Figura 4.7: Elevação do crédito para as firmas: Efeitos sobre salários, quantidade de trabalho, taxa de juros e estoque de capital.

O salário se eleva um pouco acima de 1\%, o trabalho utilizado aumenta em $0,5 \%$ e o estoque de capital aumenta $4 \%$ no período.

Os efeitos descritos acima são gerados por um mecanismo no modelo que eleva a eficiência da economia. A restrição de crédito para as firmas impede que elas (ou a maioria delas) escolham o nível de capital que maximiza o lucro irrestrito. Dado que o capital contratado depende dos ativos da firma, teremos nesta economia firmas muito produtivas com ativos baixos que contratam pouco capital e firmas pouco produtivas com ativos elevados que contratam muito capital. Isto gera uma alocação ineficiente do capital e reduz a TFP. Quando se reduz a restrição de crédito, parte do capital flui das firmas menos produtivas para as mais produtivas o que eleva a TFP e o PIB. Este é o efeito na margem intensiva.

A restrição de crédito também impede que indivíduos com alta habilidade e ativos baixos se tornem empresários, pois eles não possuem colaterais suficientes para obter empréstimos e contratar o capital necessário. Isto gera uma alocação ineficiente do talento empresarial e reduz a TFP. O relaxamento da restrição de crédito permite que indivíduos de alta habilidade e ativos baixos se tornem empresários o que eleva a TFP e a renda. Este é o efeito na margem extensiva. 
A redução na restrição de crédito, mostrada na figura 4.5, permite que as firmas existentes elevem suas demandas por empréstimos para aumentar a quantidade de capital. Além disso, parte dos indivíduos mais produtivos com ativos baixos (que antes não podiam entrar no mercado) podem agora tomar empréstimos e entrar no mercado com firmas mais produtivas ${ }^{36}$. Assim a demanda agregada por empréstimos se eleva o que gera um aumento na taxa de juros e no estoque de capital, como mostrado na figura 4.7. A expansão do estoque de capital e da produção das firmas eleva a demanda por trabalho e a quantidade de trabalho utilizado (figura 4.7).

A redução na restrição de crédito permite que as firmas operem com um nível de capital e produção mais eficientes. Isto eleva a produtividade das firmas e consequentemente a TFP. A entrada de firmas mais produtivas com empresários mais habilidosos, eleva adicionalmente a TFP. A trajetória de aumento da TFP é mostrada na figura 4.6. O aumento da TFP, do estoque de capital e do trabalho geram a trajetória de crescimento do PIB per capita, que se eleva 1,5\% no período. O aumento da renda per capita eleva o consumo no período (figura 4.6). O aumento da produtividade do trabalho e da TFP elevam o salário.

Os dados mostram que entre 2004 e 2011 o PIB per capita cresceu 22,3\%. No modelo o aumento no crédito para as firmas gerou um aumento de 1,5\% no PIB per capita. Então o modelo explica cerca de 7\% do aumento do PIB per capita no período. Note que a maior parte da elevação do PIB per capita é explicada pela tendência de crescimento de longo prazo da economia e no modelo não consideramos esta tendência. Então supondo uma tendência de crescimento de $2 \%$ ao ano temos que o crescimento do PIB per capita não explicado pela tendência seria de 7,4\%. Neste contexto o modelo explica 20,3\% do crescimento do PIB não explicado pela tendência ${ }^{37}$.

\footnotetext{
${ }^{36}$ Note que neste modelo, quando um indivíduo com alta habilidade decide se tornar empresário, isto corresponde à entrada no mercado de uma firma com alta produtividade.

${ }^{37}$ Este resultado somente é válido com a hipótese forte de que o progresso técnico, que gera a tendência, não afeta o crédito de maneira significativa. Caso contrário, o resultado não é válido.
} 


\subsection{2}

\section{Efeitos do aumento do crédito para as firmas e para o consumidor}

Nesta subseção avaliaremos o efeito conjunto do aumento do crédito para as firmas e para o consumidor. Neste exercício simulamos no modelo o aumento ocorrido no crédito para as firmas de 10\% do PIB em 2001 para cerca de 15\% do PIB em 2011 em conjunto com o aumento ocorrido no crédito para o consumidor de cerca de 5\% para cerca de $15 \%$ do PIB. Para tanto calibramos a trajetória do parâmetro que controla a restrição de crédito para as firmas $(\lambda)$ de forma a reproduzir no modelo a trajetória de aumento do crédito para as empresas ocorrida no período. Além disso, calibramos a trajetória do parâmetro que controla a restrição de crédito para o consumidor (b) de forma a reproduzir no modelo a trajetória de elevação ocorrida no crédito para o consumidor. A partir disto, avaliamos os impactos sobre o PIB per capita e demais variáveis no modelo gerados por este aumento no crédito.
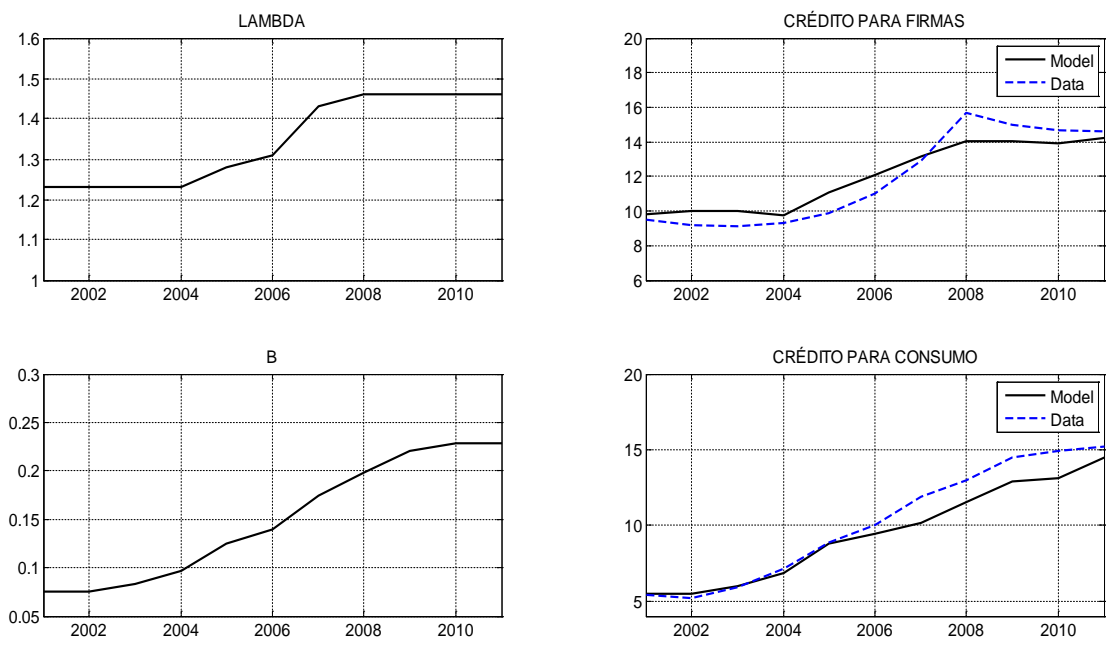

Figura 4.8: Elevação do crédito para firmas e consumidores: Trajetória dos parâmetros que controlam as restrições de crédito para as firmas (lambda) e para os consumidores (b), e trajetória do crédito para firmas e para consumo (modelo e dados).

Na figura 4.8, o painel superior esquerdo mostra a trajetória calibrada para o parâmetro $\lambda$ e o painel superior direito mostra o ajuste do modelo em relação aos dados da trajetória efetiva do crédito para as firmas. Neste caso, o modelo consegue reproduzir bem a trajetória do crédito para as firmas no período. O painel inferior esquerdo mostra a trajetória calibrada para o parâmetro $b$ e o painel 
inferior direito mostra o ajuste do modelo em relação aos dados. O modelo também reproduz bem a evolução do crédito ao consumidor. Os resultados para o PIB são expostos na figura 4.9:
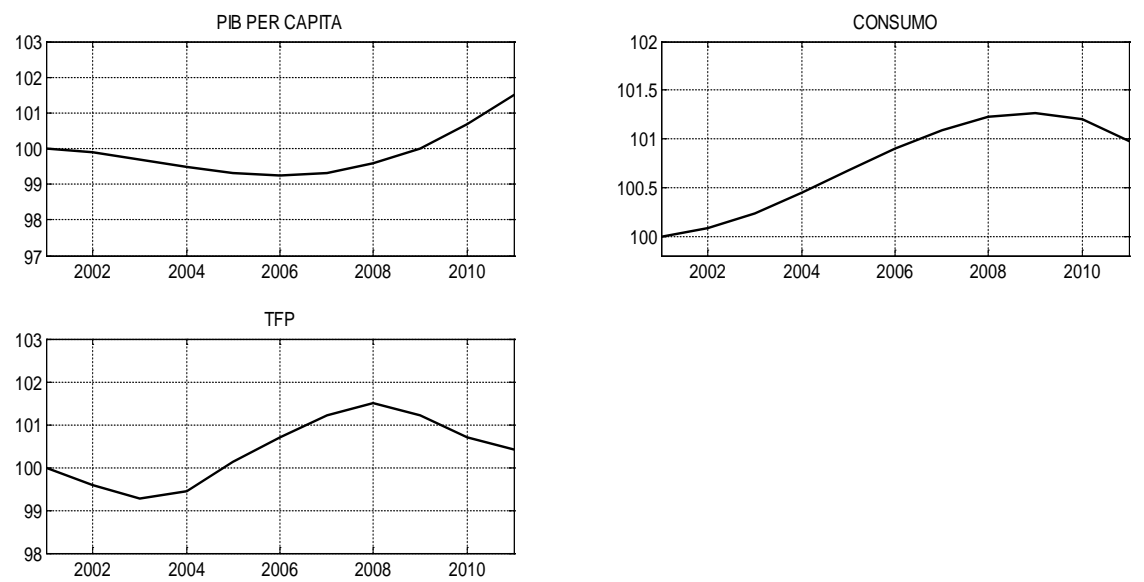

Figura 4.9: Elevação do crédito para firmas e consumidores: Efeitos sobre PIB per capita, consumo e TFP.

O PIB per capita se reduz levemente entre 2001 e 2006. Depois se eleva e atinge um crescimento de $1,5 \%$ no período. O consumo per capita se eleva $1 \%$ no período. A TFP se reduz levemente até 2004 e depois se eleva e atinge um crescimento de 0,4\%. A figura 4.10 apresenta as demais variáveis.
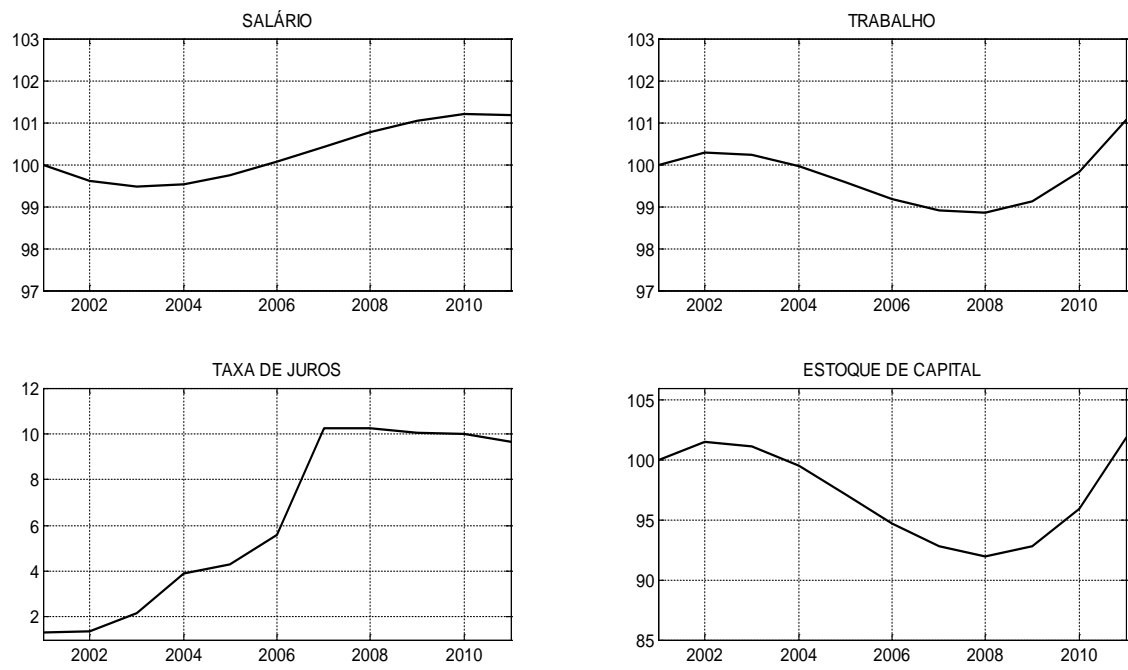

Figura 4.10: Elevação do crédito para firmas e consumidores: Efeitos sobre salários, quantidade de trabalho, taxa de juros e estoque de capital. 
O salário se eleva 1\% no período. O trabalho se eleva levemente entre 2001 e 2004, depois se reduz entre 2004 e 2008 e a partir deste ponto se eleva e termina o período com um aumento de 1\%. A taxa de juros se reduz em $2001 \mathrm{em}$ relação ao nível de estado estacionário inicial e se mantém constante até 2002. Entre 2002 e 2011 a taxa de juros se eleva fortemente. O estoque de capital se eleva levemente entre 2001 e 2004. Depois se reduz fortemente até 2008. A partir deste ano o estoque de capital volta a crescer e finaliza o período com um estoque praticamente constante em relação ao nível inicial em 2001.

Nesta economia os indivíduos possuem expectativas racionais, contudo o exercício é feito de tal forma que no início de 2001 os agentes são surpreendidos (depois não se surpreendem mais). Até o início de 2001 os agentes esperavam que a economia continuasse no estado estacionário inicial que manteria todas as variáveis constantes, ou crescendo a taxas constantes. No início de 2001 eles são surpreendidos e a partir deste momento passam a incorporar a informação da trajetória de elevação do crédito até 2011. Entre 2001 e 2004 o crédito para as firmas como proporção do PIB não se altera e o crédito para o consumidor se eleva muito pouco. Desta forma os efeitos sobre a economia até 2004 são gerados pela antecipação dos agentes do processo de elevação futura do crédito.

Neste contexto, a taxa de juros se reduz fortemente em 2001 em relação ao nível de estado estacionário inicial (próximo a 4\%). Isto ocorre porque agora os indivíduos esperam que as taxas de juros futuras se elevem e por isso aumentam suas poupanças o que eleva a oferta de crédito. Como a demanda de crédito ainda não se elevou, dado que as restrições de crédito, no início do período, são praticamente as mesmas, o resultado é uma redução na taxa de juros. Esta redução eleva o estoque de capital e consequentemente a quantidade de trabalho até 2004. O aumento do estoque de capital e de trabalho das firmas, que produzem com retornos decrescentes de escala, reduz a produtividade das mesmas e consequentemente reduz a TFP. Esta queda na TFP reduz levemente o PIB até 2004.

A partir de 2004 as restrições de crédito se reduzem fortemente, o que eleva a demanda por crédito. Este aumento na demanda eleva as taxas de juros. O aumento no crédito ao consumidor reduz a quantidade de recursos reais disponíveis para emprestar para as firmas. Esta redução nos recursos disponíveis 
para as firmas, em conjunto com o aumento das taxas de juros, gera uma redução no estoque de capital de equilíbrio e consequentemente no trabalho de equilíbrio.

Como descrito na subseção anterior, a redução na restrição de crédito ao produtor permite que as firmas operem com um nível de capital e produção mais eficientes. Isto eleva a produtividade das firmas e consequentemente a TFP a partir de 2004. A entrada de firmas mais produtivas com empresários mais habilidosos, eleva adicionalmente a TFP. A trajetória de aumento da TFP é mostrada na figura 9. Entre 2004 e 2008 o PIB permanece aproximadamente constante pois o aumento na TFP é compensado pela redução no estoque de capital e de trabalho. A partir de 2008 o PIB se eleva em função do aumento na TFP e da recuperação no estoque de capital e de trabalho. Os salários se elevam em função do aumento na TFP e o consumo cresce em função do aumento no crédito ao consumidor e do aumento na renda.

Devemos notar que o crédito ao consumidor e o crédito para as firmas possuem efeitos macroeconômicos bastante distintos. O aumento do crédito para as firmas eleva a TFP e o PIB per capita. Por outro lado, o aumento no crédito ao consumidor, basicamente, aumenta o consumo, eleva a taxa de juros e reduz o estoque de capital. Isto ocorre devido à competição entre consumidores e produtores pelo crédito disponível.

\section{6 \\ Conclusão}

Os resultados dos exercícios realizados mostram que a elevação no crédito entre 2001 e 2011 gerou impactos sobre a economia. O aumento do crédito para empresas gerou impactos pequenos sobre o PIB per capita e a TFP. O aumento do crédito para empresas de 5\% do PIB gerou um aumento de 1,5\% no PIB per capita.

Devemos notar que neste modelo, o PIB per capita é afetado, basicamente, pelo aumento do crédito para as empresas. Dado que o nível deste tipo de crédito no Brasil ainda é muito baixo em relação aos demais países (como proporção do PIB), existe ainda um grande espaço potencial para aumentos substanciais do crédito ao produtor, o que geraria aumentos expressivos no PIB per capita. 


\section{Restrições de crédito sobre as firmas, PIB per capita e o percentual de empresários no Brasil: o período 2004-2008}

\section{1 \\ Introdução}

No capítulo 3 mostramos que no período 2001-2011 ocorreu um forte aumento do crédito no Brasil. Neste período, o crédito com recursos livres dobrou, passando de 15\% do PIB para 30\% do PIB. O crédito para as firmas se elevou, passando de 10\% em 2001 para 15\% do PIB em 2011. Estes dados demostram o crescimento expressivo do crédito no período. A figura 5.1 mostra a evolução do crédito privado com recursos livres como proporção do PIB.

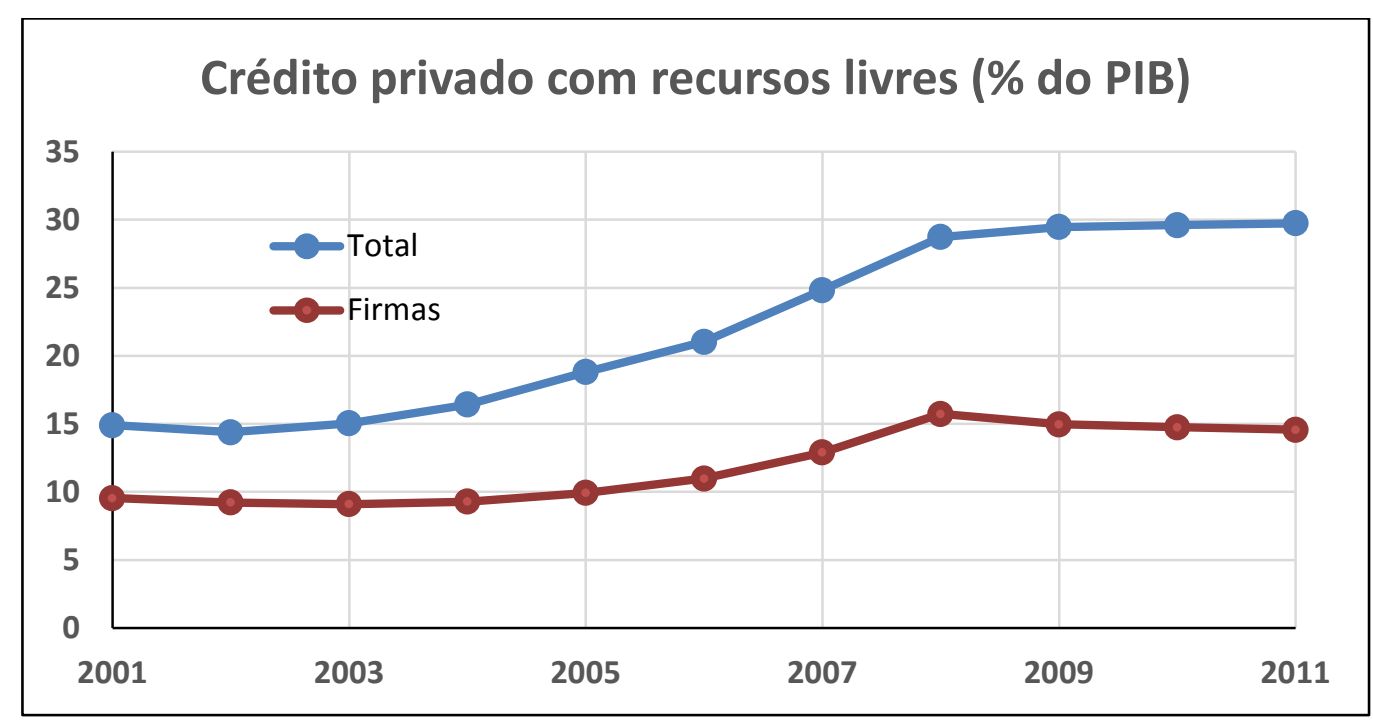

Figura 5.1: Crédito privado com recursos livres como proporção do PIB. Fonte: BACEN.

O crédito para as firmas corresponde aos recursos emprestados para as pessoas jurídicas do setor privado.

Devemos notar que o crédito para as firmas com recursos livres permaneceu praticamente constante entre 2001 e 2004. Além disso, este crédito permaneceu aproximadamente constante entre 2008 e 2011. Contudo, entre 2004 e 2008 o crédito para as empresas cresce fortemente passando de cerca de 10\% do 
PIB em 2004 para cerca de 15\% do PIB em 2008. Neste trabalho estaremos interessados no aumento do crédito para as firmas, com recursos livres, ocorrido entre 2004 e 2008. No capítulo 4 descrevemos os fatores que contribuíram para a elevação do crédito neste período.

Neste capítulo, nosso objetivo é avaliar o impacto do aumento do crédito no Brasil no período 2004-2008 sobre o PIB per capita, com a utilização do modelo de Lloyd-Ellis e Bernhardt (2000). Assim poderemos comparar os resultados desse modelo com os resultados do modelo utilizado no capítulo 4 . Além disso, avaliaremos os impactos do aumento do crédito sobre o percentual de empresários na economia. Para realizar nosso objetivo, utilizamos uma versão do modelo de Lloyd-Ellis e Bernhardt (2000) onde uma parte do modelo é estimada e o restante é calibrado para a economia brasileira. Neste capítulo, fazemos um exercício de simulação onde avaliamos os impactos do aumento do crédito com recursos livres ${ }^{38}$. A contribuição do trabalho para a literatura no Brasil é avaliar o impacto do crédito sobre o PIB per capita entre 2004-2008 com uma versão do modelo de crescimento que utiliza uma abordagem mista de calibração e estimação com o uso de microdados.

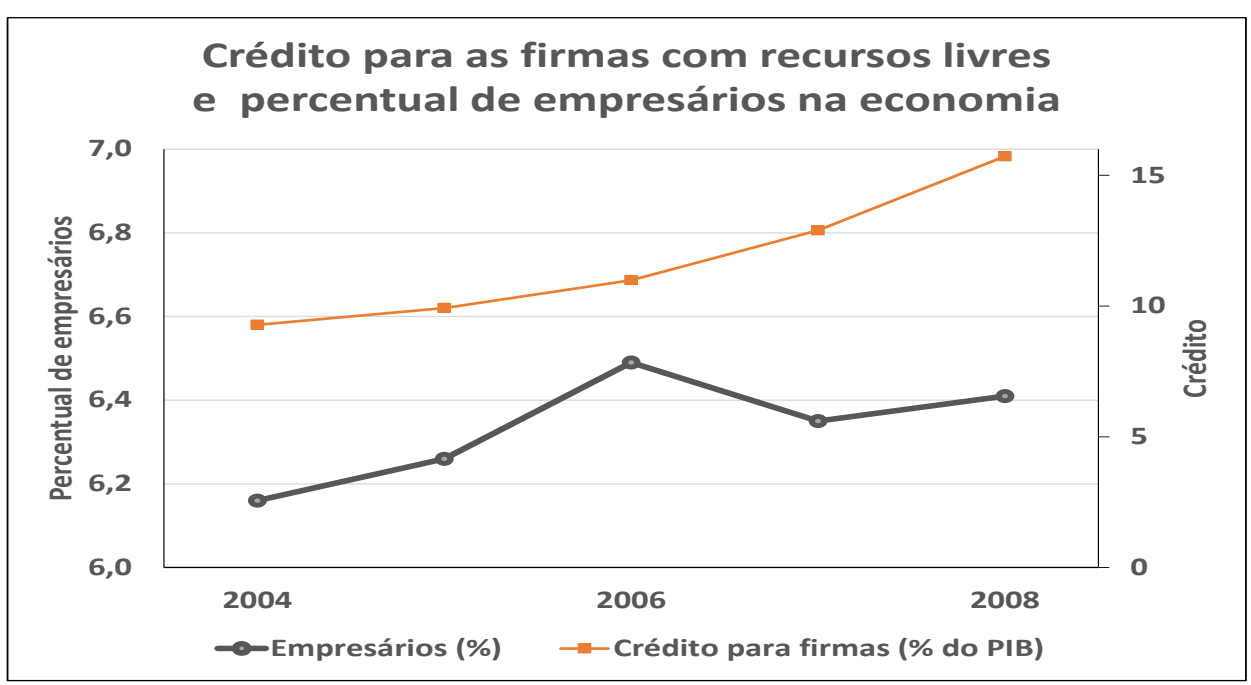

Figura 5.2: Crédito para as firmas com recursos livres e percentual de empresários na economia.

Fonte: BACEN e PNAD.

\footnotetext{
${ }^{38}$ Estes recursos são emprestados com taxas de juros livremente negociadas no mercado. Então não avaliaremos o impacto do crédito direcionado, que é obtido com taxas de juros subsidiadas. Isto significa, basicamente, que não avaliaremos os efeitos do crédito fornecido pelo Banco Nacional de Desenvolvimento Econômico e Social (BNDES). Para avaliar os efeitos do crédito subsidiado seria necessário modelar a economia com um agente que empresta com taxas de juros subsidiadas e se financia por meio de impostos. Como não era nosso objetivo fazer este tipo de análise neste trabalho resolvemos não avaliar o crédito subsidiado.
} 
A figura 5.2 mostra a evolução do crédito para as firmas com recursos livres e do percentual de empresários na economia. O percentual de empresários passou de aproximadamente 6,2\% em 2004 para cerca de 6,4\% em 2008, correspondendo a um aumento de 4,1\% na fração de empresários.

Nós utilizamos uma versão do modelo de Lloyd-Ellis e Bernhardt (2000). Neste caso, nosso modelo é uma versão do modelo de crescimento neoclássico com famílias heterogêneas e firmas heterogêneas. As famílias são heterogêneas na quantidade de ativos que possuem e no custo de instalação de uma firma (que mede o inverso da habilidade empresarial do indivíduo). O modelo inclui escolha ocupacional, neste caso, em cada período, os indivíduos escolhem entre trabalhar em troca de um salário ou atuar como um empresário. Existem dois regimes na economia, um com acesso ao crédito e outro sem acesso ao crédito. Uma parte da população vive no regime com crédito e a outra parte vive no regime sem crédito. O montante de capital que a firma pode contratar depende do valor dos ativos que ela possui. O modelo não possui incerteza agregada.

O modelo possui um mecanismo onde reduções nas restrições de crédito para as firmas elevam o percentual de empresários na economia, a TFP e o PIB per capita. A restrição de crédito para as firmas (em ambos os regimes) impede que elas (ou a maioria delas) escolham o nível de capital que maximiza o lucro irrestrito. Dado que o capital contratado depende dos ativos da firma, teremos nesta economia firmas muito produtivas, com ativos baixos, que contratam pouco capital e firmas pouco produtivas, com ativos elevados, que contratam muito capital. Isto gera uma alocação ineficiente do capital e reduz a TFP. Quando se eleva o percentual da população com acesso ao crédito, parte das firmas muito produtivas que viviam no regime sem crédito migra para o regime com crédito. Isto permite que elas contratem mais capital e elevem a produção em direção ao nível eficiente irrestrito, o que eleva a produtividade delas. No agregado, parte do capital flui das firmas menos produtivas para as mais produtivas, o que eleva a TFP e o PIB. Este é o efeito na margem intensiva.

A ausência de financiamento no regime sem acesso a crédito impede que indivíduos com alta habilidade e ativos baixos, residentes neste regime, se tornem empresários, pois eles não possuem riqueza suficiente para financiar o custo de instalação e contratar o capital necessário. Isto gera uma alocação ineficiente do talento empresarial e reduz a TFP. O aumento na população com acesso a crédito 
permite que parte dos indivíduos de alta habilidade e ativos baixos, que residiam no regime sem crédito, se tornem empresários no regime com crédito, o que eleva o percentual de empresários na população, a TFP e o PIB per capita. Este é o efeito na margem extensiva.

Na implementação do modelo, utilizamos uma abordagem mista de estimação e calibração. Os parâmetros tecnológicos foram estimados por máxima verossimilhança com o uso de microdados da PNAD. Os demais parâmetros do modelo foram calibrados. Uma parte dos parâmetros foi fixada levando em conta dados da economia brasileira. O restante dos parâmetros foi calibrado de forma a reproduzir, no modelo, momentos específicos da economia brasileira em 2004. Os momentos reproduzidos no modelo foram o percentual de empresários na economia, o crédito para as firmas como proporção do PIB e a taxa de poupança da economia. O modelo reproduz relativamente bem os dados para 2004 no Brasil.

Neste texto avaliamos os efeitos sobre a economia do aumento do crédito para as firmas. Este crédito aumentou cerca de 50\% no período. Nós modelamos este processo de forte aumento como uma elevação de $50 \%$ no percentual da população com acesso a crédito. Neste caso, modelamos o processo de expansão do crédito entre 2004 e 2008, sendo derivado de um aumento exógeno da população com acesso a crédito na economia.

Os resultados mostram que o aumento no crédito gerou um aumento expressivo do percentual de empresários no período. Entre 2004 e 2006, a elevação do crédito gerou um aumento de cerca de 5\% no percentual de empresários na economia. Para o período compreendido entre 2004 e 2008 o aumento no percentual de empresários foi de $9 \%$ no modelo. O aumento efetivo nos dados foi de 4,1\%. O modelo se ajusta muito bem aos dados entre 2004 e 2006. Para 2007 e 2008 o modelo não simula adequadamente o ocorrido nos dados.

O aumento do crédito elevou o PIB per capita em 2\% entre 2004 e 2008 no modelo. Este resultado é muito próximo do resultado obtido com o modelo utilizado no capítulo 4.

O restante do texto é organizado da seguinte forma: a seção 2 fornece uma breve revisão da literatura relacionada ao trabalho, a seção 3 descreve o modelo utilizado, a seção 4 apresenta a estimação/calibração do modelo, a seção 5 
descreve os resultados dos exercícios realizados e por fim, na seção 6 apresentamos as conclusões.

\section{2}

\section{Revisão da literatura}

Nosso trabalho está relacionado a uma literatura que utiliza versões do modelo de crescimento neoclássico com agentes heterogêneos e restrições de crédito exógenas para avaliar o impacto do crédito sobre a TFP e o PIB per capita (Buera e Shin, 2013 e Curtis,2016).

Este capítulo também está relacionado a uma literatura que utiliza versões do modelo de crescimento neoclássico com agentes heterogêneos, "enforcement” limitado e restrições de crédito endógenas (Antunes, Cavalcanti e Villamil, 2008, 2014; Buera, Kaboski e Shin, 2011).

Nosso trabalho está inserido em uma literatura que utiliza versões menos complexas do modelo de crescimento neoclássico com agentes heterogêneos e restrições de crédito. Estas versões menos complexas permitem utilizar modelos estruturais onde parte dos parâmetros são estimados (Jeong e Townsend,2008; Giné e Tonwsend,2004). Giné e Townsend (2004) avaliam os efeitos sobre o crescimento econômico e a distribuição da renda da liberalização financeira observada na Tailândia entre 1976 e 1996. Eles utilizam um modelo de equilíbrio geral menos complexo (o modelo de Lloyd-Ellis e Bernhardt,2000) e estimam parte dos parâmetros por máxima verossimilhança. Os resultados do trabalho mostram que a expansão do crédito foi fundamental para a trajetória de crescimento observada na Tailândia no período considerado.

Nosso trabalho também está relacionado a uma literatura sobre “misallocation” (Hsieh e Klenow, 2009; Midrigan e Xu, 2014), dado que na modelagem que utilizamos, o aumento da eficiência na alocação dos recursos é importante para explicar os efeitos do crédito sobre total de firmas, TFP e PIB.

No Brasil temos poucos trabalhos que utilizam versões do modelo de crescimento neoclássico com agentes heterogêneos e restrições de crédito (Antunes, Cavalcanti e Villamil, 2008, 2014). 
Neste capítulo utilizamos uma extensão do modelo de Lloyd-Ellis e Bernhardt (2000) com dois setores, um com acesso ao crédito e o outro sem acesso ao crédito. O modelo original de Lloyd-Ellis e Bernhardt (2000) possui apenas um setor com acesso ao crédito. Nesse sentido, nosso modelo é muito próximo de Giné e Townsend (2004). No modelo deles, o setor com acesso a financiamentos não possui imperfeições do mercado de crédito. No nosso modelo existe uma imperfeição no setor com acesso ao crédito, definida por um limite de endividamento para as firmas. Se este limite for suficientemente grande, nosso modelo é equivalente ao modelo de Giné e Townsend (2004). Além disso, avaliamos impactos sobre o percentual de empresários e não impactos distributivos e sobre o crescimento, como fazem Giné e Townsend (2004).

A contribuição do trabalho para a literatura no Brasil é avaliar o impacto do crédito sobre o percentual de empresários entre 2004-2008 com uma versão do modelo de crescimento que utiliza uma abordagem mista de calibração e estimação com o uso de microdados da PNAD.

\section{3}

\section{Modelo}

Nós utilizamos uma extensão do modelo de Lloyd-Ellis e Bernhardt (2000). Neste caso, nosso modelo é uma versão do modelo de crescimento neoclássico com famílias heterogêneas e firmas heterogêneas. As famílias são heterogêneas na quantidade de ativos que possuem e no custo de instalação de uma firma (que mede o inverso da habilidade empresarial do indivíduo). O modelo inclui escolha ocupacional, neste caso, em cada período, os indivíduos escolhem entre trabalhar em troca de um salário ou atuar como um empresário. Existem dois regimes na economia, um com acesso ao crédito e outro sem acesso ao crédito. Uma parte da população vive no regime com crédito e a outra parte vive no regime sem crédito. O montante de capital que a firma pode contratar depende do valor dos ativos que ela possui. O modelo não possui incerteza agregada.

A população da economia é formada por um contínuo de agentes de medida um e ela evolui ao longo do tempo discreto $t=0,1,2 \ldots$ Um agente com 
riqueza de final de período $\mathrm{W}_{\mathrm{t}}$ na data $\mathrm{t}$ maximiza a utilidade individual em relação ao consumo $c_{t}$ e a riqueza deixada como herança $b_{t+1}$. A função utilidade é dada por:

$$
U\left(c_{t}, b_{t+1}\right)=c_{t}^{1-\omega} b_{t+1}^{\omega}
$$

A restrição orçamentária é dada por:

$$
c_{t}+b_{t+1}=W_{t}
$$

Existem dois tipos de tecnologias de produção e um único bem. No setor tradicional, todos recebem um retorno seguro $\gamma$ da atividade de subsistência na produção deste bem. No setor moderno, os empresários contratam capital $k_{t} \mathrm{e}$ trabalho $l_{t}$ a cada data t para produzir o bem de acordo com a função de produção:

$$
f\left(k_{t}, l_{t}\right)=\alpha k_{t}-\frac{\beta}{2} k_{t}^{2}+\xi l_{t}-\frac{\rho}{2} l_{t}^{2}+\sigma_{t} k_{t}
$$

Esta função quadrática pode ser vista como uma aproximação para qualquer função de produção ${ }^{39}$ e tem sido utilizada em trabalhos aplicados ${ }^{40}$. Este tipo de função facilita a derivação de soluções de forma fechada e permite que o "share" do trabalho varie ao longo do tempo.

Cada trabalhador fornece uma unidade de trabalho e recebe o salário $w_{t}$ na data t. Existe um custo fixo de entrada para se tornar um empresário no setor moderno. Neste caso, ele paga um custo de instalação para iniciar uma firma. Este custo representa o inverso do talento empresarial de cada agente. Supomos que ele é independente do nível de riqueza $b_{t}$ e é retirado aleatoriamente de uma distribuição cumulativa invariante no tempo:

$$
H(x)=m x^{2}+(1-m) x
$$

O suporte de $x$ é o intervalo [0,1] e $m$ pertence ao intervalo [-1,1]. Se $m=0$ temos que a distribuição é uniforme. Conforme $m$ se aproxima de 1 , a distribuição de $x$ se torna mais assimétrica para direita e os empresários eficientes se tornam raros.

Neste modelo, um agente é definido por um par de características do início do período: a riqueza inicial $b_{t}$ e o custo de instalação $x_{t}$. Devido à forma funcional da função utilidade, as regras ótimas para o consumo e a poupança serão

\footnotetext{
${ }^{39}$ De fato, esta função pode ser vista como uma aproximação de Taylor de segunda ordem de uma função de produção arbitrária, quando as derivadas de terceira ordem são negligenciáveis.

${ }^{40}$ Vide Giné e Townsend (2004).
} 
funções lineares da riqueza. Neste caso, a maximização da utilidade é equivalente à maximização da riqueza de final de período.

Existe um nível de salário de reserva $\underline{w}=\gamma$ abaixo do qual cada trabalhador potencial prefere permanecer no setor de subsistência. Além disso, se o salário excede o nível de reserva, ninguém permanece no setor de subsistência. Portanto, o modelo implica que o salário deve ser $\underline{w}=\gamma$ quando o setor de subsistência coexiste com o setor moderno. Supomos que a renda de subsistência cresce a uma taxa exógena de $g_{\gamma}$. Quando os dois setores coexistem, a demanda de trabalho do setor moderno determina a proporção da população de trabalhadores assalariados e trabalhadores de subsistência.

Nesta economia existem dois regimes distintos, um com acesso a crédito e outro sem acesso a crédito. Uma parte da população vive no regime com acesso a crédito e a outra parte no regime sem intermediação financeira. Os dois regimes são descritos abaixo.

\subsection{1}

\section{Regime sem acesso a crédito}

Os indivíduos que vivem no regime sem acesso ao crédito precisam financiar o custo de instalação e o capital contratado com recursos próprios. Dado o salário de equilíbrio $w_{t}$, um agente do tipo $(b, x)$ escolhe sua ocupação para maximizar sua riqueza total $W^{\varsigma}$ :

$$
\begin{aligned}
W^{\mathcal{S}} & =\gamma+b, \text { para trabalhadores de subsistência } \\
& =w+b, \text { para trabalhadores assalariados } \\
& =\pi^{s}(b, x, w)+b, \text { para empresários, }
\end{aligned}
$$

onde $\pi^{s}(b, x, w)$ é o lucro do empresário e é dado por:

$$
\begin{gathered}
\pi^{s}(b, x, w)=\max _{k, l}\{f(k, l)-w l-k-x\} \\
\text { s.a. } 0 \leq k \leq b-x
\end{gathered}
$$

Quanto maior a riqueza inicial $b$, maior a probabilidade que um agente será um empresário. Um agente eficiente, $\operatorname{com} x$ baixo, não consegue se tornar um empresário se tiver uma riqueza inicial $b$ muito baixa. Dada a riqueza $b$ e o salário 
$w$, podemos definir um agente marginal como aquele que possui o custo de instalação $x^{m s}(b, w)$ que é indiferente entre ser um trabalhador e ser um empresário, tal que $\pi^{s}\left(b, x^{m s}, w\right)=w$. Se o custo de instalação do indivíduo é maior do que este nível crítico, ele será um trabalhador com certeza. Além disso, devido à restrição da demanda de capital, o custo de instalação não pode exceder a riqueza $b$ do indivíduo. Neste caso, dado o salário $w$, o custo de instalação crítico para o agente marginal com riqueza $b$, que está disposto a ser um empresário, é dado por:

$$
z^{s}(b, w)=\min \left\{b, x^{m s}(b, w)\right\}
$$

Em resumo, famílias de diferentes talentos estão submetidas a um mercado de crédito imperfeito (ou ausência deste mercado) no financiamento de novas firmas e na expansão da escala das firmas existentes. Dessa forma, as famílias são restritas pela riqueza limitada, em uma margem extensiva de escolha de ocupação e em uma margem intensiva de capital utilizado, embora estas restrições sejam aliviadas ao longo do tempo. Conforme a distribuição de riqueza evolui, também evolui a composição ocupacional da população (em termos de trabalhadores e empresários) e os diferenciais de rendimentos, gerando a dinâmica de crescimento na economia.

As escolhas ótimas dos indivíduos, dadas as suas características, determinam uma partição do espaço de escolha ocupacional $(b, x)$ em três regiões: firmas irrestritas, firmas restritas e trabalhadores (assalariados ou de subsistência).

\subsubsection{1}

\section{A partição do espaço $(b, x)$ segundo a ocupação no regime sem crédito}

Para um indivíduo com riqueza de início do período $b$, dado um salário de equilíbrio $w$, temos dois níveis críticos de custo de instalação: $\mathrm{z}(b, w)$ e $x^{u}(b, w)$. Se o custo de instalação do indivíduo $x$ for maior do que $\mathrm{z}(b, w)$ ele será um trabalhador, caso contrário, ele será um empresário. Além disso, se $0 x$ do indivíduo for menor do que $x^{u}(b, w)$ ele será um empresário irrestrito.

A seguir descreveremos como as curvas $\mathrm{z}(b, w)$ e $x^{u}(b, w)$ são obtidas. Do problema de maximização de lucro da firma obtemos as demandas ótimas de 
capital e trabalho. A escolha ótima de trabalho $l$ dado o capital ótimo $k^{S}(b, x, w)$ é dada por $^{41}$ :

$$
l^{s}(b, x, w)=\frac{\sigma k^{s}(b, x, w)+(\xi-w)}{\rho}
$$

Suprimindo o argumento $(b, x)$, o lucro (antes da dedução do custo de instalação) e a demanda por trabalho podem ser expressas como funções do capital $k$, dado o salário $w^{42}$ :

$$
\begin{aligned}
& \pi^{s}(k, w)=f\left(k, l^{s}(k, w)\right)-w l^{s}(k, w)-k \\
& =k\left(\alpha-1+\frac{\sigma}{\rho}(\xi-w)\right)+\frac{k^{2}}{2}\left(\frac{\sigma^{2}}{\rho}-\beta\right)+\frac{(\xi-w)^{2}}{2 \rho}
\end{aligned}
$$

Note que a expressão acima é quadrática em $k$.

Definimos $x^{*}$ como o custo de instalação máximo, tal que para todo $x>x^{*}$ o indivíduo nunca será um empresário. Em termos formais $x{ }^{*}$ é tal que:

$$
x^{*}=\pi^{u}-w \text {, onde } \pi^{u}=\max _{k} \pi(k, w)
$$

Neste caso, se $x>x^{*}$, a renda máxima que um empresário pode obter será sempre menor do que $w$ e assim o indivíduo estará sempre melhor se escolher ser um trabalhador.

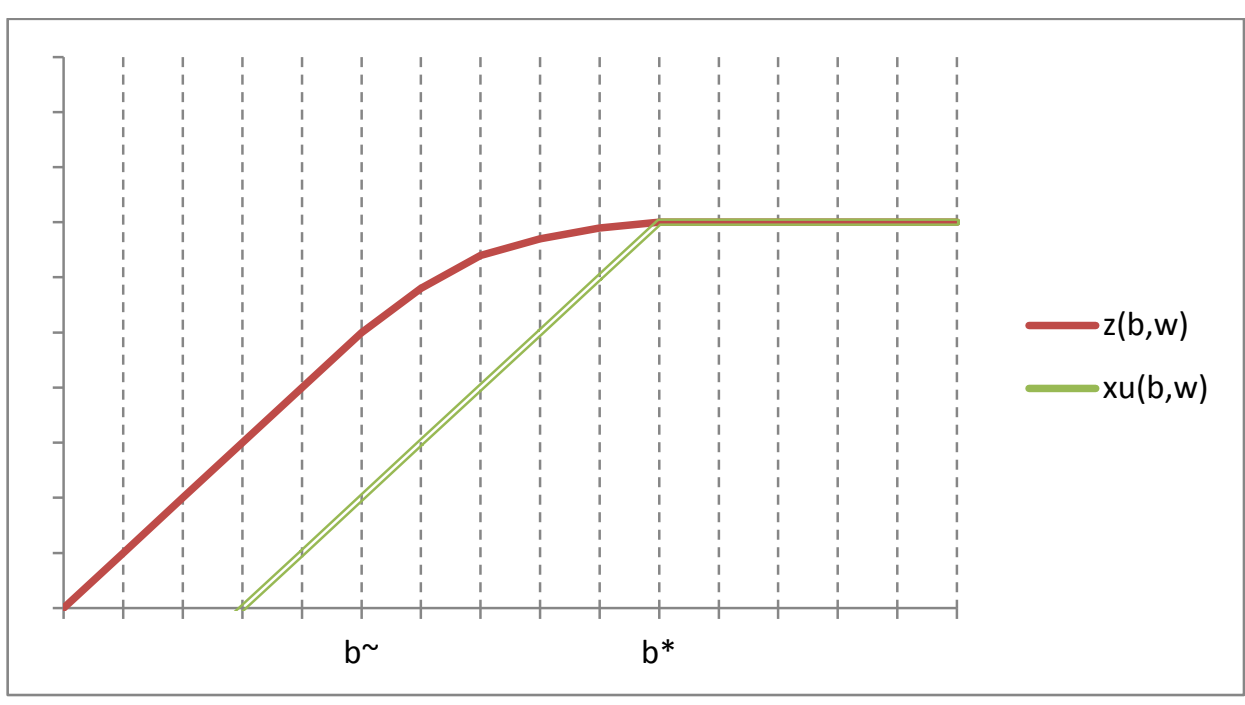

Figura 5.3: Mapa de escolha ocupacional.

\footnotetext{
${ }^{41}$ Vide Anexo D.

42 Vide Anexo D.
} 
Definimos como $b^{*}$ o nível de riqueza mínimo de um empresário com custo $x^{*}$ tal que ele é irrestrito:

$$
b^{*}=x^{*}+k^{u}, \text { onde } k^{u}=\arg \max _{k} \pi(k, w)
$$

Por definição, $b^{*}$ é tal que para toda riqueza $b>b^{*}$ e $x<x^{*}$, a família é uma firma e é irrestrita. Como $z(b, w)$ determina o ponto de indiferença entre ser um trabalhador ou empresário, temos que $z(b, w)=x^{*}$ para $b \geq b^{*}$. Além disso, dado que $x^{u}(b, w)$ é a curva que separa empresários restritos e irrestritos, $x^{u}(b, w)=x^{*}$ para $b \geq b^{*}$ e neste caso as duas curvas são iguais (vide figura 5.3).

No caso de $b<b^{*}$, o agente sempre será restrito como uma firma no ponto de indiferença ocupacional $z(b, w)$ entre se tornar um trabalhador ou empresário. Neste caso, podemos usar a demanda de capital restrita $k^{c}=b-\chi$ para determinar $z(b, w)$, levando em conta que $z(b, w) \leq b$, dado que o empresário deve ter riqueza suficiente para financiar o custo de instalação.

Por definição, o ponto de indiferença na ocupação $z(b, w)$ é obtido quando o lucro, líquido do custo de instalação, é igual ao salário:

$$
w=\pi^{s}\left(k^{c}, w\right)-x, \quad k^{c}=b-x
$$

Esta é uma expressão quadrática em $x$ que, dado $\mathrm{b}<\mathrm{b}^{*}$, determina o nível de $x$ que faz um agente indiferente entre ser um trabalhador ou empresário. Devemos notar que $x$ não pode ser maior do que $b$. Definimos $\tilde{b}$ tal que $z(\tilde{b}, w)=\tilde{b}$. Então para $b<\tilde{b}$ temos $z(b, w)=b$.

\section{3 .2}

\section{Regime com acesso a crédito}

Os indivíduos que vivem neste setor podem depositar suas riquezas de início de período no intermediário financeiro e receber a taxa de juros bruta $R$. Se o indivíduo decide se tornar um empresário, ele pode tomar emprestado a uma taxa de juros de $R$ para financiar seu custo de instalação e o investimento em capital. Existe um limite máximo de endividamento para contratar capital. Este limite é definido como um percentual dos ativos do indivíduo. Supomos que a taxa de juros é a mesma para todos no setor intermediado. 
Dado o salário de equilíbrio $w_{t}$, um agente do tipo $(b, x)$ escolhe sua ocupação para maximizar sua riqueza total $W^{c}$ :

$W^{c}=\gamma+R . b$, para trabalhadores de subsistência

$=w+R \cdot b$, para trabalhadores assalariados

$=\pi^{c}(b, x, w)+R \cdot b$, para empresários

onde $\pi^{c}(b, x, w)$ é o lucro do empresário (líquido do custo de instalação) e é dado por:

$$
\begin{gathered}
\pi^{c}(b, x, w)=\max _{k, l}\{f(k, l)-w l-R k-R x\} \\
\text { s.a. } 0 \leq k \leq \lambda b
\end{gathered}
$$

Neste caso, o máximo de capital que um empresário pode contratar é um percentual " $\lambda$ " do valor do seu colateral $b$. Este parâmetro $\lambda$ mede o grau de imperfeição no mercado de crédito para as firmas. Esta especificação está de acordo com o resultado dos modelos com contratos com “enforcement” limitado onde o montante de crédito é limitado pela riqueza financeira do empresário. Esta especificação tem sido usada extensamente na literatura sobre fricções financeiras e escolha ocupacional ${ }^{43}$.

Dada a riqueza $b$ e o salário $w$, também podemos definir um agente marginal neste regime como aquele que possui o custo de instalação $x^{m c}(b, w)$ que é indiferente entre ser um trabalhador e ser um empresário, tal que $\pi^{c}\left(b, x^{m c}, w\right)=w$. Se o custo de instalação do indivíduo é maior do que este nível crítico, ele será um trabalhador com certeza. Neste setor o custo de instalação é financiado pelo intermediário financeiro e neste caso pode exceder a riqueza $b$ do indivíduo. Dado o salário $w$, o custo de instalação crítico para o agente marginal com riqueza $b$, que está disposto a ser um empresário, é dado por:

$$
z^{c}(b, w)=x^{m c}(b, w)
$$

No regime de crédito, as escolhas ótimas dos indivíduos também determinam uma partição do espaço de escolha ocupacional $(b, x)$ em três regiões: firmas irrestritas, firmas restritas e trabalhadores (assalariados ou de subsistência). Estas regiões são diferentes das regiões determinadas no regime sem crédito, devido à possibilidade de tomar empréstimos.

\footnotetext{
${ }^{43}$ Vide Buera, Kaboski e Shin (2011) e Buera e Shin (2013).
} 


\subsection{3}

\section{Equilíbrio competitivo}

Definimos $G_{t}(b)$ como a distribuição de heranças (riqueza) no tempo t. Integrando as decisões ótimas dos agentes ao longo dos seus tipos $(b, x)$ para cada regime, obtemos o total de empresários do setor com acesso a crédito $E_{t}^{c}\left(w_{t}\right)$ e o total do setor sem acesso ao crédito $E_{t}^{s}\left(w_{t}\right)$. O total de empresários na população é dado pela soma dos empresários nos dois setores ponderada pelo percentual da população em cada setor:

$$
E_{t}\left(w_{t}\right)=(1-\delta) E_{t}^{s}\left(w_{t}\right)+\delta E_{t}^{c}\left(w_{t}\right)=(1-\delta) \int H\left(z^{s}\left(b, w_{t}\right)\right) G_{t}(d b)+\delta \int H\left(z^{c}\left(b, w_{t}\right)\right) G_{t}(d b)
$$

Onde $\delta$ é o percentual da população que vive no setor com acesso a crédito.

O custo de instalação médio $X_{t}^{c}\left(w_{t}\right)$, no setor com acesso a crédito, é dado por:

$$
X_{t}^{c}\left(w_{t}\right)=\iint_{0}^{z^{c}\left(b, w_{t}\right)} x H(d x) G_{t}(d b)
$$

A demanda agregada de trabalho é dada por:

$$
\begin{aligned}
& L_{t}\left(w_{t}\right)=(1-\delta) L_{t}^{s}\left(w_{t}\right)+\delta L_{t}^{c}\left(w_{t}\right)=(1-\delta) \iint_{0}^{z^{s}\left(b, w_{t}\right)} l^{s}\left(b, x, w_{t}\right) H(d x) G_{t}(d b)+ \\
& \delta \iint_{0}^{z^{c}\left(b, w_{t}\right)} l^{c}\left(b, x, w_{t}\right) H(d x) G_{t}(d b)
\end{aligned}
$$

Onde o sobrescrito $s$ é referente ao agregado no setor sem crédito e o sobrescrito $c$ é referente ao agregado no setor com crédito.

A demanda agregada de capital, no setor com acesso a crédito, é dada por:

$$
K_{t}^{c}\left(w_{t}\right)=\iint_{0}^{c^{c}\left(b, w_{t}\right)} k^{c}\left(b, x, w_{t}\right) H(d x) G_{t}(d b)
$$

O total de trabalhadores de subsistência é dado por:

$$
S_{t}\left(w_{t}\right)=1-E_{t}\left(w_{t}\right)-L_{t}\left(w_{t}\right)
$$

Estes agregados são funções no tempo do salário uma vez que eles dependem da distribuição da riqueza herdada.

Um equilíbrio competitivo para esta economia com distribuição de heranças $G_{t}(b)$ consiste de sequências $\left\{w_{t}^{e}, R_{t}^{e}, E_{t}^{e}, L_{t}^{e}, S_{t}^{e}\right\}$ tais que:

Dado o salário $w_{t}^{e}$ e a taxa de juros bruta $R_{t}^{e}$, um agente do tipo $(b, x)$ seleciona sua ocupação para maximizar a utilidade no regime em que vive (com acesso a crédito ou sem acesso a crédito). 
O empresário do tipo $(b, x)$ escolhe a demanda de capital e a demanda de trabalho para maximizar os lucros sujeito à restrição de crédito no regime em que vive (com ou sem intermediação).

O mercado de capital, no setor com acesso a crédito, se equilibra para todo t:

$$
\iint_{0}^{z^{c}\left(b, w_{t}\right)} k^{c}\left(b, x, w_{t}\right) H(d x) G_{t}(d b)=\iint b^{c} H(d x) G_{t}(d b)-X_{t}^{c}\left(w_{t}\right)
$$

O lado esquerdo da equação acima representa a demanda agregada de capital e o lado direito representa a oferta agregada de capital, líquida do custo de instalação. A condição de equilíbrio de mercado para a população total é satisfeita:

$$
\begin{aligned}
& E_{t}^{e}\left(w_{t}^{e}\right)+L_{t}^{e}\left(w_{t}^{e}\right)+S_{t}^{e}\left(w_{t}^{e}\right)=1 \\
& \text { onde } S_{t}^{e}\left(w_{t}^{e}\right)=0 \text { se } w_{t}^{e}>w
\end{aligned}
$$

A distribuição de riqueza evolui de acordo com uma função de transição de probabilidade não estacionária endógena $P\left(b^{\prime} \mid b, w_{t}\right)$, tal que a distribuição de heranças incondicional satisfaz:

$$
G_{t+1}\left(b^{\prime}\right)=\int P\left(b^{\prime} \mid b, w_{t}\right) G_{t}(d b)
$$

\section{4}

\section{Estimação/calibração do modelo}

A implementação deste modelo é realizada por meio da estimação de parte dos parâmetros e pela calibração dos demais. Os parâmetros da função de produção e o parâmetro $m$, que determina a assimetria da distribuição do custo de instalação, são estimados por máxima verossimilhança. Os parâmetros restantes são calibrados. 


\subsection{1}

\section{Estimação com microdados}

\subsubsection{1}

\section{Base de dados}

Para estimar os parâmetros tecnológicos e $m$ construímos uma base de dados ao nível do indivíduo com informações sobre ocupação (se é empresário ou não) e nível de riqueza. Para tanto, utilizamos os microdados da PNAD em 2004 e 2005. O indivíduo foi definido como o chefe da família. Consideramos como empresários somente os chefes de família classificados como empregadores na PNAD.

Devemos lembrar que não temos informações sobre a riqueza ao nível dos indivíduos no Brasil. Neste caso, construímos um índice de riqueza utilizando características do domicílio do chefe da família que estão associadas à riqueza do indivíduo (como material das paredes, número de cômodos, etc). Para elaborar este índice utilizamos a abordagem dos fatores principais. A metodologia utilizada para construir o índice está baseada em Assunção e Alves,2007 e é descrita no Anexo C.

\subsubsection{2}

\section{Estimação}

Nós montamos a função de verossimilhança da escolha ocupacional e estimamos os parâmetros pela maximização da verossimilhança dos microdados. Definimos $y_{i}$ como uma variável binária de escolha ocupacional do agente $i$, onde $y_{i}=1$ se ele é um empresário e $y_{i}=0$ caso contrário. Dado o salário $w$, a probabilidade do agente $i$, com riqueza $b_{i}$, ser um empresário, é dada por:

$$
P\left\{y_{i}=1\right\}=P\left(x_{i} \leq z\left(b_{i} \mid \theta, w\right)\right)=H\left(z\left(b_{i} \mid \theta, w\right), m\right)
$$

onde: $\theta=(\beta, \alpha, \rho, \sigma, \xi)$

Temos que $z$ é a função custo de instalação crítico. Na equação acima explicitamos que ela depende dos parâmetros tecnológicos. Utilizando os dados 
“cross-section” de $n$ famílias sobre escolha ocupacional e riqueza $\left(y_{i}, b_{i}\right)_{i=1}^{n}$, o log da função de verossimilhança é dado por:

$$
\log L=\sum_{i=1}^{n}\left\{y_{i} \ln \left(H\left(z\left(b_{i} \mid \theta, w\right), m\right)\right)+\left(1-y_{i}\right) \ln \left(1-H\left(z\left(b_{i} \mid \theta, w\right), m\right)\right)\right\}
$$

A função custo de instalação crítico $z\left(b_{i} \mid \theta, w\right)$ é determinada pela função lucro ótimo e neste caso, depende dos parâmetros da função de produção $\theta=(\beta, \alpha, \rho, \sigma, \xi)$.

Não podemos usar diretamente a verossimilhança acima para estimar os parâmetros uma vez que somente três dos cinco parâmetros tecnológicos são identificados ${ }^{44}$. No Anexo D mostramos que a forma reduzida da função lucro é um polinômio do segundo grau no capital:

$$
\pi(b, x, w)=C_{0}(w)+C_{1}(w) k+C_{2} k^{2}-x
$$

onde: $C_{0}(w)=\frac{(\xi-w)^{2}}{2 \rho}, C_{1}(w)=\alpha-1+\frac{\sigma(\xi-w)}{\rho}, C_{2}=\frac{1}{2}\left(\frac{\sigma^{2}}{\rho}-\beta\right)$

Na equação acima o lucro depende somente de três parâmetros: $C_{0}, C_{1}$ e $C_{2}$. Como o custo de instalação crítico é função do lucro, ele também somente depende dos três parâmetros. Temos que $C_{0}, C_{1}$ e $C_{2}$ dependem dos parâmetros tecnológicos. Além disso, $C_{0}$ e $C_{1}$ são funções do salário $w$. Neste caso, somente três dos cinco parâmetros tecnológicos são identificados. Devido a isto, no Anexo D mostramos que:

$$
\log L(\alpha, \beta, \xi, \rho, \sigma, m ; w)=\log L\left(C_{0}, C_{1}, C_{2}, m ; w\right)
$$

Neste caso, a verossimilhança com os parâmetros tecnológicos é equivalente à verossimilhança com os parâmetros $C_{0}, C_{1}$ e $C_{2}$.

Para identificar todos os parâmetros tecnológicos utilizamos variação do salário $w$ entre dois períodos iniciais (2004 e 2005). Dessa forma, o log da verossimilhança, que utilizamos para estimar os parâmetros, é dado por:

$\log L\left(C_{0}^{2004}, C_{1}^{2004}, C_{2}, m ; w^{2004}\right)+\log L\left(C_{0}^{2005}, C_{1}^{2005}, C_{2}, m ; w^{2005}\right)$

onde: $C_{0}^{2004}=C_{0}\left(w^{2004}\right), C_{1}^{2004}=C_{1}\left(w^{2004}\right), C_{0}^{2005}=C_{0}\left(w^{2005}\right), C_{1}^{2005}=C_{1}\left(w^{2005}\right)$,

Nós estimamos os parâmetros por máxima verossimilhança utilizando a equação acima. Os resultados são apresentados na tabela 5.1.

\footnotetext{
${ }^{44}$ No Anexo D tratamos deste problema de identificação de forma detalhada.
} 
Tabela 5.1: Parâmetros estimados.

\begin{tabular}{|c|c|c|c|c|c|}
\hline \multicolumn{5}{|c|}{ Parâmetros estimados } \\
\hline$\alpha$ & $\beta$ & $\xi$ & $\rho$ & $\sigma$ & $m$ \\
\hline 1,0844 & 0,0503 & 0,0753 & 0,0030 & 0,0009 & $-0,8$ \\
\hline
\end{tabular}

Os parâmetros são estimados utilizando a função custo de instalação crítico $z$ do setor sem acesso ao crédito. A estimação é realizada condicional ao parâmetro de escala $s$ que converte a riqueza nos dados (em $\mathrm{R} \$$ ) em unidades de riqueza do modelo. A escolha da escala é importante uma vez que o custo de instalação está limitado ao intervalo [0,1] e entra na equação do lucro de modo aditivo. $\mathrm{O}$ fator de escala $s$ foi calibrado no valor de $3,83 * 10^{-6}$.

\section{4 .2}

\section{Calibração}

Os valores calibrados dos parâmetros do modelo são apresentados na tabela 2. O parâmetro de escala $s$ foi fixado de tal forma que o salário médio de equilíbrio, no modelo em 2004 (em unidades monetárias do modelo), corresponde ao salário médio na economia observado em 2004 (em R\$). A renda de subsistência $\gamma$ é calibrada em 0,0441 para reproduzir o salário médio inicial em 2004, dada a escala do modelo. Neste caso, estamos supondo que o salário de subsistência é próximo do salário médio da economia em 2004. Supomos que o salário de subsistência cresce a uma taxa exógena $g_{\gamma}$ de $0,5 \%$ ao ano.

Os parâmetros $\delta$ (percentual da população com acesso a crédito), $\lambda$ (que determina a restrição de endividamento) e $\omega$ (taxa de herança) são calibrados conjuntamente de forma a reproduzir no modelo três momentos da economia brasileira em 2004: o percentual de empresários na população, o crédito para empresas como proporção do PIB e a taxa de poupança da economia. Embora os parâmetros sejam calibrados conjuntamente, cada parâmetro específico está mais diretamente relacionado a um momento específico. O percentual da população que vive no regime de crédito $\delta$ foi calibrado para obter um percentual de empresários na população de 6,2\%. O parâmetro $\lambda$ foi calibrado em 2,4 para reproduzir um crédito para empresas como proporção do PIB de 9,3\%. A taxa de herança $\omega$ foi calibrada para reproduzir uma taxa de poupança de 18\% do PIB. 
Tabela 5.2: Parâmetros calibrados.

\begin{tabular}{|l|l|l|}
\hline \multicolumn{2}{|l|}{ Parâmetros fixados } \\
\hline Parâmetros & Valores & Comentários \\
\hline$s$ & $3,83^{\star} 10^{-6}$ & Fator de escala \\
\hline$V$ & 0,0441 & Salário de subsistência \\
\hline$g_{Y}$ & 0,005 & Taxa de crescimento de $V$ \\
\hline Parâmetros calibrados conjuntamente \\
\hline$\delta$ & 0,40 & \% de empresários na população $(6,2)$ \\
\hline$\lambda$ & 2,4 & Crédito para empresas/PIB de 9,3\% \\
\hline$\omega$ & 0,18 & Taxa de poupança de 18\% do PIB \\
\hline
\end{tabular}

A tabela 5.3 mostra o ajuste do modelo em relação à economia brasileira em 2004.

Tabela 5.3: Ajuste do modelo.

\begin{tabular}{|c|c|c|}
\hline & $\begin{array}{c}\text { Economia brasileira } \\
\text { em } 2004\end{array}$ & Modelo base \\
\hline $\begin{array}{l}\text { \% de empresários na economia } \\
(\%)\end{array}$ & 6,2 & 8,8 \\
\hline Crédito para empresas (\% do PIB) & 9,3 & 7,3 \\
\hline Taxa de poupança & 18,0 & 18,0 \\
\hline
\end{tabular}

Fontes: PNAD; BACEN e Contas Nacionais-IBGE.

A tabela 5.3 mostra que o modelo reproduz bem os momentos da economia brasileira em 2004. A exceção é o percentual de empresários na economia que o modelo não reproduz muito bem.

\section{5}

\section{Exercícios realizados e resultados}

Nesta seção avaliaremos os efeitos macroeconômicos do aumento do crédito para as firmas. Este crédito aumentou cerca de 50\% no período. Nós modelamos este processo de forte aumento como uma elevação de 50\% no percentual da população com acesso a crédito. Neste caso, modelamos o processo de expansão do crédito entre 2004 e 2008, sendo derivado de um aumento exógeno da população com acesso a crédito. 
No modelo, o exercício consiste em elevar o parâmetro exógeno que determina o percentual da população com acesso a crédito $\delta$ de 0,4 em 2004 para 0,6 em 2008. Para tanto, a cada ano, a partir de 2005, elevamos o parâmetro $\delta$ em 0,05 até atingir 0,6 em 2008. Os impactos desta trajetória exógena de aumento da população com acesso a crédito são apresentados na figura abaixo.
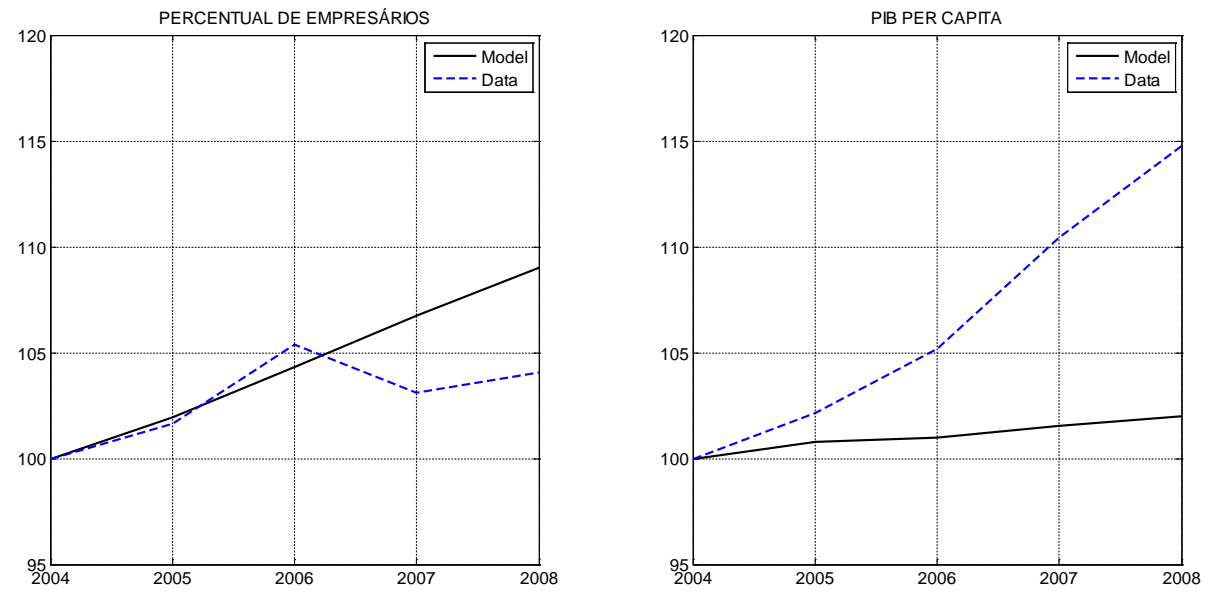

Figura 5.4: Aumento do percentual da população com acesso a crédito: Efeitos sobre o percentual de empresários e sobre o PIB per capita.

O aumento na população com acesso a crédito gerou um aumento de $9 \%$ no percentual de empresários no modelo. O aumento efetivo nos dados foi de 4,1\%. Devemos notar que o modelo se ajusta muito bem aos dados entre 2004 e 2006. Para 2007 e 2008 o modelo não simula muito bem o ocorrido nos dados sobre empresários.

O aumento no acesso ao crédito elevou o PIB per capita em 2\% entre 2004 e 2008 no modelo. Neste caso o modelo explica cerca de 13,5\% da elevação do PIB per capita no período. Devemos lembrar que a expansão do crédito é a única fonte de aumento do PIB per capita no modelo.

Os efeitos descritos acima sobre o percentual de empresários e o PIB per capita são gerados por um mecanismo no modelo que eleva a eficiência da economia. A restrição de crédito para as firmas (em ambos os regimes) impede que elas (ou a maioria delas) escolham o nível de capital que maximiza o lucro irrestrito. Dado que o capital contratado depende dos ativos da firma, teremos nesta economia firmas muito produtivas, com ativos baixos, que contratam pouco capital e firmas pouco produtivas, com ativos elevados, que contratam muito 
capital. Isto gera uma alocação ineficiente do capital e reduz a TFP. Quando se eleva o percentual da população com acesso ao crédito, parte das firmas muito produtivas que viviam no regime sem crédito migra para o regime com crédito. Isto permite que elas contratem mais capital e elevem a produção em direção ao nível eficiente irrestrito, o que eleva a produtividade delas. No agregado, parte do capital flui das firmas menos produtivas para as mais produtivas, o que eleva a TFP e o PIB. Este é o efeito na margem intensiva.

A ausência de financiamento, no regime sem acesso a crédito, impede que indivíduos com alta habilidade e ativos baixos, residentes neste regime, se tornem empresários, pois eles não possuem riqueza suficiente para financiar o custo de instalação e contratar o capital necessário. Isto gera uma alocação ineficiente do talento empresarial e reduz a TFP. O aumento na população com acesso a crédito permite que parte dos indivíduos de alta habilidade e ativos baixos, que residiam no regime sem crédito, se tornem empresários no regime com crédito, o que eleva o percentual de empresários na população, a TFP e o PIB. Este é o efeito na margem extensiva.

\section{5 .1}

\section{Efeitos sobre o PIB per capita com calibrações alternativas}

No exercício anterior, os efeitos sobre o PIB per capita foram obtidos considerando os parâmetros estimados e calibrados para 2004. Nesta subseção estimamos parte dos parâmetros e calibramos o modelo também para os anos de 2005 e 2006. Assim podemos verificar se os resultados da simulação se mantém com o modelo calibrado para outros anos. Os resultados são apresentados na figura abaixo: 


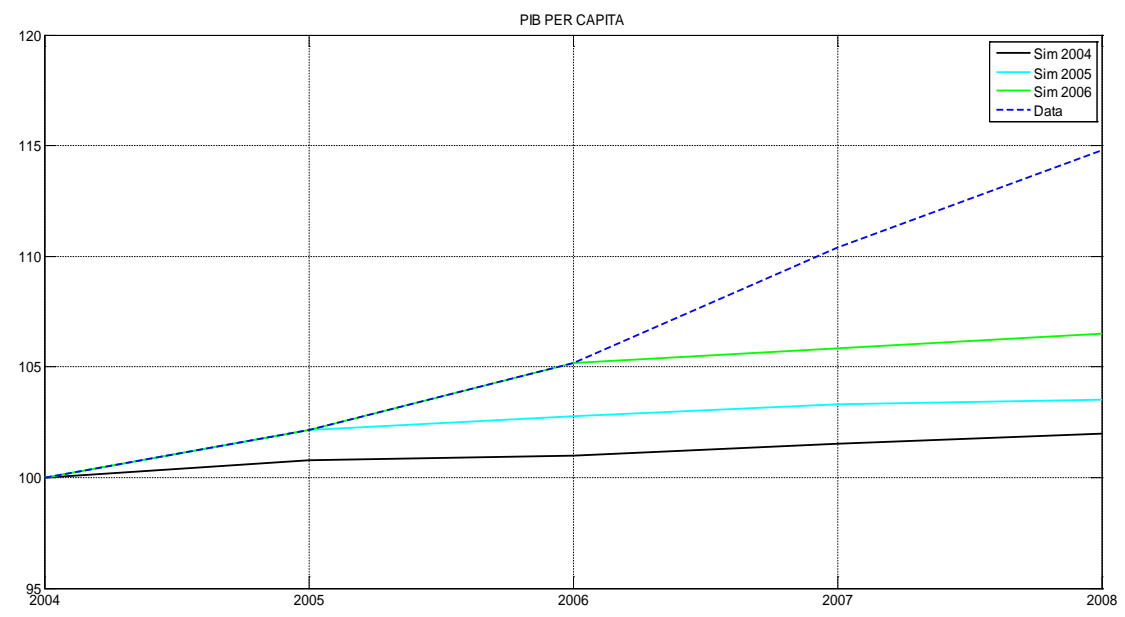

Figura 5.5: Aumento do percentual da população com acesso a crédito: Efeitos sobre o PIB per capita, com calibrações para 2004, 2005 e 2006.

Na figura 5.5, a curva sim 2004 representa a simulação realizada com o modelo calibrado para o ano de 2004. Além disso, as curvas sim 2005 e sim 2006 representam as simulações calibradas para 2005 e 2006 respectivamente. Nas três simulações supomos o mesmo aumento linear no crédito entre 2004 e 2008. As simulações mostram o mesmo efeito aproximado do crédito sobre o PIB per capita. Neste caso, estimar e calibrar o modelo para 2004, 2005 ou 2006 não afeta significativamente os resultados. Na figura abaixo apresentamos o resultado de cada simulação separadamente.
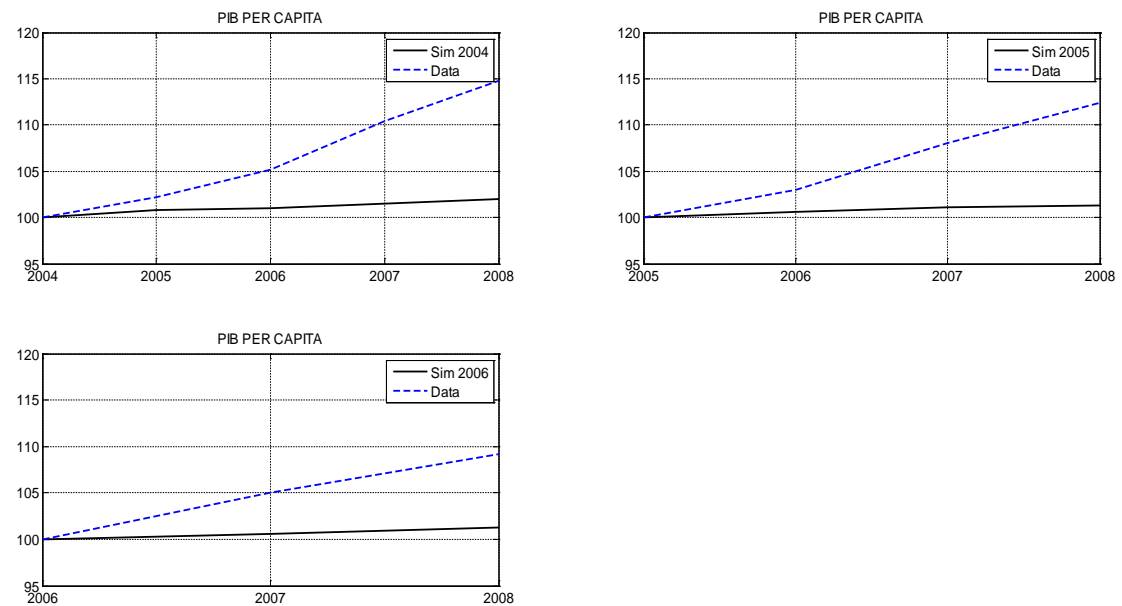

Figura 5.6: Aumento do percentual da população com acesso a crédito: Efeitos sobre o PIB per capita com calibrações para 2004, 2005 e 2006. 


\section{5 .2}

\section{Efeitos sobre as condições de escolha ocupacional}

Nesta subseção analisamos as alterações nas condições de escolha ocupacional geradas pela expansão do crédito entre 2004 e 2008. A figura abaixo apresenta o mapa de escolha ocupacional para 2004 e para 2008.
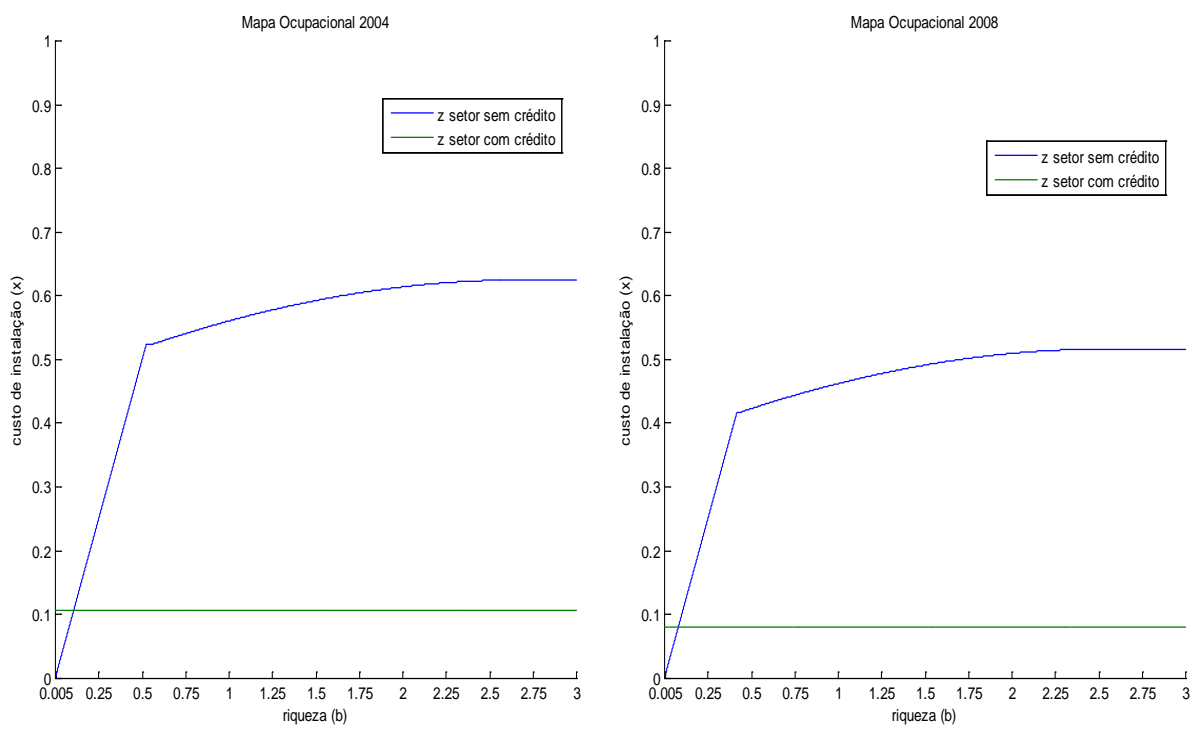

Figura 5.7: Mapas de escolha ocupacional para 2004 e para 2008.

A curva azul (tracejada) mostra o custo de instalação crítico z para os indivíduos que residem no setor sem acesso ao crédito. Nesse caso, dada a riqueza, os indivíduos com custo de instalação menor ou igual a z são empresários. Os demais são trabalhadores. A reta verde (contínua) mostra o custo de instalação crítico z para os residentes no setor com acesso ao crédito. Neste caso, os indivíduos com custo de instalação menor ou igual a 0,11 são empresários, independente da riqueza. Os demais são trabalhadores. A comparação entre os mapas de escolha ocupacional de 2004 e 2008 mostra que a região dos tipos de indivíduos (b,x) que são empresários se reduziu de 2004 para 2008. Isto ocorreu tanto no setor com crédito quanto no setor sem crédito. Essa mudança no mapa ocupacional é explicada principalmente pelo maior salário em 2008 em relação a 2004 (0,0441 em 2004 e 0,0462 em 2008). Este aumento no salário elevou o custo dos empresários e deixou a atividade empresarial menos 
atrativa para certos tipos de indivíduos (b,x). Note que os indivíduos que permanecem no regime sem crédito não são beneficiados pela expansão do acesso ao crédito. Os parâmetros tecnológicos estimados para 2008 estão muito próximos dos estimados para 2004. Neste caso, o mapa ocupacional praticamente não foi alterado por mudanças tecnológicas entre 2004 e 2008. A tabela abaixo mostra os parâmetros estimados para 2004 e 2008.

Tabela 5.4: Parâmetros estimados.

\begin{tabular}{|l|c|c|c|c|c|c|}
\hline \multicolumn{7}{|c|}{ Parâmetros estimados } \\
\hline & $\alpha$ & $\beta$ & $\xi$ & $\rho$ & $\sigma$ & $m$ \\
\hline 2004 & 1,0844 & 0,0503 & 0,0753 & 0,0030 & 0,0009 & $-0,8$ \\
\hline 2008 & 1,0839 & 0,0503 & 0,0731 & 0,0028 & 0,0009 & $-0,8$ \\
\hline
\end{tabular}

A figura a seguir divide o espaço (b,x) em quatro regiões. A região $(\mathrm{W}, \mathrm{W})$ (branca superior) representa os tipos de indivíduos $(b, x)$ que são trabalhadores se residem no regime com crédito ou no regime sem crédito. A região (E,W) (laranja escuro) representa os tipos de agentes que são empresários no setor sem crédito e são trabalhadores se residem no setor com crédito. A região (E,E) (branca inferior) mostra os indivíduos que são empresários em qualquer regime. Por fim, a região (W,E) (triângulo azul) mostra os tipos de indivíduos que são trabalhadores se residem no setor sem crédito e são empresários se residem no setor com crédito.
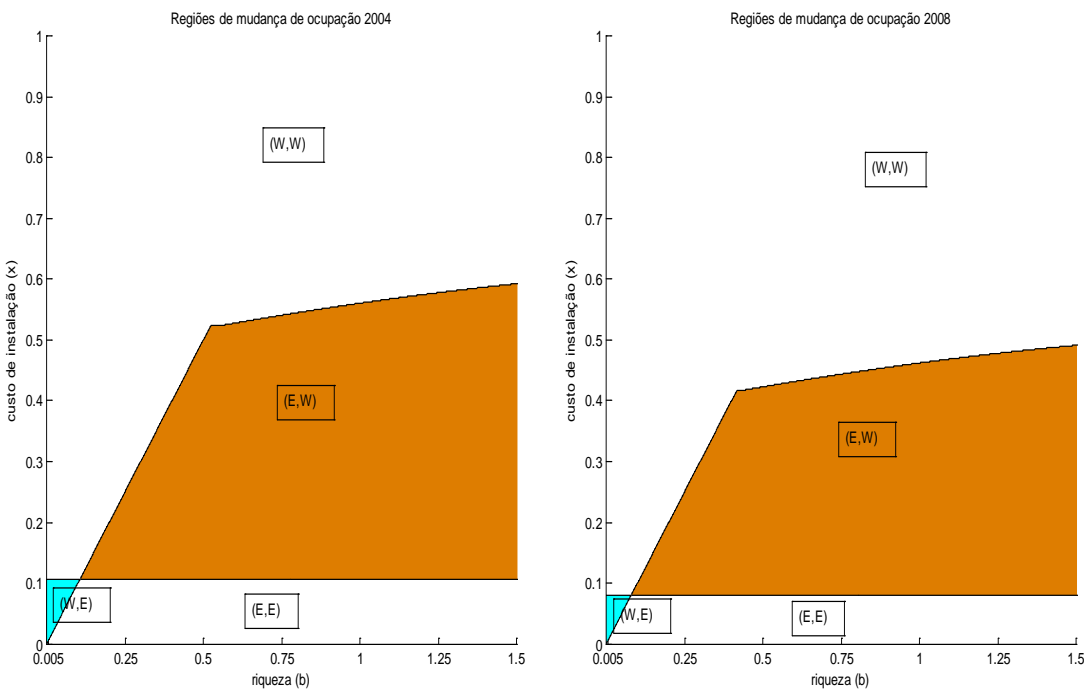

Figura 5.8: Regiões de mudança de ocupação em 2004 e 2008. 
Note que a região (W,E) se reduz entre 2004 e 2008. Esta região é formada por indivíduos altamente produtivos (com x baixo) mas que são trabalhadores se residem no setor sem crédito dado que possuem riqueza muito baixa. A figura abaixo mostra a probabilidade de um indivíduo ser empresário dada a sua riqueza. A curva azul mostra esta probabilidade para 2004 e a curva verde apresenta a probabilidade para 2008.
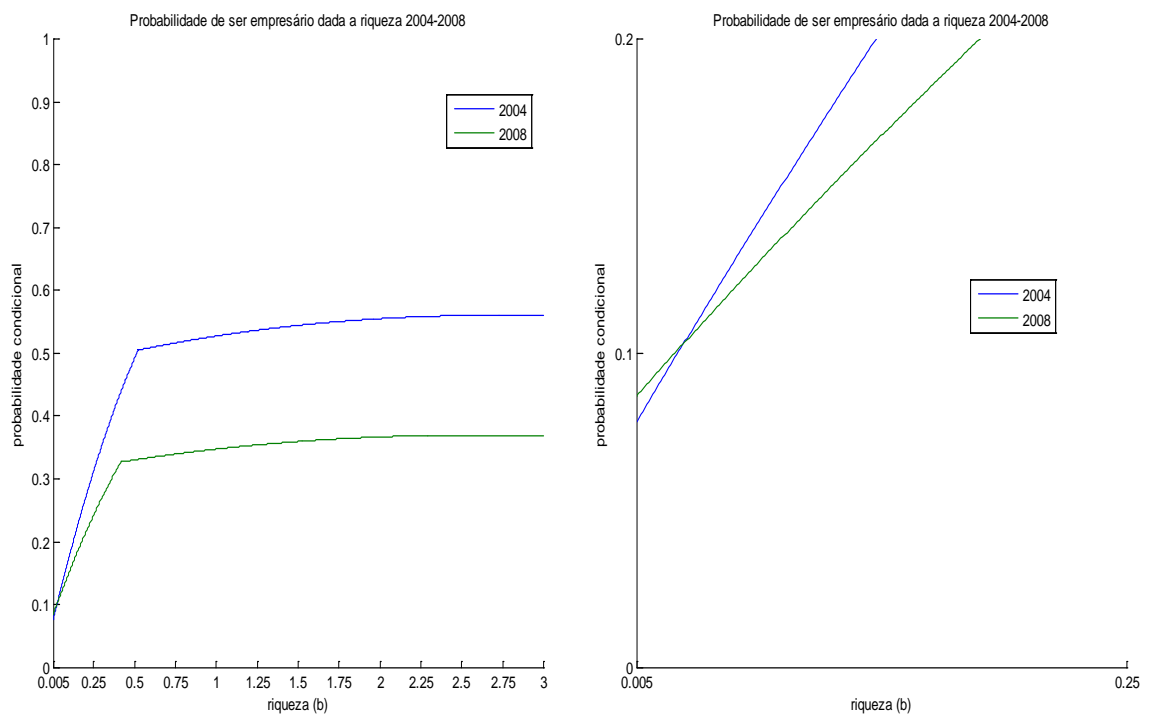

Figura 5.9: Probabilidade de ser empresário dada a riqueza em 2004 e 2008.

A figura 5.9 mostra que a probabilidade de ser empresário é maior em 2004 do que em 2008 para os indivíduos que possuem riqueza maior que 0,028. Por outro lado, a probabilidade de ser empresário é maior em 2008 em relação a 2004 para indivíduos com riqueza menor ou igual a 0,028. O gráfico da esquerda mostra a probabilidade para um intervalo de riqueza entre 0,005 e 3,00. O gráfico da direita é uma ampliação do primeiro gráfico no intervalo de riqueza entre 0,005 e 0 ,25. Isto permite uma melhor visualização do que ocorre nos menores níveis de riqueza.

Devemos notar que o percentual de empresários na população depende desta probabilidade de ser empresário dada a riqueza, mas também depende do percentual da população em cada nível de riqueza e do percentual da população que vive no regime com acesso a crédito. A população nesta economia é muito concentrada nos menores níveis de riqueza, onde mais de $80 \%$ da população 
possui riqueza inferior a 0,25 . As mudanças relevantes no mapa ocupacional se concentram na faixa de riqueza até 0,50.

\section{6}

\section{Conclusão}

O aumento no crédito para as empresas, entre 2004 e 2008, gerou um aumento significativo no percentual de empresários na economia. Entre 2004 e 2006 o percentual de empresários se elevou em 5\%.

O aumento no crédito para firmas gerou um aumento de $2 \%$ no PIB per capita entre 2004 e 2008. Desse modo, a expansão do crédito explica cerca de 13,5\% da expansão do PIB per capita no período. Estes resultados não se alteram significativamente mesmo estimando e calibrando o modelo para outros anos. Note que o aumento no PIB per capita é muito próximo do resultado obtido com o modelo utilizado no capítulo 3.

A expansão do crédito entre 2004 e 2008 também gerou alterações significativas nas condições de escolha ocupacional entre ser empresário ou trabalhador. 


\section{Conclusão}

Neste trabalho buscamos avaliar os impactos de aumentos no grau de desenvolvimento do sistema financeiro sobre a renda per capita no Brasil. Neste sentido, avaliamos o impacto de reduções nas imperfeições no mercado financeiro (reduções no custo de obtenção de informações sobre as firmas, aumentos no limite de endividamento das firmas e redução nos custos de transação no mercado de crédito) que elevam o desenvolvimento financeiro (aumento no acesso a serviços financeiros, elevação do aprofundamento financeiro e aumento da eficiência na intermediação) e desse modo, aumentam a renda per capita do país.

No capítulo 2 vimos que a redução do custo de participação no mercado de crédito (que eleva o acesso financeiro para o nível dos países desenvolvidos) gera um aumento no PIB per capita de 3,6\%. Além disso, a redução do custo de monitoramento (que eleva a eficiência do sistema para o nível dos países desenvolvidos) gera uma elevação no PIB per capita de 1,7\%. Por último vimos que a redução dos colaterais no Brasil, para o nível dos países desenvolvidos, elevaria o PIB per capita em $12 \%$.

Desse modo, neste trabalho, a restrição financeira com maior impacto sobre o PIB per capita, no caso brasileiro, é o limite de endividamento. Neste sentido, políticas voltadas para a redução das exigências de colaterais e aumento do grau de "enforcement” dos contratos, terão um impacto maior sobre o PIB do que políticas que visem reduzir o spread ou elevar a participação no mercado de crédito. Isto ocorre devido ao fato de que os empresários no Brasil são fortemente restritos por requerimentos de colaterais elevados. Assim uma redução no custo de intermediação somente beneficia um pequeno número de empresários que possuem colaterais suficientes para obter empréstimos.

Vimos que se o grau de aprofundamento financeiro no Brasil fosse igual à média dos países desenvolvidos, a renda per capita seria $12 \%$ maior. Para isto ocorrer, o crédito para as firmas teria que ser elevado de 10\% do PIB para cerca de $45 \%$ do PIB. Então teria que ocorrer um aumento enorme do crédito para as firmas para que a renda per capita se elevasse em $12 \%$. 
No capítulo 3, o aumento no crédito com recursos livres para as firmas de 10\%, em 2001, para 15\% do PIB em 2011, gerou um aumento de 1,5\% no PIB per capita no período. Devemos notar que este pequeno impacto do crédito sobre o PIB per capita está de acordo com o resultado obtido no capítulo 2 com relação ao aprofundamento financeiro.

No período 2001-2011 o aprofundamento do crédito para as firmas foi obtido, em grande parte, pelas alterações na legislação que fortaleceram os direitos dos credores. Em particular, as alterações na Lei de Falências permitiram reduzir o risco do credor e elevar o grau de "enforcement" dos contratos. Para elevar ainda mais o grau de aprofundamento de crédito na economia brasileira é necessário continuar aprimorando a legislação para fortalecer ainda mais os direitos do credor.

Em resumo, este trabalho mostra que o grau de desenvolvimento financeiro é importante para explicar o nível de renda per capita no Brasil. Neste sentido, se o grau de aprofundamento financeiro no Brasil se elevasse para o nível dos países desenvolvidos, o PIB per capita se elevaria em 12\%. Além disso, se o nível de acesso financeiro no Brasil fosse igual ao nível dos países desenvolvidos, a renda per capita seria 3,6\% maior. Por último, se o grau de eficiência do sistema financeiro brasileiro fosse o mesmo dos países de renda elevada, a renda per capita seria $1,7 \%$ maior.

Este trabalho também mostra que o aprofundamento financeiro ocorrido no Brasil entre 2001 e 2011 gerou um pequeno aumento de 1,5\% na renda per capita. Isto ocorreu devido ao pequeno aumento no crédito para as firmas (de 5\% do PIB) no período, em relação ao que seria necessário para atingir o nível de aprofundamento dos países desenvolvidos (um aumento de 35\% do PIB). 


\section{Referências bibliográficas}

ACEMOGLU, D.. Introduction to modern economic growth. Princeton University Press, Princeton, 2009.

AFONSO, J.; KOHLER, M.; FREITAS, P.. Evolução e determinantes do spread bancário no Brasil. Texto para discussão 61, Centro de Estudos da Consultoria do Senado Federal, 2009.

AIYAGARI, S.. Uninsured idiosyncratic risk and aggregate saving. The Quarterly Journal of Economics, 109(3): 659-684, 1994.

ANTUNES, A.; CAVALCANTI, T.; VILLAMIL, A.. The effect of financial repression and enforcement on entrepreneurship and economic development. Journal of Monetary Economics, 55: 278-297, 2008.

ANTUNES, A.; CAVALCANTI, T.; VILLAMIL, A.. The effects of credit subsidies on development. Economic Theory, 58(1): 1-30, 2014.

ARAÚJO, A.; FUNCHAL, B.. A nova Lei de Falências brasileira: primeiros impactos. Revista de economia política, 29(3): 191-212, 2009.

ASSUNÇÃO, J.. Eliminating entry barriers for the provision of banking services: Evidence from 'banking correspondents' in Brazil. Journal of Banking and Finance, 37(8): 2806-2811, 2013.

ASSUNÇÃO, J.; ALVES, L.. Restrições de crédito e decisões intra-familiares. Revista Brasileira de Economia. 61(2): 201-229, 2007.

ASSUNÇÃO, J.; SILVA, F.; BENMELECH, E.. Repossession and the democratization of credit. Working Paper 17.858, NBER, 2012.

BANERJEE, A.; NEWMAN, A.. Occupational choice and the process of development. The Journal of Political Economy, 101(2): 274-298, 1993.

BERRIEL, T.; ZILBERMAN, E.. Targeting the poor: a macroeconomic analysis of cash transfer programs. Texto para discussão 598, Departamento de Economia da PUC-Rio, 2011.

BUERA, F.; KABOSKI, J.; SHIN, Y.. Finance and development: a tale of two sectors. American Economic Review, 101(5): 1964-2002, 2011.

BUERA, F.; SHIN, Y.. Self-insurance vs. self-financing: A welfare analysis of persistence of shocks. Journal of Economic Theory, 146: 845-862, 2011. 
BUERA, F.; SHIN, Y.. Financial frictions and the persistence of history: a quantitative exploration. Journal of Political Economy, 121(2): 221-272, 2013.

CAGETTI, M.; DE NARDI, M.. Entrepreneurship, frictions and wealth. Journal of Political Economy, 114(5): 835-870, 2006.

CARVALHO, C.; PASCA, N.; SOUZA, L.; ZILBERMAN, E.. Macroeconomic effects of credit deepening in Latin America. 2014.

CAVALCANTI, V.. Tributos sobre a folha ou sobre o faturamento? Efeitos quantitativos para o Brasil. Revista Brasileira de Economia, 62(3): 249-261, 2008.

CIHÁK, M.; DEMIRGUÇ-KUNT, A.; FEYEN, E.; LEVINE, R.. Benchmarking Financial Systems around the World. Policy Research Working Paper 6175, World Bank, 2012.

CURTIS, C.. Economic reforms and the evolution of China's total factor productivity. Review of Economic Dynamics, 21(3): 225-245, 2016.

DABLA-NORRIS, E.; JI, Y.; TOWNSEND, R.; UNSAL, D.. Distinguishing constraints on financial inclusion and their impact on GDP, TFP, and inequality. 2015.

DEMIRGÜÇ-KUNT, A.; LEVINE, R.. Finance, Financial Sector Policies, and Long Run Growth. M. Spence Growth Commission Background Paper 11, World Bank, 2008.

ELLERY, R.; BUGARIN, M.. Previdência social e bem estar no Brasil. Revista Brasileira de Economia, 57(1): 27-57, 2003.

FERREIRA, F.; LANJOUW, P.; NERI, M.. A new poverty profile for Brazil using PPV, PNAD and census data. Texto para discussão 418, Department of Economics PUC-Rio. 2000.

GALE, D.; HELLWIG, M.. Incentive-compatible debt contracts: the oneperiod problem. The Review of Economic Studies, 52(4): 647-663, 1985.

GINÉ, X.; TOWNSEND, R.. Evaluation of financial liberalization: a general equilibrium model with constrained occupation choice. Journal of Development Economics, 74: 269-307, 2004.

GREEENWOOD, J.; SANCHEZ, J.; WANG, C.. Quantifying the impact of financial development on economic development. Review of Economic Dynamics, 16(1): 194-215, 2013.

GUERRIERI, V.; LORENZONI, G.. Credit crises, precautionary savings and the liquidity trap. Working Paper 17583, NBER, 2011. 
HEER, B.; MAUSSNER, A.. Dynamic general equilibrium modeling: computational methods and applications. Springer-Verlag, Berlin, 2009.

HSIEH, C.; KLENOW, P.. Misallocation and manufacturing TFP in China and India. The Quarterly Journal of Economics, 124(4):1403-1448, 2009.

ISSLER, J.; PIQUEIRA, N.. Estimating relative risk aversion, the discount rate, and the intertemporal elasticity of substitution in consumption for Brazil using three types of utility function. Brazilian Review of Econometrics, 20(2): 201-239, 2000.

JEONG, H.; TOWNSEND, R.. Growth and inequality: model evaluation based on an estimation-calibration strategy. Macroeconomic Dynamics, 12(supplement 2): 231-284, 2008.

KING, R.; LEVINE, R.. Finance and growth: Schumpeter might be right. The Quarterly Journal of Economics, 108(3): 717-737, 1993.

LEVINE, R.. Finance and Growth: Theory and Evidence. In: Aghion, P. and Durlauf, S. (eds.), Handbook of Economic Growth. Elsevier Science, The Netherlands, 2005.

LEVINE, R.; LOAYZA, N.; BECK, T.. Financial intermediation and growth: causality and causes. Journal of Monetary Economics, 46(1): 31-77, 2000.

LLOYD-ELLIS, H.; BERNHARDT, D.. Enterprise, inequality and economic development. Review of Economic Studies, 67: 147-168, 2000.

LUCAS, R.. On the size distribution of business firms. The Bell Journal of Economics, 9(2): 508-523, 1978.

MARTIN, A.; TADDEI, F.. International capital flows and credit market imperfections: a tale of two frictions. Journal of International Economics, 89(2): 441-452, 2013.

MENDONÇA, M.. O crédito imobiliário no Brasil e sua relação com a política monetária. Texto para discussão 1909, IPEA, 2013.

MIDRIGAN, V.; XU, D.. Finance and misallocation: evidence from plant-level data. American Economic Review, 104(2): 422-458, 2014.

MOLL, B.. Productivity losses from financial frictions: can self-financing undo capital misallocation? American Economic Review, 104(10): 3186-3221, 2014.

MOLL, B.; TOWNSEND, R.; ZHORIN, V.. Economic development and the equilibrium interaction of financial frictions. 2014.

MORA, M.. A evolução do crédito no Brasil entre 2003 e 2010. Texto para Discussão 2022, IPEA, 2015. 
MORANDI, L.; REIS, E.. Estoque de capital fixo no Brasil, 1950-2002. 2004.

NERI, M.. Determinantes do êxito empresarial dos conta-próprias: uma análise dinâmica. Boletim Conjuntural, IPEA, 1999.

QUADRINI, V.. Entrepreneurship, saving and social mobility. Review of Economic Dynamics, 3: 1-40, 2000.

RESTUCCIA, D.. Factor misallocation e development. Working paper 502, Department of Economics University of Toronto, 2013.

SALAMI, C.; FOCHEZATTO, A.. Avaliando os impactos de políticas tributárias sobre a economia brasileira com base em um modelo de equilíbrio geral de gerações sobrepostas. Revista Brasileira de Economia, 63(3): 299-314, 2009.

TAUCHEN, G.. Finite state Markov-chain approximations to univariate and vector autoregressions. Economic Letters, 20: 177-181, 1986.

TOWNSEND, R.. Optimal contracts and competitive markets with costly verification. Journal of Economic Theory, 21: 265-293, 1979. 
A

\section{Provas do capítulo 3}

\section{A.1) Proposição 1:}

No regime de poupança, a demanda ótima de capital e de trabalho do empresário do tipo $(b, z)$ são dadas por:

$$
\begin{gathered}
k^{*}(b, z)=\min \left(b, \tilde{k^{s}}(z)\right) \\
l^{*}(b, z)=\left[\frac{z(1-\alpha)(1-v)}{w}\right]^{\frac{1}{\alpha(1-v)+v}} k^{*}(b, z)^{\frac{\alpha(1-v)}{\alpha(1-v)+v}}
\end{gathered}
$$

Onde $\tilde{k^{s}}(z)=\left[\frac{\alpha w(1-p)}{(1-\alpha)\left(r^{d}+(1-p) \delta-p \eta(1-\delta)+p\right)}\right]^{\frac{\alpha(1-v)+v}{v}}\left(\frac{(1-v)(1-\alpha) z}{w}\right)^{\frac{1}{v}}$ é a

demanda irrestrita de capital no regime de poupança.

Prova:

Para qualquer nível de capital, a demanda ótima de trabalho do empresário é dada pela condição de primeira ordem do problema (6):

$$
l=\left[\frac{z(1-\alpha)(1-v)}{w}\right]^{\frac{1}{\alpha(1-v)+v}} k^{\frac{\alpha(1-v)}{\alpha(1-v)+v}}
$$

Substituindo (A-3) em (6) e rearranjando os termos, obtemos o seguinte problema:

$$
\begin{aligned}
& \pi^{s}(b, z)=\max _{k}(1-p)\left(\left(\frac{(1-v)(1-\alpha)}{w} z\right)^{\frac{1}{\alpha(1-v)+v}} w \frac{v+\alpha(1-v)}{(1-v)(1-\alpha)} k^{\frac{\alpha(1-v)}{v+\alpha(1-v)}}-\delta k+k\right) \\
& +p \eta(1-\delta) k+\left(1+r^{d}\right)(b-k) \\
& \text { s.a. } k \leq b
\end{aligned}
$$

Resolvendo este problema sem impor a restrição de riqueza, obtemos a demanda de capital irrestrita:

$$
\tilde{k^{s}}(z)=\left[\frac{\alpha w(1-p)}{(1-\alpha)\left(r^{d}+(1-p) \delta-p \eta(1-\delta)+p\right)}\right]^{\frac{\alpha(1-v)+v}{v}}\left(\frac{(1-v)(1-\alpha) z}{w}\right)^{\frac{1}{v}}
$$


Desde que $\pi^{s}(b, z)$ é crescente em $k$ para $k \leq k^{s}(z)$, a demanda ótima de capital para o problema restrito é dada por:

$$
k^{*}(b, z)=\min \left(b, \tilde{k}^{s}(z)\right)
$$

\section{A.2) Proposição 2:}

No regime de crédito, a inadimplência ocorre para empresários altamente alavancados. Em particular, existe um limite de inadimplência dado por:

$$
\bar{\lambda}=\frac{1+\mathrm{r}^{\mathrm{d}}}{1+\mathrm{r}^{\mathrm{d}}-\eta(1-\delta)}
$$

Este limite depende dos parâmetros $\eta$ e $\delta$ e da taxa de depósito endógena $r^{d}$. Para um empresário que opera uma firma com taxa de alavancagem $\tilde{\lambda}$ temos:

a) Se $\tilde{\lambda} \leq \bar{\lambda}$, a inadimplência nunca ocorre e a taxa de empréstimo é dada por $r^{l}=r^{d}$.

b) Se $\tilde{\lambda}>\bar{\lambda}$, a inadimplência ocorre quando a produção falha e a taxa de empréstimo é crescente em $\tilde{\lambda}$ e dada por:

$$
r^{l}=\frac{1+r^{d}+p \chi-p \eta(1-\delta)-p\left(1+r^{d}\right) \tilde{\lambda}^{-1}}{1-p}-1
$$

Prova:

Primeiro iremos calcular o limite de inadimplência $\bar{\lambda}$. Para empresários sem risco de inadimplência, o capital recuperado quando a produção falha mais o valor do colateral incluindo juros devem ser maiores do que o valor de face do empréstimo. Neste caso:

$$
\eta(1-\delta) k+\left(1+r^{d}\right)(b-\psi) \geq \Omega
$$

Quando a condição (A-9) é satisfeita, a condição de lucro zero do banco (3-17) implica em:

$$
\Omega=\left(1+r^{d}\right) k
$$

Substituindo (A-10) em (A-9) obtemos:

$$
\eta(1-\delta) k+\left(1+r^{d}\right)(b-\psi) \geq\left(1+r^{d}\right) k
$$


Usando a definição de taxa de alavancagem de (3-10), (A-11) pode ser escrita como:

$$
\tilde{\lambda}=\frac{k}{b-\psi} \leq \frac{1+\mathrm{r}^{\mathrm{d}}}{1+\mathrm{r}^{\mathrm{d}}-\eta(1-\delta)}
$$

Assim o limite de inadimplência é dado por:

$$
\bar{\lambda}=\frac{1+\mathrm{r}^{\mathrm{d}}}{1+\mathrm{r}^{\mathrm{d}}-\eta(1-\delta)}
$$

Note que o "limited commitment" determina a restrição: $\tilde{\lambda} \leq \lambda$. Para obter uma taxa de inadimplência positiva para o modelo, nós impomos:

$$
\frac{1+\mathrm{r}^{\mathrm{d}}}{1+\mathrm{r}^{\mathrm{d}}-\eta(1-\delta)}<\lambda
$$

Isto determina o intervalo de taxas de juros endógenas:

$$
r^{d}>\frac{\eta(1-\delta) \lambda}{\lambda-1}-1
$$

Agora, iremos computar a taxa de empréstimo para os empresários com taxa de alavancagem $\tilde{\lambda}$. Se $\tilde{\lambda} \leq \bar{\lambda}$, os empresários não ficam inadimplentes. Como foi mostrado acima, a taxa de empréstimo é igual à taxa de depósito, $r^{l}=r^{d}$. Se $\tilde{\lambda}^{2} \bar{\lambda}$, o empresário fica inadimplente quando a produção falha e a condição (A-9) é violada. Neste caso, a condição de lucro zero do banco (3-17) implica em:

$$
\Omega=\frac{\left(1+r^{d}\right) k+p \chi k-p \eta(1-\delta) k-p\left(1+r^{d}\right)(b-\psi)}{1-p}
$$

A taxa de empréstimo definida em (3-9) é dada por:

$$
r^{l}=\frac{1+r^{d}+p \chi-p \eta(1-\delta)-p\left(1+r^{d}\right) \tilde{\lambda}^{-1}}{1-p}-1
$$

A.3) Proposição 3:

No regime de crédito, para empresários do tipo $(b, z)$, definimos a taxa de alavancagem ótima por: $\lambda^{*}(b, z)$ e a demanda por capital ótima por: $k^{*}(b, z)$. Existe um nível crítico de riqueza $\bar{b}(z)$ tal que:

a) Se $\psi \leq b<\bar{b}(z)$ então:

$$
\bar{\lambda}<\lambda^{*}(b, z) \leq \lambda
$$




$$
k^{*}(b, z)=\min \left(\lambda(b-\psi), \tilde{k^{h}}(z)\right)
$$

Onde:

$$
\tilde{k^{h}}(z)=\left[\frac{(1-p) \alpha w}{\left(r^{d}+p \chi+(1-p) \delta-p \eta(1-\delta)+p\right)(1-\alpha)}\right]^{\frac{\alpha(1-v)+v}{v}}\left(\frac{(1-v)(1-\alpha) z}{w}\right)^{\frac{1}{v}} .
$$

b) Se $b \leq \bar{b}(z)$ então:

$$
\begin{gathered}
\lambda^{*}(b, z) \leq \bar{\lambda} \\
k^{*}(b, z)=\min \left(\bar{\lambda}(b-\psi), \tilde{k}^{l}(z)\right)
\end{gathered}
$$

Onde $\tilde{k}^{l}(z)=\left[\frac{(1-p) \alpha w}{\left(r^{d}+(1-p) \delta-p \eta(1-\delta)+p\right)(1-\alpha)}\right]^{\frac{\alpha(1-v)+v}{v}}\left(\frac{(1-v)(1-\alpha) z}{w}\right)^{\frac{1}{v}}$.

Prova:

No regime de crédito, os empresários resolvem o problema (3-13) sujeito à condição de lucro zero do banco (3-17). Este problema é não-convexo dado que na região de alta alavancagem o banco monitora quando a produção falha, o que eleva o custo do capital. Para obter uma solução, o problema (3-13) é convertido em dois subproblemas convexos. No primeiro problema o empresário não fica inadimplente e a taxa de alavancagem é restrita por $\tilde{\lambda} \leq \bar{\lambda}$. No segundo problema, o empresário fica inadimplente quando a produção falha e a taxa de alavancagem é restrita por $\tilde{\lambda} \leq \lambda$. A função riqueza para cada subproblema é convexa. A riqueza de final de período mais alta que pode ser obtida pelo empresário é o envelope superior das duas funções riqueza, e ele não é convexo. Abaixo, primeiro obtemos a solução para cada subproblema e depois obtemos a solução do problema original.

O primeiro subproblema

Neste subproblema, o empresário não fica inadimplente. Como mostrado na prova da proposição 2 temos que $\Omega=\left(1+r^{d}\right) k$. Substituindo a expressão para $\Omega$ no problema (3-13) e rearranjando os termos, obtemos: 


$$
\begin{aligned}
& \pi^{l}(b, z)=\max _{k, l}(1-p)\left(z\left(k^{\alpha} l^{1-\alpha}\right)^{1-v}-w l-\delta k-r^{d} k\right)+p \eta(1-\delta) k \\
& +\left(1+r^{d}\right)(b-\psi)-p\left(1+r^{d}\right) k \\
& \text { s.a. } \quad k \leq \bar{\lambda}(b-\psi)
\end{aligned}
$$

A solução deste problema, sem impor a restrição sobre o capital, determina o nível de capital irrestrito:

$$
\tilde{k}^{l}(z)=\left[\frac{(1-p) \alpha w}{\left(r^{d}+(1-p) \delta-p \eta(1-\delta)+p\right)(1-\alpha)}\right]^{\frac{\alpha(1-v)+v}{v}}\left(\frac{(1-v)(1-\alpha) z}{w}\right)^{\frac{1}{v}}
$$

A demanda ótima de capital é dada por:

$$
k^{*}(b, z)=\min \left(\bar{\lambda}(b-\psi), \tilde{k}^{l}(z)\right)
$$

A demanda ótima de trabalho é dada por:

$$
l^{*}(b, z)=\left[\frac{z(1-\alpha)(1-v)}{w}\right]^{\frac{1}{\alpha(1-v)+v}} k^{*}(b, z)^{\frac{\alpha(1-v)}{\alpha(1-v)+v}}
$$

Substituindo (A-24) e (A-25) em (A-22) obtemos a função riqueza:

$$
\begin{aligned}
& \pi^{l}(b, z)=(1-p)\left(z\left(k^{* \alpha} l^{*_{1}-\alpha}\right)^{1-v}-w l^{*}-\delta k^{*}-r^{d} k^{*}\right)+p \eta(1-\delta) k^{*} \\
& +\left(1+r^{d}\right)(b-\psi)-p\left(1+r^{d}\right) k^{*}
\end{aligned}
$$

O segundo subproblema

Neste subproblema, o empresário fica inadimplente quando a produção falha. Como mostrado na prova da proposição 2, temos que neste caso:

$$
\Omega=\frac{\left(1+r^{d}\right) k+p \chi k-p \eta(1-\delta) k-p\left(1+r^{d}\right)(b-\psi)}{1-p}
$$

Substituindo (A-27) em (3-13) obtemos:

$$
\begin{aligned}
& \pi^{h}(b, z)=\max _{k, l}(1-p)\left(z\left(k^{\alpha} l^{1-\alpha}\right)^{1-v}-w l+(1-\delta) k+\left(1+r^{d}\right)(b-\psi)\right) \\
& -\left(\left(1+r^{d}\right) k+p \chi k-p \eta(1-\delta) k-p\left(1+r^{d}\right)(b-\psi)\right) \\
& \text { s.a. } \quad k \leq \lambda(b-\psi)
\end{aligned}
$$

Resolvendo o problema sem considerar a restrição, obtemos o nível de capital irrestrito:

$$
\tilde{k^{h}}(z)=\left[\frac{(1-p) \alpha w}{\left(r^{d}+p \chi+(1-p) \delta-p \eta(1-\delta)+p\right)(1-\alpha)}\right]^{\frac{\alpha(1-v)+v}{v}}\left(\frac{(1-v)(1-\alpha) z}{w}\right)^{\frac{1}{v}}
$$


A demanda ótima de capital é dada por:

$$
k^{*}(b, z)=\min \left(\lambda(b-\psi), \tilde{k^{h}}(z)\right)
$$

A demanda ótima de trabalho é dada por:

$$
l^{*}(b, z)=\left[\frac{z(1-\alpha)(1-v)}{w}\right]^{\frac{1}{\alpha(1-v)+v}} k^{*}(b, z)^{\frac{\alpha(1-v)}{\alpha(1-v)+v}}
$$

Substituindo (A-30) e (A-31) em (A-28) obtemos a função riqueza:

$$
\begin{aligned}
& \pi^{h}(b, z)=(1-p)\left(z\left(k^{* \alpha} l^{*_{1-\alpha}}\right)^{1-v}-w l^{*}+(1-\delta) k^{*}+\left(1+r^{d}\right)(b-\psi)\right) \\
& -\left(\left(1+r^{d}\right) k^{*}+p \chi k^{*}-p \eta(1-\delta) k^{*}-p\left(1+r^{d}\right)(b-\psi)\right)
\end{aligned}
$$

A solução do problema original é dada pelo máximo dos dois subproblemas:

$$
\pi^{C}(b, z)=\max \left\{\pi^{l}(b, z), \pi^{h}(b, z)\right\}
$$

Dabla_Norris e outros (2015) demonstram que $\pi^{l}(b, z)$ e $\pi^{h}(b, z)$ são côncavas e crescentes em $b$, e que existe uma única interseção das duas curvas, o que define o nível crítico de riqueza $\bar{b}(z)$. Quando $b$ é menor do que $\bar{b}(z)$, temos que $\pi^{l}(b, z)<\pi^{h}(b, z)$ e o empresário escolhe uma alta alavancagem. Caso contrário, o empresário escolhe baixa alavancagem. 


\section{B \\ Método de solução numérica do modelo do capítulo 4}

Para resolver o modelo do capítulo 4, nós utilizamos o método de elaborar “palpites” sobre o caminho finito no tempo para os preços dos fatores. Este método pode ser aplicado neste caso dado que o modelo não possui incerteza agregada. O método considera a transição para um equilíbrio estacionário. Para a computação supomos que o novo equilíbrio estacionário é alcançado após um período de tempo de $\mathrm{T}$ anos. Além disso, nós calculamos separadamente o equilíbrio de estado estacionário para o período $\mathrm{t} \geq \mathrm{T}$. Nós também conhecemos a distribuição de riqueza do período inicial t $=1$, que é obtida do equilíbrio de estado estacionário inicial. Então sabemos o estoque de capital e o preço dos fatores do período $\mathrm{t}=1$ e do período $\mathrm{t}=\mathrm{T}$. Para computar as funções políticas durante a transição precisamos saber o caminho no tempo dos preços dos fatores. Nós começamos com um palpite inicial do caminho no tempo dos preços dos fatores e computamos as funções de decisões. Depois utilizando a distribuição inicial e as funções de decisão computadas podemos computar o caminho no tempo implicado dos preços dos fatores. Se o palpite inicial dos preços dos fatores é diferente dos valores implicados pela simulação, nós atualizamos o palpite de acordo com esta diferença. $\mathrm{O}$ algoritmo é descrito pelos seguintes passos ${ }^{45}$ :

1) Escolha o número de períodos de transição T. Ele tem que ser longo o suficiente para que o modelo alcance um novo estado estacionário.

2) Forneça um palpite para as sequências de salários e taxas de juros do período t= 0 até o período $\mathrm{t}=\mathrm{T}$.

3) Compute as funções valor no tempo T. Itere as funções valor para trás do período $\mathrm{t}=\mathrm{T}$ até $\mathrm{t}=0$. Simule uma grande quantidade de indivíduos por $\mathrm{T}$ períodos usando as funções política e a distribuição inicial de ativos e habilidades. Compute a demanda agregada de trabalho das firmas e a oferta agregada de trabalho para cada período. Atualize a sequência de salários durante a transição e repita este passo até que o mercado de trabalho esteja em equilíbrio em cada período.

\footnotetext{
${ }^{45} \mathrm{O}$ algoritmo segue Heer e Maussner,2009 com algumas pequenas modificações.
} 
4) Depois de obter o equilíbrio no mercado de trabalho, compute novamente a função valor para o período T. Itere para trás a função valor do período t=T até $\mathrm{t}=0$ e simule uma grande quantidade de indivíduos. Obtenha a demanda agregada de capital das firmas e a oferta de capital. Atualize a sequência de taxas de juros e repita este passo até que o mercado de capitais esteja em equilíbrio em cada período.

5) Repita os passos 3 e 4 até que os mercados de trabalho e capital estejam ambos em equilíbrio em cada período. 


\section{C}

\section{Construção do índice de riqueza}

Neste Anexo descrevemos a metodologia de construção do índice de riqueza e da variável empresário. Estas variáveis foram utilizadas na estimação de parte dos parâmetros do modelo do capítulo 5. Para construir o índice, utilizamos a metodologia descrita em Assunção e Alves (2007) com pequenas alterações. Os dados utilizados foram obtidos na Pesquisa Nacional por Amostra de Domicílios (PNAD).

Nós utilizamos os dados da pesquisa de 2004. A informação sobre riqueza é construída a partir de características disponíveis ao nível do domicílio do chefe da família. Neste texto, consideramos como empresários somente os chefes de família cuja ocupação, segundo a PNAD, é de empregador. Os trabalhadores por conta própria não são considerados empresários neste texto e sim trabalhadores. No modelo utilizado, todos os trabalhadores recebem o salário médio da economia e a remuneração dos empresários é maior do que este salário. Neste caso, nos dados, não consideramos os autônomos como empresários, pois este grupo possui uma grande quantidade de indivíduos que recebem menos do que um salário mínimo e na verdade estão subempregados. Considerá-los como empresários geraria uma grande distorção na análise. Assunção e Alves (2007) argumentam que a atividade por conta-própria no Brasil está associada à informalidade e a pobreza. Segundo Ferreira e outros(2000), a maioria dos chefes de família, que estão abaixo da linha de pobreza, é trabalhador por conta-própria. Segundo Neri (1999) existem diferenças significativas no Brasil entre trabalhadores por contaprópria e empregadores.

A PNAD contém uma série de variáveis que podem ser combinadas para construir um índice de riqueza. Ela possui informações referentes à estrutura física dos domicílios (material das paredes, da cobertura e número de cômodos), ao acesso a serviços urbanos (água, esgoto, luz, coleta de lixo e telefone), à posse de bens duráveis (fogão, geladeira e filtro de água) e ao número de empregados domésticos. Possui também informações sobre se a família é proprietária do 
imóvel onde reside e/ou proprietária de algum outro imóvel, se ela recebe doações de não morador e se recebe juros de aplicações financeiras.

Foram escolhidas 13 variáveis dentro do conjunto de variáveis com as características descritas acima. O índice de riqueza foi construído por meio da análise dos componentes principais, considerando a matriz de correlação dessas variáveis selecionadas. Esse índice é obtido como a combinação linear com maior capacidade explicativa sobre a variância dos indicadores considerados. O índice de riqueza obtido não apresenta unidade de medida.

A tabela C.1 apresenta os autovalores da matriz de correlação e o percentual explicado por cada componente principal. O primeiro componente principal responde por cerca de 25\% da variância total do conjunto de indicadores. O segundo componente principal representa cerca de 11\% dessa variância. Desse modo, resolvemos representar a riqueza por meio do primeiro componente principal.

Tabela C.1: Análise de componentes principais para construção do índice de riqueza.

\begin{tabular}{|c|c|c|c|c|}
\hline Componente & Autovalor & Diferença & Proporção & Acumulado \\
\hline 1 & 3,31 & 1,99 & 0,25 & 0,25 \\
\hline 2 & 1,31 & 0,11 & 0,10 & 0,36 \\
\hline 3 & 1,21 & 0,17 & 0,09 & 0,45 \\
\hline 4 & 1,03 & 0,10 & 0,08 & 0,53 \\
\hline 5 & 0,94 & 0,03 & 0,07 & 0,60 \\
\hline 6 & 0,90 & 0,12 & 0,07 & 0,67 \\
\hline 7 & 0,79 & 0,04 & 0,06 & 0,73 \\
\hline 8 & 0,75 & 0,08 & 0,06 & 0,79 \\
\hline 9 & 0,67 & 0,06 & 0,05 & 0,84 \\
\hline 10 & 0,62 & 0,05 & 0,05 & 0,89 \\
\hline 11 & 0,56 & 0,05 & 0,04 & 0,93 \\
\hline 12 & 0,51 & 0,12 & 0,04 & 0,97 \\
\hline 13 & 0,39 & & 0,03 & 1,00 \\
\hline
\end{tabular}

A tabela C.2 apresenta as variáveis utilizadas para a construção do índice de riqueza e suas respectivas ponderações. 
Tabela C.2: Variáveis utilizadas e respectivos pesos.

\begin{tabular}{|l|c|}
\hline \multicolumn{1}{|c|}{ Variável } & Peso \\
\hline O tipo de domicílio é casa ou apartamento? & 0,04 \\
\hline Paredes externas predominantemente de alvenaria? & 0,14 \\
\hline Telhado predominantemente de telha ou laje de concreto? & 0,11 \\
\hline Número de cômodos no domicílio & 0,11 \\
\hline Este domicílio é próprio (já pago ou ainda pagando)? & 0,01 \\
\hline Água proveniente de rede geral de distribuição & 0,21 \\
\hline Possui banheiro de uso exclusivo do domicílio? & 0,20 \\
\hline Escoadouro do banheiro é feito através de uma rede coletora de & 0,16 \\
\hline esgoto? & 0,21 \\
\hline O lixo é coletado? & 0,19 \\
\hline Tem iluminação elétrica? & 0,13 \\
\hline Tem fogão? & 0,08 \\
\hline Este domicílio tem algum tipo de filtro de água? & 0,20 \\
\hline Este domicílio tem geladeira? & \\
\hline
\end{tabular}

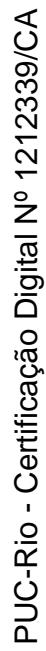




\section{Identificação do modelo do capítulo 5}

Neste Anexo descrevemos o procedimento de identificação do modelo utilizado no capítulo 5, para poder estimar os parâmetros tecnológicos. A metodologia de identificação que utilizamos neste trabalho está baseada em Jeong e Townsend (2008). No setor sem acesso ao crédito, o problema de maximização do lucro do empresário é dado por:

$$
\begin{aligned}
& \max _{k, l}\{f(k, l)-w l-k-x\} \\
& \text { s.a. } 0 \leq k \leq b-x
\end{aligned}
$$

Onde a função de produção é dada por:

$$
f\left(k_{t}, l_{t}\right)=\alpha k_{t}-\frac{\beta}{2} k_{t}^{2}+\xi l_{t}-\frac{\rho}{2} l_{t}^{2}+\sigma_{t} k_{t}
$$

Calculando a condição de primeira ordem para o trabalho $l$, no problema acima, e rearranjando os termos, obtemos:

$$
l^{s}(b, x, w)=\frac{\sigma k^{s}(b, x, w)+(\xi-w)}{\rho}
$$

Substituindo (D-3) e (D-4) em (D-1) e rearranjando os termos, obtemos a seguinte expressão para a função lucro:

$$
\pi(b, x, w)=C_{0}(w)+C_{1}(w) k+C_{2} k^{2}-x
$$

Onde:

$$
\begin{aligned}
& C_{0}(w)=\frac{(\xi-w)^{2}}{2 \rho} \\
& C_{1}(w)=\alpha-1+\frac{\sigma(\xi-w)}{\rho} \\
& C_{2}=\frac{1}{2}\left(\frac{\sigma^{2}}{\rho}-\beta\right)
\end{aligned}
$$

Neste caso, a função lucro pode ser expressa, na forma reduzida, como um polinômio do segundo grau na demanda de capital $k$.

Se os empresários são restritos, a demanda de capital $k$ depende da riqueza $b$, do salário $w$ e também dos parâmetros tecnológicos $(\delta, \beta, \xi, \rho, \sigma)$. Se os empresários 
não são restritos pela riqueza, a condição de primeira ordem para o capital $k$ no problema (D-1) é dada por:

$$
\alpha-\beta k_{t}+\sigma_{t}-1=0
$$

Substituindo (D-4) em (D-7) obtemos a demanda de capital irrestrita $\mathrm{k}^{*}$ :

$$
k^{*}=\frac{C_{1}(w)}{-2 C_{2}}
$$

Devemos lembrar que o determinante principal da escolha ocupacional é a função custo de instalação crítico $z^{s}(b, w)$ que é dada pelo custo de instalação $x$ que iguala o lucro ao salário. Definimos $x^{*}$ como o custo de instalação máximo tal que para todo $x>x^{*}$ o indivíduo nunca será um empresário. Além disso, definimos como $b^{*}$ o nível de riqueza mínimo de um empresário com custo $x^{*}$ tal que ele é irrestrito. Por último, definimos $\tilde{b}$ tal que $z^{s}(\tilde{b}, w)=\tilde{b}$. Então para $b<\tilde{b}$ temos $z^{s}(b, w)=b$ pois a riqueza do empresário não pode ser menor do que o custo de instalação.

Dado que $z^{s}(b, w)$ é o nível de $x$ que iguala o lucro do empresário ao salário, de (D5) temos:

$$
C_{0}(w)+C_{1}(w) k+C_{2} k^{2}-z=w
$$

Para o empresário restrito, a demanda de capital é dada por:

$$
k=b-x
$$

Substituindo (D-10) em (D-9) obtemos:

$$
C_{0}(w)+C_{1}(w)(b-z)+C_{2}(b-z)^{2}-z-w=0
$$

A solução para z é dada por:

$$
z=b+\frac{C_{1}(w)+1-\sqrt{\left(C_{1}(w)+1\right)^{2}-4 C_{2}\left(C_{0}(w)-b-w\right)}}{2 C_{2}}
$$

Desse modo, a função z é dada por:

$$
\begin{aligned}
z^{s}(b, w) & =x^{*}(w), \quad \text { se } b \geq b^{*}(w) \\
& =b+\frac{C_{1}(w)+1-\sqrt{\left(C_{1}(w)+1\right)^{2}-4 C_{2}\left(C_{0}(w)-b-w\right)}}{2 C_{2}}, \text { se } \tilde{b}(w) \leq b<b^{*}(w) \\
& =b, \quad \text { se } b<\tilde{b}(w)
\end{aligned}
$$

Onde:

$$
\tilde{b}(w)=C_{0}(w)-w
$$




$$
\begin{aligned}
x^{*}(w)=\tilde{b}(w)-\frac{C_{1}(w)^{2}}{4 C_{2}} \\
b^{*}(w)=x^{*}(w)-\frac{C_{1}(w)}{2 C_{2}}
\end{aligned}
$$

Então, os três coeficientes da função lucro $\mathrm{C}_{0}(\mathrm{w}), \mathrm{C}_{1}(\mathrm{w})$ e $\mathrm{C}_{2}$ determinam a escolha ocupacional. Neste caso, a função log verossimilhança com os parâmetros tecnológicos é equivalente à função log verossimilhança com os parâmetros $\mathrm{C}_{0}(\mathrm{w}), \mathrm{C}_{1}(\mathrm{w})$ e $\mathrm{C}_{2}$ :

$$
\log L(\alpha, \beta, \xi, \rho, \sigma, m ; w)=\log L\left(C_{0}, C_{1}, C_{2}, m ; w\right)
$$

Assim, somente três dos cinco parâmetros da função de produção podem ser identificados se utilizamos um único salário w. Contudo, utilizando variação do salário ao longo do tempo, podemos identificar todos os cinco parâmetros tecnológicos. Para tanto, utilizamos a variação do salário entre 2004 e 2005. Dado o salário em 2004, w ${ }^{2004}$, o custo de instalação crítico z e a função log verossimilhança são caracterizados pelos três coeficientes $\mathrm{C}_{0}\left(\mathrm{w}^{2004}\right), \mathrm{C}_{1}\left(\mathrm{w}^{2004}\right)$ e $\mathrm{C}_{2}$. De forma similar, dado $\mathrm{w}^{2005}, \mathrm{z}$ e a função log verossimilhança são determinadas por $\mathrm{C}_{0}\left(\mathrm{w}^{2005}\right), \mathrm{C}_{1}\left(\mathrm{w}^{2005}\right)$ e $\mathrm{C}_{2}$. A função log verossimilhança, considerando os dois anos, é dada por:

$$
\log L\left(C_{0}^{2004}, C_{1}^{2004}, C_{2}, m ; w^{2004}\right)+\log L\left(C_{0}^{2005}, C_{1}^{2005}, C_{2}, m ; w^{2005}\right)
$$

Onde:

$$
C_{0}^{2004}=C_{0}\left(w^{2004}\right), C_{1}^{2004}=C_{1}\left(w^{2004}\right), C_{0}^{2005}=C_{0}\left(w^{2005}\right), C_{1}^{2005}=C_{1}\left(w^{2005}\right),
$$

Então nós estimamos $C_{0}^{2004}, C_{1}^{2004}, C_{0}^{2005}, C_{1}^{2005}$ e $C_{2}$ por máxima verossimilhança utilizando (D-18). A partir dos parâmetros estimados recuperamos os parâmetros tecnológicos. Dividindo $C_{0}^{2004}$ por $C_{0}^{2005}$ obtemos $\xi$ :

$$
\xi=\frac{w^{2005} \sqrt{C_{0}^{2004}}-w^{2004} \sqrt{C_{0}^{2005}}}{\sqrt{C_{0}^{2004}}-\sqrt{C_{0}^{2005}}}
$$

Substituindo (D-20) em (D-6a), para $w=w^{2004}$, obtemos $\rho$ :

$$
\rho=\frac{1}{2}\left(\frac{w^{2005}-w^{2004}}{\sqrt{C_{0}^{2004}}-\sqrt{C_{0}^{2005}}}\right)^{2}
$$

De (D-6b) temos: 


$$
C_{1}^{2005}-C_{1}^{2004}=\frac{\sigma\left(\xi-w^{2005}\right)}{\rho}-\frac{\sigma\left(\xi-w^{2004}\right)}{\rho}
$$

Substituindo (D-21) em (D-22) obtemos $\sigma$ :

$$
\sigma=\frac{1}{2} \frac{\left(w^{2005}-w^{2004}\right)\left(C_{1}^{2004}-C_{1}^{2005}\right)}{\left(\sqrt{C_{0}^{2004}}-\sqrt{C_{0}^{2005}}\right)^{2}}
$$

Substituindo (D-20), (D-21) e (D-23) em (D-6b), para $w=w^{2004}$, obtemos $\alpha$ :

$$
\alpha=1+\frac{C_{1}^{2005} \sqrt{C_{0}^{2004}}-C_{1}^{2004} \sqrt{C_{0}^{2005}}}{\sqrt{C_{0}^{2004}}-\sqrt{C_{0}^{2005}}}
$$

Por último, substituindo (D-21) e (D-23) em (D-6c) obtemos $\beta$ :

$$
\beta=\frac{1}{2}\left(\frac{C_{1}^{2004}-C_{1}^{2005}}{\sqrt{C_{0}^{2004}}-\sqrt{C_{0}^{2005}}}\right)^{2}-2 C_{2}
$$

O suporte da variável aleatória custo de instalação $x$ é o intervalo [0,1]. Neste caso, $\tilde{b}$ e ${ }^{*}$ devem satisfazer as seguintes restrições:

$0 \leq \tilde{b}\left(w^{t}\right) \leq 1$

$0 \leq x^{*}\left(w^{t}\right) \leq 1$

Isto implica nas seguintes restrições sobre os parâmetros:

$$
\begin{aligned}
C_{0}^{t}-w^{t} & \geq 0 \\
C_{0}^{t}-w^{t}-\frac{\left(C_{1}^{t}\right)^{2}}{4 C_{2}} & \leq 1 \quad t=2004,2005
\end{aligned}
$$

Além disso, dado que z é crescente e côncava em b, temos as seguintes restrições:

$$
\begin{aligned}
& \tilde{b}\left(w^{t}\right) \leq x^{*}\left(w^{t}\right) \\
& x^{*}\left(w^{t}\right) \leq b^{*}\left(w^{t}\right)
\end{aligned}
$$

Isto implica nas restrições:

$$
\begin{aligned}
& C_{2} \leq 0 \\
& C_{1}^{t} \geq 0 \quad t=2004,2005
\end{aligned}
$$

As restrições de desigualdade (D-26), (D-27), (D-28) e (D-29) são levadas em consideração na estimação. 